\title{
Turkey: Financial System Stability Assessment
}

This Financial System Stability Assessment on Turkey was prepared by a staff team of the International Monetary Fund and the World Bank as background documentation for the periodic consultation with the member country. It is based on the information available at the time it was completed on May 3, 2007. The views expressed in this document are those of the staff team and do not necessarily reflect the views of the government of Turkey or the Executive Board of the IMF.

The policy of publication of staff reports and other documents by the IMF allows for the deletion of market-sensitive information.

To assist the IMF in evaluating the publication policy, reader comments are invited and may be sent by e-mail to publicationpolicy@imf.org.

Copies of this report are available to the public from

International Monetary Fund $\bullet$ Publication Services

700 19th Street, N.W. • Washington, D.C. 20431

Telephone: (202) 6237430 • Telefax: (202) 6237201

E-mail: publications@imf.org • Internet: http://www.imf.org

Price: $\$ 18.00$ a copy

\section{International Monetary Fund}

Washington, D.C. 



\title{
INTERNATIONAL MONETARY FUND
}

\author{
TURKEY
}

\section{Financial System Stability Assessment}

\section{Prepared by the Monetary and Capital Markets and European Departments}

\author{
Approved by Axel Bertuch-Samuels and Michael Deppler
}

May 3, 2007

This Financial System Stability Assessment (FSSA) is based on work of the Financial Sector Assessment Program (FSAP) team, which visited Turkey in April and September 2006 and March 2007. The FSAP findings were also discussed with the authorities during a program review mission in October 2006 and the Article IV consultation mission in March 2007.

The FSAP team comprised, from the IMF side, Messrs. Enoch (Mission Chief, IMF), Hardy (Deputy Mission Chief, IMF), Cortavarria, Keller, Kunzel, Lee, and Surti, and Mmes. Holland, Mitchell-Casselle, Oulidi, and Rota (Administrative Assistant). Staff from the World Bank included Messrs. Hanson (Mission Chief, World Bank), Byskov, Endo, Keppler, Lester, Vittas, and Mmes. Annamalai and Marcus; Mr. Dankers (Netherlands Authority for Financial Markets, Securities Regulation); Mr. Demuynck (French Commission Bancaire, Stress Testing); Mr. Jaffee (University of California, Berkeley, Housing Sector); Mr. Lind (Swedish Riksbank, Banking Supervision); and Ms. Nieto (Bank of Spain, Banking Supervision). The FSAP team received excellent cooperation from the authorities and market participants, and a number of the recommendations made during the missions have already been implemented.

The main findings of the FSAP are that:

- The banking system has strengthened markedly over the past five years, and lending to the private sector is replacing the financing of government as the core activity. Foreign direct investment is contributing to the transformation of the financial sector.

- Financial sector vulnerabilities remain, in part reflecting macroeconomic vulnerabilities, the rapid expansion in credit, and intensified competition among banks.

- A generally high level of observance of financial sector standards has been achieved, and the authorities are undertaking further enhancements. Nonetheless, they still need to demonstrate that enforcement and, if necessary, intervention will be prompt and vigorous.

- Contingent on sustained macroeconomic stabilization and further institutional reforms, the financial system and especially nonbank financial institutions should continue to develop rapidly, boosting economic growth.

The main authors of this FSSA are Messrs. Enoch and Hardy, with contributions from the rest of the FSAP team. FSAPs are designed to assess the stability of the financial system as a whole and not that of individual institutions. They have been developed to help countries identify and remedy weaknesses in their financial sector structure, thereby enhancing their resilience to macroeconomic shocks and cross-border contagion. FSAPs do not cover risks that are specific to individual institutions such as asset quality, operational or legal risks, or fraud. 


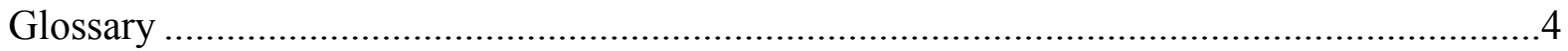

Executive Summary ..................................................................................................

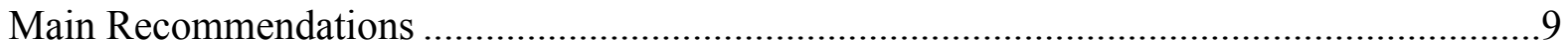

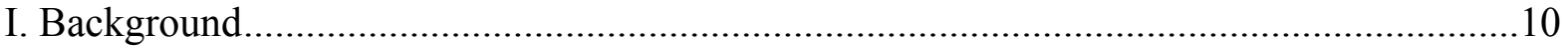

A. Macroeconomic Developments and Vulnerabilities ........................................ 10

B. Trends in the Financial System .............................................................. 10

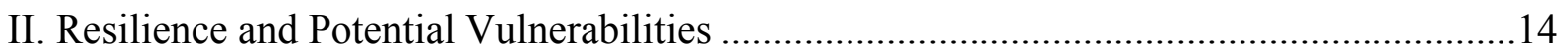

A. Trends in Financial Soundness Indicators ...................................................... 15

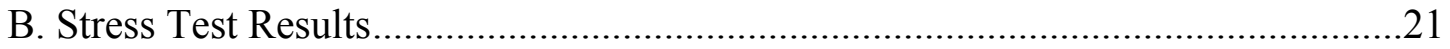

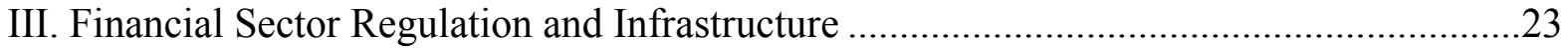

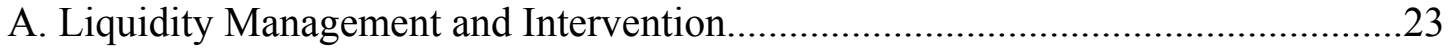

B. The Regulatory and Supervisory Framework .................................................24

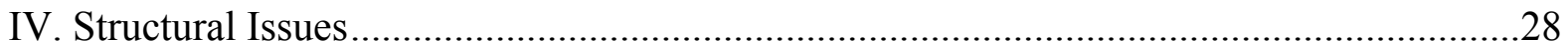

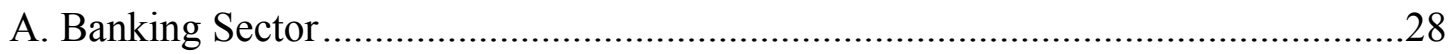

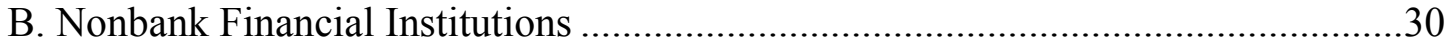

C. Credit Information and the Legal Framework.................................................. 31

Tables

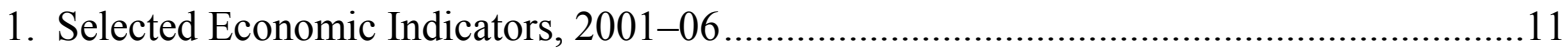

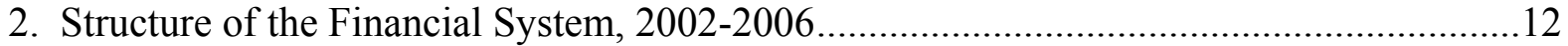

3. Financial Soundness Indicators for the Banking Sector, 2002-2006 ...........................16

4. Financial Ratios for the Nonfinancial Corporate and Household Sectors, 2001-2006 ......20

5. Stress Test Results ................................................................................................22

Figures

1. Composition of Commercial Credit and Consumer Finance .........................................13

2. Financial Soundness Indicators for Selected Emerging Countries, 2005 .......................17

3. Estimated Bank Expected Default Frequencies ............................................................18

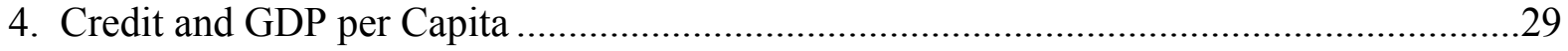

Boxes

1. Financial Sector Impact of the Market Turbulence of mid-2006 ...................................19

2. Nonfinancial Corporate Sector Vulnerabilities.......................................................21

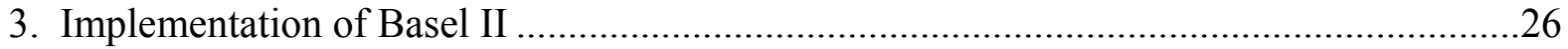


Annex

Observance of Financial Sector Standards and Codes-Summary

Annex Tables

6. Recommended Plan of Actions to Improve Observance of IMF's MFP

Transparency Code Practices-Monetary Policy

7. Recommended Action Plan to Improve Compliance with the BCP.

8. Recommended Plan of Actions to Improve Implementation of

the OSCO Objectives and Principles for Securities Regulation

Appendixes

I. Structure of the Financial System.

II. Stress Testing: Coverage and Results

Appendix Tables

9. Selected Results of the Top-down Market Risk Stress Tests

10. Selected Results of Stress Tests on Market, Interest Rate, and

Exchange Rate Risk

11. Market Risk Impact on Mark-to-Market Portfolio, Banks' Estimates,

December 2005

12. Sensitivity Analysis Estimates of Credit Risk, December 2005

13. Impact of Scenarios on Banking Sector Capital, 2005-2008 


\section{GLOSSARY}

\begin{tabular}{|c|c|}
\hline ABS & Asset-Backed Securities \\
\hline AML & Anti-Money Laundering \\
\hline $\mathrm{BCP}$ & Basel Core Principles for Effective Banking Supervision \\
\hline BL & Banking Law \\
\hline BRSA & Banking Regulation and Supervision Agency \\
\hline BITT & Bank and Insurance Transactions Tax \\
\hline BKM & Bank Card Center \\
\hline CAR & Capital Adequacy Ratio \\
\hline CAST & Computer-Assisted Supervision Tools \\
\hline CBRT & Central Bank of the Republic of Turkey \\
\hline CDD & Customer Due Diligence \\
\hline CFT & Combating the Financing of Terrorism \\
\hline CIS & Collective Investment Scheme \\
\hline $\mathrm{CMB}$ & Capital Markets Board \\
\hline $\mathrm{CP}$ & Core Principle of the $\mathrm{BCP}$ \\
\hline CPSIPS & Core Principles for Systemically Important Payment Systems \\
\hline CPSS & Committee on Payment and Settlement Systems \\
\hline CRA & Central Registry Agency \\
\hline DvP & Delivery versus Payment \\
\hline EBLI & Emerging Local Markets Index \\
\hline EDF & Expected Default Frequency \\
\hline EMBI & Emerging Market Bond Index \\
\hline EU & European Union \\
\hline FDI & Foreign Direct Investment \\
\hline FATF & Financial Action Task Force \\
\hline FSC & Financial Sector Commission \\
\hline FSIs & Financial Soundness Indicators \\
\hline FSAP & Financial Sector Assessment Program \\
\hline FSSA & Financial Sector Stability Assessment \\
\hline GDP & Gross Domestic Product \\
\hline GNP & Gross National Product \\
\hline IAS & International Accounting Standards \\
\hline $\mathrm{ICH}$ & Interbank Clearing House \\
\hline IFRS & International Financial Reporting Standards \\
\hline IMF & International Monetary Fund \\
\hline IOSCO & International Organization of Securities Commissions \\
\hline IPO & Initial Public Offering \\
\hline ISE & Istanbul Stock Exchange \\
\hline KKB & Credit Bureau of Turkey \\
\hline LGD & Losses-given-default \\
\hline MASAK & Financial Crime Investigation Board \\
\hline
\end{tabular}




$\begin{array}{ll}\text { MOU } & \text { Memorandum of Understanding } \\ \text { NBFIs } & \text { Nonbank Financial Institutions } \\ \text { NPL } & \text { Nonperforming Loan } \\ \text { OECD } & \text { Organization of Economic Cooperation and Development } \\ \text { OTC } & \text { Over-the-Counter } \\ \text { PD } & \text { Probability of Default } \\ \text { ROA } & \text { Return on Assets } \\ \text { ROE } & \text { Return on Equity } \\ \text { ROSC } & \text { Report on Observance of Standards and Codes } \\ \text { RTGS } & \text { Real Time Gross Settlement System } \\ \text { RUSF } & \text { Resource Utilization Support Fund } \\ \text { SDIF } & \text { Savings Deposit Insurance Fund } \\ \text { SMEs } & \text { Small and Medium-sized Enterprises } \\ \text { SPO } & \text { State Planning Organization } \\ \text { SRO } & \text { Self-Regulating Organization } \\ \text { TIC } & \text { Turkish Interbank Clearing } \\ \text { TOKI } & \text { Housing Development Administration of Turkey } \\ \text { VaR } & \text { Value-at-Risk } \\ \text { YTL } & \text { New Turkish Lira }\end{array}$




\section{EXECUTIVE SUMMARY}

Turkey's financial system has strengthened markedly over the last five years. It is likely to continue to develop rapidly and become more integrated internationally, but this process must be carefully managed to preserve soundness.

\section{Risk factors and vulnerabilities}

The financial system does not appear to face major immediate threats, but vulnerabilities remain. This conclusion is supported by the extensive stress testing exercise. A number of institutions could be significantly affected by shocks related to the following factors:

- Macroeconomic volatility, especially because of the large current account deficit. Turkey remains dependent on capital inflows and thus on international investor sentiment. Moreover, continued efforts are still needed to anchor inflation at low levels, and the stock of government debt remains relatively high, albeit declining.

- The legacy of macroeconomic and financial market instability. While the credibility of economic management has been strengthened over the past five years, savers and investors' confidence may still be fragile.

- Risks from rapid credit expansion into new activities-including housing lending and credit cards_-involving new borrowers. Although credit growth has slowed since June 2006, it remains rapid. Competitive pressures (e.g., for housing loans, which may increase following passage of the Mortgage Law) may lower underwriting standards.

- Banks bearing large interest rate risk. The risk arises mainly because of duration mismatch between government securities and housing loans on the one hand and customer deposits on the other.

- Sovereign risk. Large holdings of public sector debt by banks makes their solvency, profitability, and liquidity highly sensitive to adverse market revaluation of these securities in the event of external shocks or/and internal political uncertainties.

- Lending in foreign currency, which still accounts for almost one third of bank loans, exposing banks to foreign currency risk indirectly via credit risk. It appears that restrictions on foreign currency lending to non-exporters are sometimes circumvented, for example, by granting foreign currency loans offshore or indexing loans to foreign currency. 


\section{Regulation, supervision, and enforcement}

Effective regulation, supervision, and supporting infrastructure are needed to reduce the systemic impact of any shock that may impinge upon the financial system. Progress has been made, and the authorities recognize that more efforts are needed.

\section{Regulation and supervision by the Banking Regulation and Supervision Agency (BRSA) and the other relevant agencies is much improved. The immediate challenges are to implement fully the new Banking Law (BL) and accompanying regulations, and to ensure that all deviations from regulatory requirements are corrected promptly. Building on the increased legal protection afforded by the new BL, the authorities need to reinforce their reputation for taking decisive action, and should move toward a system of trigger points for supervisory action. Over time, supervision has to keep up with the rapid advances in banking practice, such as in risk modeling, and to cover new forms of business, such as that of mortgage companies, which are likely to expand rapidly following passage of the mortgage law. The growing international connections of banks operating in Turkey (notably through foreign direct investment, FDI) may bring further improvements in risk management and product development, but also increase the need for domestic supervisors to cooperate intensively with counterparts abroad. In this connection, the levying of transaction taxes not only raises the cost of investment financing and discourages saving, but also favors the use of offshore and overseas banks, which can facilitate the circumvention of prudential requirements.}

Improvements have been made in enhancing procedures for dealing with periods of strain in the banking system and the eventual exit of failing banks, but further enhancements are needed. The Central Bank of the Republic of Turkey (CBRT) has effective instruments for managing liquidity, and flexibility to provide emergency lending assistance. The Savings Deposit Insurance Fund (SDIF) has powers to resolve problem banks, but procedures for transferring a failing bank to the SDIF may be prone to delay. Furthermore, the framework under which the SDIF may resolve such banks may generate fiscal costs, for example, by creating a de facto guarantee on all deposits of a transferred bank.

Capital market regulation and supervision is broadly satisfactory. The Capital Markets Board (CMB) is implementing an action plan to achieve convergence to European practices, and a new Capital Markets Law is scheduled to be presented in 2008. Payment and security settlement systems are modern, and generally well-regulated and supervised.

\section{Broadening the financial sector}

The non-bank financial sector is beginning to grow rapidly. Major steps for the non-bank sector include the new framework for mortgage securitization, and the presentation of the Insurance Law to parliament. The prospective Insurance Law will also be helpful in fostering the development of institutional savings schemes. The Istanbul Stock Exchange (ISE) 
functions well, but issues relating to its eventual privatization should not be allowed to delay on-going modernization and the maintenance of its international competitiveness. The authorities have been extending the maturities of public sector debt and increasing the share of local-currency financing as part of a comprehensive debt management strategy.

Transparency and corporate governance still need improvement. Although progress has been made in a number of regards, balance sheets of non-listed companies are not fully transparent; corporate ownership is often difficult to track; and major shareholders enjoy some (limited) privileges in terms of market conduct and lending.

\section{Policy recommendations}

Policies to maintain macroeconomic stability, such as a commitment to a declining path of inflation and fiscal consolidation, are preconditions for sound financial sector development. The authorities will need to remain unwavering in their commitment to sound policies to reinforce confidence and create room for the new financial markets to flourish.

The specific policy recommendations made as part of the FSAP are designed to reduce financial sector vulnerabilities while promoting financial sector development and thus overall growth. The two objectives are complementary. Many of the recommendations relate to the strengthening of preventative, prudential measures, and to improvements in mechanisms to deal efficiently with difficulties that may arise, for example, in the resolution of problem banks. Others, such as on bank privatization, development of the nonbank sector, access to finance, and corporate governance, should contribute to economic efficiency and the diversification of the financial system.

The authorities have already taken measures in a number of areas in line with recommendations during the FSAP, including raising required general provisions, strengthening the minimum capital adequacy ratio (CAR), issuing inflation indexed debt, and taking forward the Mortgage and Insurance Laws.

The following table summarizes the main recommendations. "Short term" actions are those that can and should be undertaken within the next six to twelve months. "Medium term" actions are those that are less time-critical or require a longer lead time, in which case preparations should begin in the short term. 


\section{MAIN RECOMMENDATIONS}

\begin{tabular}{|c|c|c|}
\hline Sector & Priority & Recommendation \\
\hline \multicolumn{3}{|l|}{ Short-term } \\
\hline All & High & $\begin{array}{l}\text { Complete and implement the regulations associated with the new } \\
\text { Mortgage Law and pass the Insurance Law. In particular, establish } \\
\text { prudential norms for mortgage lending, and assign related oversight } \\
\text { responsibilities. }\end{array}$ \\
\hline Banking & High & $\begin{array}{l}\text { Implement all regulations for the new BL. Develop, and implement, a } \\
\text { comprehensive plan for the BRSA to supervise banks in line with the } \\
\text { new legal and regulatory framework, including their risk management. }\end{array}$ \\
\hline Banking & High & $\begin{array}{l}\text { Review and amend procedures for handling failing banks, and ensure } \\
\text { active involvement of all relevant agencies, to ensure timely and cost- } \\
\text { effective action. }\end{array}$ \\
\hline Banking & Medium & $\begin{array}{l}\text { Ensure that foreign-currency linked domestic currency loans are subject } \\
\text { to similar constraints as foreign currency loans. }\end{array}$ \\
\hline $\begin{array}{l}\text { Corporate } \\
\text { governance }\end{array}$ & High & $\begin{array}{l}\text { Review major corporate shareholders' regulatory treatment to remove } \\
\text { residual privileges. }\end{array}$ \\
\hline \multicolumn{3}{|l|}{ Medium-term } \\
\hline All & High & Phase out transaction taxes. \\
\hline Banking & High & Complete privatization of public banks. \\
\hline Banking & Medium & Refine data collection and analysis \\
\hline Banking & High & $\begin{array}{l}\text { Conclude Memoranda of Understanding (MoUs) with remaining } \\
\text { significant foreign supervision counterparties. }\end{array}$ \\
\hline Banking & Medium & $\begin{array}{l}\text { Review mechanisms to ensure financial independence of supervisory } \\
\text { agencies. }\end{array}$ \\
\hline Insurance & High & $\begin{array}{l}\text { Establish mechanisms to generate more reliable data on insurance } \\
\text { companies' provisions and capital. }\end{array}$ \\
\hline Capital mkts. & High & Resolve problems regarding privatization of the ISE. \\
\hline Capital mkts. & High & Adopt the Capital Markets Law in 2008. \\
\hline $\begin{array}{l}\text { Access to } \\
\text { finance }\end{array}$ & Medium & Reduce the costs of creating and realizing collateral. \\
\hline $\begin{array}{l}\text { Corporate } \\
\text { governance }\end{array}$ & High & $\begin{array}{l}\text { Strengthen minority shareholders' protection and raise board members' } \\
\text { accountability. }\end{array}$ \\
\hline $\begin{array}{l}\text { Corporate } \\
\text { governance }\end{array}$ & High & $\begin{array}{l}\text { Further strengthen accounting and auditing, especially in smaller } \\
\text { nonfinancial firms. }\end{array}$ \\
\hline
\end{tabular}




\section{BACKGROUND}

\section{A. Macroeconomic Developments and Vulnerabilities}

1. The Turkish economy and the financial sector have largely recovered from the 2001 crisis (Table 1). That crisis had a deep impact, particularly on the financial system. Several private banks were intervened and resolved, and the state-owned banks were recapitalized. Since then, performance has improved under the authorities' program supported by the Fund and the Bank, and in the context of a benign international financial environment and Turkey's access process with the European Union (EU).

2. Yet, important vulnerabilities remain. Public and private balance sheets are exposed to exchange rate, interest rate, and roll-over risks. High capital inflows have underpinned a trend appreciation of the lira, and, with high oil prices and strong growth, widened the current account deficit. With strongly rising domestic investment and lower domestic saving, notwithstanding the sharply improved fiscal position, growth has become reliant on the availability of foreign savings. Therefore, Turkey remains exposed to fluctuations in market sentiment, as highlighted during the turbulence in May-June 2006.

\section{B. Trends in the Financial System}

3. Banks dominate the financial system (Table 2 and Appendix I). They hold most assets and control the larger nonbank institutions. Three major commercial banks are still effectively in the public sector, but face competition from private banks in most product areas. A prominent recent trend is the entry of foreign investors, mainly from Europe, into a number of banks and insurance companies. ${ }^{1}$

4. With the return of confidence and greater economic predictability, deposits and loans, especially consumer credit and housing loans, have expanded rapidly (Figure 1 ). ${ }^{2}$ Banks have sought to exploit economies of scale and achieve market share in the new areas of activity. Government securities still account for about a third of banks' total assets, and are especially important in the recapitalized state-owned banks, though remaining nonmarketable securities paying premium interest rates are set to mature. Thus, the system is in transition from one dominated by the financing of government and a few major enterprises to one engaged in extensive private sector intermediation.

\footnotetext{
${ }^{1}$ At end-2006, about 25 percent of the Turkish banking system was effectively under foreign control. In most Central and Eastern European countries, at least three quarters of the banking system is under foreign ownership.

${ }^{2}$ The trend increase in intermediation began in the mid-1990s but was interrupted by the 2001 crisis.
} 
Table 1. Selected Economic Indicators, 2001-06

(In percent except where indicated)

\begin{tabular}{|c|c|c|c|c|c|c|c|}
\hline & 2001 & 2002 & 2003 & 2004 & 2005 & 2006 & 2007 Proj. \\
\hline GNP (US\$ billions) & 144.0 & 182.7 & 238.5 & 301.5 & 361.9 & 401.4 & $\ldots$ \\
\hline GNP per capital (in US\$) & 2,140 & 2,671 & 3,431 & 4,271 & 5,054 & 5,534 & 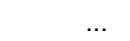 \\
\hline Population (in millions) & 67.3 & 68.4 & 69.5 & 70.6 & 71.6 & 72.6 & 73.6 \\
\hline GNP (Turkish lira billions) & 176.5 & 275.0 & 356.7 & 428.9 & 486.4 & 575.8 & 646.9 \\
\hline Nominal GNP growth rate & 40.5 & 55.8 & 29.7 & 20.3 & 13.4 & 18.4 & 12.4 \\
\hline Real GNP growth rate & -9.5 & 7.9 & 5.9 & 9.9 & 7.6 & 6.0 & 5.0 \\
\hline CPI (12-month, end-of period) & 68.5 & 29.7 & 18.4 & 9.4 & 7.7 & 9.7 & 6.0 \\
\hline Savings/GDP & 19.3 & 20.7 & 19.6 & 20.6 & 18.5 & 15.6 & 16.1 \\
\hline Investment/GDP & 16.9 & 21.5 & 23.0 & 25.8 & 24.8 & 23.5 & 23.4 \\
\hline Public sector primary balance/GDP & 5.5 & 5.1 & 6.2 & 7.2 & 6.8 & 6.6 & 6.7 \\
\hline Public sector overall balance/GDP & -17.1 & -12.5 & -9.1 & -4.6 & -1.2 & -0.8 & -0.9 \\
\hline Public sector net debt/GDP & 90.4 & 78.4 & 70.3 & 64.0 & 55.3 & 44.8 & 40.9 \\
\hline of which: domestic & 52.9 & 46.3 & 48.4 & 46.5 & 46.8 & 37.5 & 33.8 \\
\hline Nominal growth of M2Y broad money & 87.5 & 25.4 & 13.0 & 22.1 & 24.5 & 24.1 & 14.9 \\
\hline Real broad money growth $1 /$ & 11.2 & -3.3 & -4.6 & 11.7 & 15.3 & 13.5 & 8.9 \\
\hline Real credit to the private sector growth $1 /$ & -27.5 & -16.5 & 20.1 & 28.5 & 33.6 & 25.1 & $\ldots$ \\
\hline Base money/GDP & 4.4 & 3.8 & 4.2 & 4.7 & 6.7 & 7.3 & 6.3 \\
\hline Broad money/GDP & 60.4 & 48.6 & 42.3 & 43.0 & 47.2 & 50.7 & 51.9 \\
\hline Lira broad money/GDP & 26.8 & 22.5 & 23.2 & 25.3 & 31.5 & 32.9 & 33.5 \\
\hline Private credit/GDP & 21.9 & 15.3 & 16.7 & 21.0 & 26.7 & 31.7 & $\ldots$ \\
\hline Average nominal treasury bill interest rate & 93.6 & 64.6 & 45.1 & 24.7 & 16.2 & 18.1 & $\ldots$ \\
\hline Average nominal deposit rate (eop) & 54.3 & 39.3 & 23.5 & 17.3 & 13.7 & $\ldots$ & $\ldots$ \\
\hline Average nominal lending rate (eop) & 74.3 & 56.0 & 42.7 & 34.8 & 23.5 & $\ldots$ & $\ldots$ \\
\hline External current account balance/GDP & 2.4 & -0.8 & -3.4 & -5.2 & -6.3 & -7.9 & -7.3 \\
\hline Net foreign direct investment/GDP & 1.9 & 0.5 & 0.5 & 0.7 & 2.4 & 4.8 & 3.5 \\
\hline Gross external debt/GDP & 93.1 & 77.3 & 56.4 & 50.1 & 46.7 & 50.5 & 52.8 \\
\hline Gross official reserves (US\$ billions) & 19.8 & 28.1 & 35.2 & 37.6 & 52.2 & 63.3 & 68.6 \\
\hline REER appreciation (CPI based, period average) & -17.6 & 11.4 & 8.9 & 5.1 & 11.5 & 0.4 & $\ldots$ \\
\hline Exchange rate (YTL/US\$, eop) & 1.45 & 1.64 & 1.40 & 1.34 & 1.35 & 1.41 & $\ldots$ \\
\hline
\end{tabular}

Sources: Data provided by the Turkish authorities; and IMF staff estimates and projections.

1/ Deflated by the CPI. 


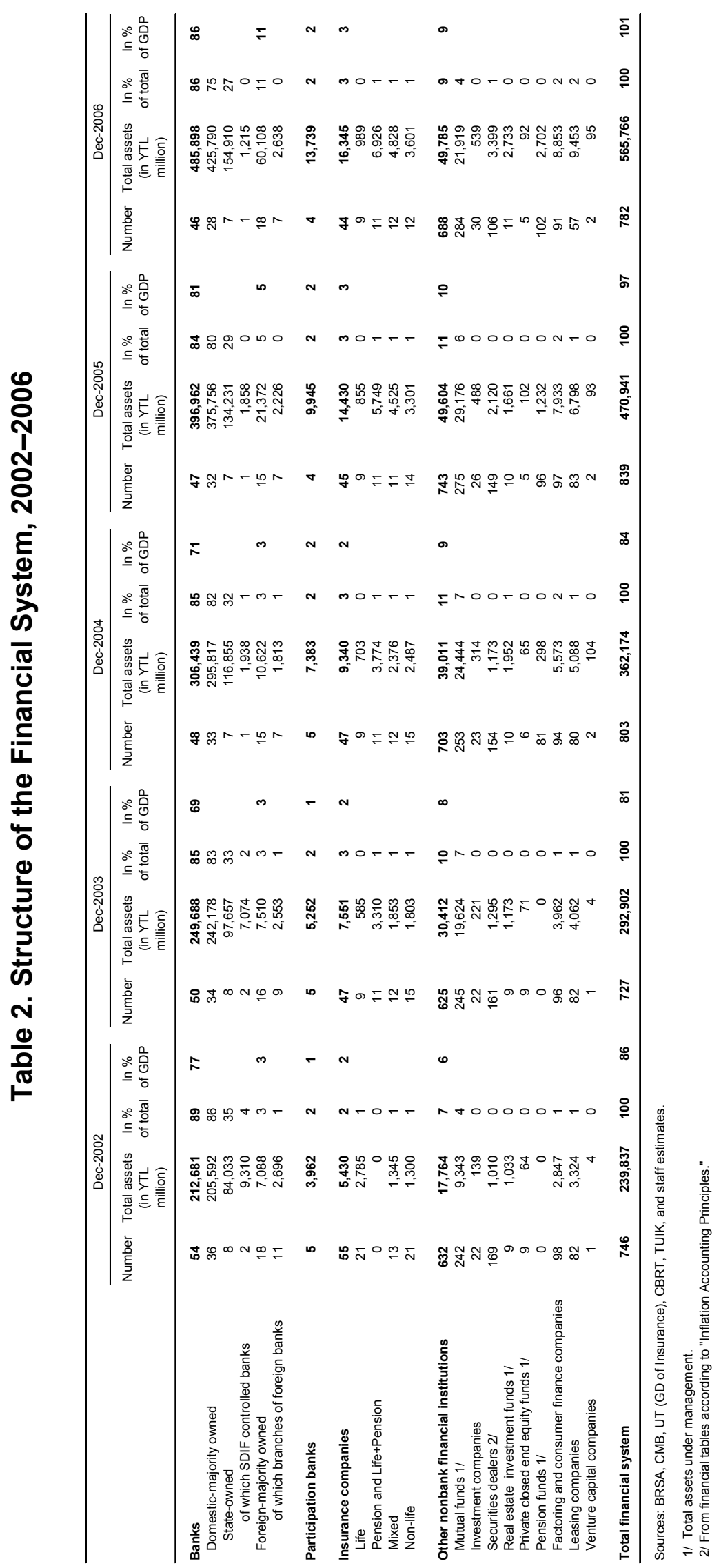


Figure 1. Composition of Commercial Credit and Consumer Finance (Percentage share of GDP)

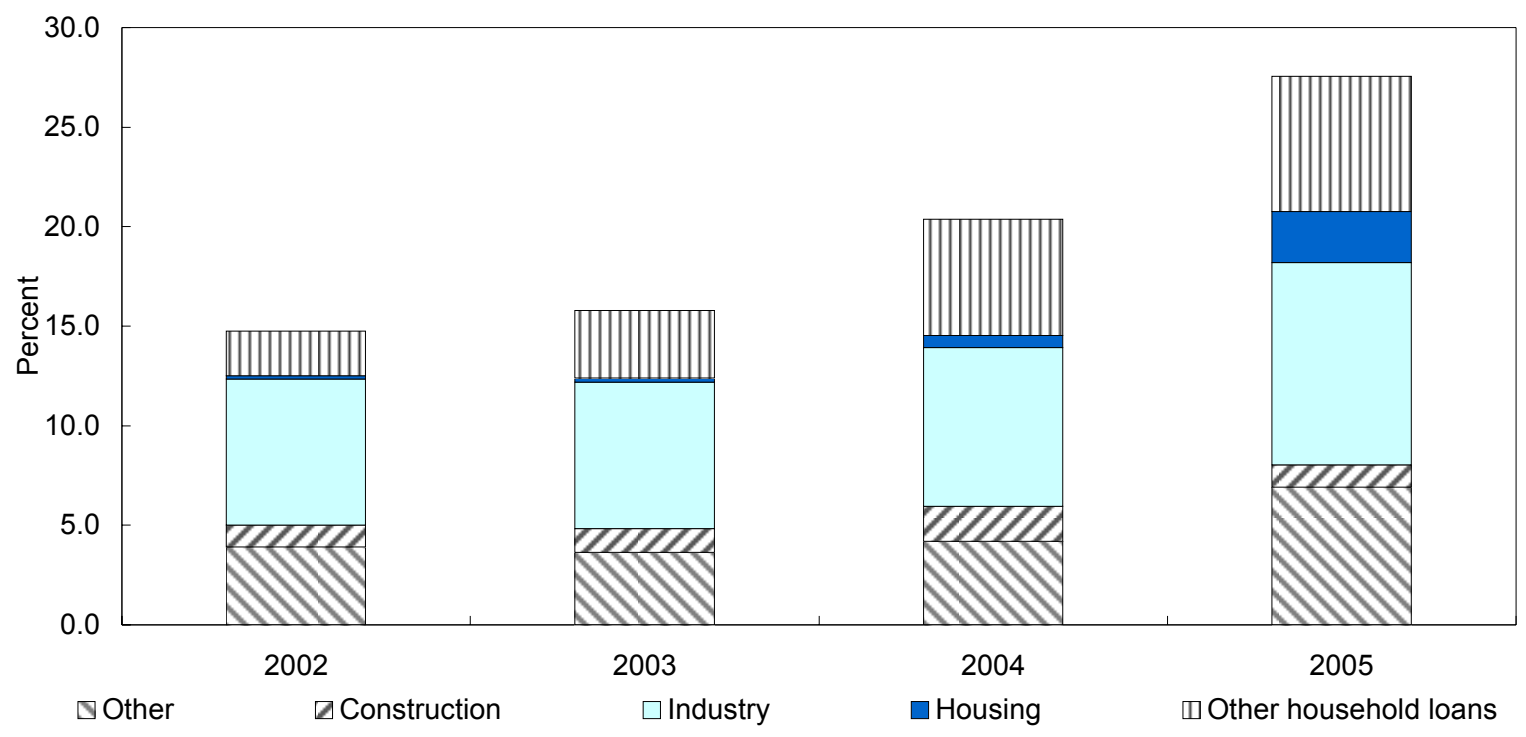

Source: Turkish authorities, and staff estimates.

\section{Nonetheless, deposit maturities are short, dollarization persistent, and}

transaction taxes have discouraged domestic intermediation. ${ }^{3}$ Average deposit maturity is below three months, yet loan maturity is rising, increasing to maturity mis-matches. Banks have resorted to obtaining longer-term syndicated or securitized loans from abroad, which are hedged through swap operations, to finance longer-term corporate and housing loans. ${ }^{4}$ Dollarization of deposits has been declining in relative, but not absolute, terms, although there has been some rise after the May-June 2006 turbulence. About one third of loans are in foreign currency or foreign exchange indexed. Banks have relied on foreign inflows, often hedged with off-balance sheet derivatives, to finance a significant part of the credit expansion. The interbank New Turkish Lira (YTL) market is only moderately active, and repurchase operations (repos) are limited. In part this reflects the attractiveness of central bank deposit facilities, transaction costs, and legal and contractual concerns. Abolition of financial transaction taxes would lower intermediation spreads and deepen Turkish financial markets. While the authorities agree on the desirability of eliminating these taxes, they aim to do so gradually as fiscal space is created.

6. The outstanding stock of government debt is large, but public debt management has improved. The Treasury has been actively extending the duration and maturity of its debt, and decreasing reliance on foreign currency denominated debt, although a large portion

3 These include the Banking Transaction and Insurance Tax (BITT), which generates revenue of 0.5 percent of GDP, and the Resource Utilization and Support Fund (RUSF), which generates revenue of 0.3 percent of GDP.

${ }^{4}$ The swap operations are reportedly conducted with reputable counterparties. 
still carries a floating rate. The first inflation-indexed debt after several years was issued in February 2007.

7. Stock market capitalization has risen sharply, but the development of the equity and corporate bond markets is limited. Initial public offerings and sales of additional equity in listed companies are resuming on the ISE; the first domestic local currency corporate bond for a decade was issued in August 2006.

8. Nonbank financial institutions (NBFIs) are also growing rapidly, but remain small. The insurance sector is reviving after having been badly affected in the past by chronic high inflation, and should be boosted by the proposed Insurance Law. The introduction of individual pension saving plans in October 2003 also represented an important positive development. The ongoing reform of corporate pensions included in the proposed Insurance Law is expected to expand the scope of private pensions further.

\section{Resilience ANd Potential Vulnerabilities}

9. Banks' improved financial situation and risk management techniques, supported by a better framework of regulation, supervision, and intervention, have made the system more resilient. Enabling macroeconomic circumstances include the reduction of inflation, a flexible exchange rate regime, and improved fiscal performance.

10. However, vulnerabilities persist, and new vulnerabilities may be emerging as banks expand rapidly into new markets, such as household lending. Moreover, Turkey's history of macroeconomic and financial sector instability still affects savers' and investors' confidence, and traditional structural features such as connections within conglomerates may continue to contribute to vulnerabilities. ${ }^{5}$

11. The internationalization of banking activity, while generally beneficial, may create transitional risks and complicate financial sector policy. On the one hand, Turkish banks already conduct a high volume of business in offshore centers or elsewhere overseas, partly encouraged by banking transaction taxes. Since consolidated supervision is in place, the BRSA should ensure that the banks fully take into account total risks facing borrowers, including those generated by lending in foreign currency through offshore subsidiaries or branches. On the other hand, Turkish banks with foreign partners may be able to import better risk management techniques, and have access to cheaper financing and capital. However, these factors may also accelerate aggregate credit expansion and risk taking, and facilitate the circumvention of prudential measures.

\footnotetext{
${ }^{5}$ However, the relative importance of conglomerates is probably declining as access to financial services has broadened.
} 


\section{A. Trends in Financial Soundness Indicators}

12. Financial soundness indicators (FSIs) have broadly improved in parallel with the macroeconomic indicators (Table 3). Banks have rebuilt capital and provisions, and NPL rates have fallen steadily even allowing for the effect of rapid credit growth, although NPL ratios for credit card debt have been rising recently. ${ }^{6}$ Post-crisis profitability rebounded as banks benefited from wide interest rate spreads, valuation gains, and improvements in loan quality. FSIs are broadly similar across the major banks, but the aggregates mask the position of smaller banks, some of which have relatively low and variable profits. FSIs in Turkey are comparable to those found in other emerging market economies, with somewhat aboveaverage capitalization and somewhat lower return on equity (Figure 2). Efficiency measures, such as cost ratios, are satisfactory in international comparison.

13. Return on equity has been moderate, despite strong growth, largely because banks have been competing intensely for market share - a trend that is likely to continue. ${ }^{7}$ Specifically, competition had driven interest rates on some loans to households, especially on housing loans, down to roughly the cost of funding, and led to increases in the loan maturity and the percentage of value they cover. This trend was halted by the May/June 2006 turbulence. However, the recently-passed Mortgage Law will allow banks to grant mortgages under more flexible conditions, and to mitigate their risks through securitization. Experience from other countries suggests credit growth could therefore reaccelerate, raising new supervisory challenges.

\section{Banks have maintained adequate liquidity buffers, and tightly limit their open} foreign currency positions. In particular, there is no evidence of the use of related or fictitious counterparties in hedging transactions, which were widespread at the time of the 2001 crisis. However, bank balance sheets exhibit a significant duration mismatch, with deposit duration lengthening more slowly than credit duration.

15. Market indicators corroborate balance sheet indicators. Estimated expected default frequencies (EDFs) based on equity prices for 15 quoted banks show a trend decline (Figure 3).

\footnotetext{
${ }^{6}$ The decline in NPL rates is attributable not only to the improved economy but also to the statistical effect of fast credit growth and to loan rescheduling under the "Istanbul approach" following the crisis. The grace periods under the rescheduling are coming to an end, but some banks have already made provisions against these loans, and "Istanbul approach" loans now represent only a small fraction of banks' portfolios.

${ }^{7}$ Profitability measures are complicated by several idiosyncratic events at individual banks and changes in accounting practices, such as with regard to allowances for inflation.
} 
Table 3. Financial Soundness Indicators for the Banking Sector, 2002-2006 ${ }^{1 /}$ (In percent, unless otherwise indicated; end of period)

\begin{tabular}{|c|c|c|c|c|c|c|}
\hline & 2002 & 2003 & 2004 & 2005 & & \\
\hline & & & & & Jun. & Dec. \\
\hline \multicolumn{7}{|l|}{ Capital Adequacy } \\
\hline Regulatory capital/risk-weighted assets & 24.4 & 29.5 & 27.4 & 22.8 & 17.2 & 21.1 \\
\hline Regulatory Tier I capital/risk-weighted assets & 24.7 & 30.1 & 26.9 & 23.2 & 19.1 & 20.3 \\
\hline Capital/assets & 11.5 & 13.7 & 14.4 & 12.9 & 10.5 & 11.3 \\
\hline \multicolumn{7}{|l|}{ Asset Composition and Quality } \\
\hline \multicolumn{7}{|l|}{ Sectoral distribution of loans/total loans } \\
\hline Agriculture & 6.7 & 4.1 & 4.9 & 4.2 & 3.7 & 3.0 \\
\hline Mining & 1.3 & 1.4 & 1.3 & 1.3 & 3.0 & 1.7 \\
\hline Production/manufacturing & 27.4 & 37.4 & 24.6 & 22.9 & 26.5 & 25.0 \\
\hline Construction & 8.9 & 5.2 & 3.3 & 3.4 & 6.0 & 7.9 \\
\hline Finance 2/ & 32.2 & 26.5 & 17.2 & 20.0 & 16.8 & 15.3 \\
\hline Retail & 0.4 & 1.2 & 26.4 & 27.6 & 26.5 & 27.0 \\
\hline Other & 23.0 & 24.2 & 22.4 & 20.7 & 17.6 & 20.1 \\
\hline Non-performing loans/total loans & 12.7 & 8.9 & 4.9 & 3.9 & 3.3 & 3.2 \\
\hline Specific provisions/gross non performing loans & 64.2 & 88.5 & 88.1 & 89.8 & 90.8 & 90.8 \\
\hline Non performing loans net of provisions/Tier I capital & 16.3 & 3.1 & 1.9 & 1.7 & 1.5 & 1.4 \\
\hline Loans/shareholders and parent companies/total loans & 11.5 & 5.9 & 4.1 & 1.3 & 1.1 & 0.8 \\
\hline Large exposures/Tier I capital & 31.4 & 10.9 & 7.9 & 18.0 & 19.4 & $\ldots$ \\
\hline Specific provisions/gross loans & 11.3 & 10.2 & 5.3 & 4.3 & 3.0 & 2.9 \\
\hline General provisions/gross loans & 3.2 & 2.3 & 2.2 & 2.0 & 1.7 & 1.7 \\
\hline \multicolumn{7}{|l|}{ Profitability } \\
\hline Return on Average Assets (ROAA) $3 /$ & 1.2 & 2.4 & 2.3 & 1.6 & 1.2 & 2.3 \\
\hline Return on Average Equity (ROAE) $3 /$ & 10.6 & 18.8 & 16.7 & 11.9 & 10.1 & 21.5 \\
\hline Net interest margin/gross income & 59.9 & 43.8 & 62.5 & 60.2 & 58.5 & 59.3 \\
\hline Non-interest income/gross income & 40.1 & 56.2 & 37.5 & 39.8 & 41.5 & 40.7 \\
\hline Trading and foreign exchange income/gross income & 4.3 & 27.3 & 8.3 & 7.1 & 11.3 & 3.6 \\
\hline Non-interest expenses/gross income & 61.6 & 54.0 & 53.9 & 49.3 & 43.8 & 45.9 \\
\hline Non-interest expenses/average assets & 6.1 & 5.4 & 4.9 & 3.8 & 3.4 & 3.4 \\
\hline Personnel expenses/non-interest expenses & 28.8 & 31.3 & 31.6 & 36.3 & 42.1 & 40.4 \\
\hline \multicolumn{7}{|l|}{ Liquidity } \\
\hline Core liquid assets/total assets & 10.7 & 9.9 & 9.4 & 11.4 & 12.8 & 14.9 \\
\hline Core liquid assets/short-term liabilities & 16.8 & 16.5 & 15.6 & 18.4 & 18.3 & 21.4 \\
\hline Liquid assets/total assets & 51.6 & 53.1 & 50.2 & 47.8 & 48.3 & 48.0 \\
\hline Liquid assets/short term liabilities & 81.4 & 88.8 & 83.4 & 77.1 & 68.8 & 68.8 \\
\hline Foreign currency loans/total loans 3/ & 50.7 & 41.5 & 34.2 & 27.9 & 30.5 & 26.1 \\
\hline Foreign currency deposits/total deposits & 57.3 & 48.6 & 44.7 & 36.4 & 36.9 & 38.8 \\
\hline Foreign currency liabilities/total liabilities & 57.6 & 50.6 & 47.4 & 41.4 & 44.2 & 42.8 \\
\hline Deposits/assets 3/ & 65.6 & 62.8 & 63.0 & 61.9 & 62.5 & 61.8 \\
\hline Loans/deposits $3 /$ & 42.3 & 47.2 & 54.3 & 63.7 & 71.0 & 72.2 \\
\hline Foreign currency loans/Foreign currency deposits 3/ & 37.4 & 40.4 & 41.5 & 48.7 & 58.7 & 48.5 \\
\hline \multicolumn{7}{|l|}{ Sensitivity/Market Risk } \\
\hline Net open FX position (overall)/Tier I capital & $\ldots$ & 0.8 & -0.2 & -0.3 & -1.2 & 0.7 \\
\hline Off-balance sheet operations/assets & 42.3 & 49.7 & 51.0 & 50.6 & 55.1 & 55.2 \\
\hline Gross asset position in derivatives/Tier I capital & 46.1 & 47.6 & 44.2 & 67.5 & 100.9 & 98.1 \\
\hline Gross liability position in derivatives/Tier I capital & 64.7 & 60.4 & 53.5 & 75.7 & 105.4 & 100.9 \\
\hline
\end{tabular}

Source: BRSA and IMF Staff calculations

1/ FSIs calculated according to guidelines of IMF FSIs Guide, 2004, and based on the consolidated financial statements of the banking sector, with certain inter sectoral transactions eliminated.

2/ Finance loans include loans given to banks, partipation banks, leasing, factoring, finance companies, insurance and pension funds (excluding compulsory social security institutions), financial intermediation companies, real estate investment trusts, securities invstment trusts, and venture capital companies.

3/ Non interbank loans and deposits used for the calculation of these ratios. 
Figure 2. Financial Soundness Indicators for Selected Emerging Countries, 2005

Capital Adequacy Ratio

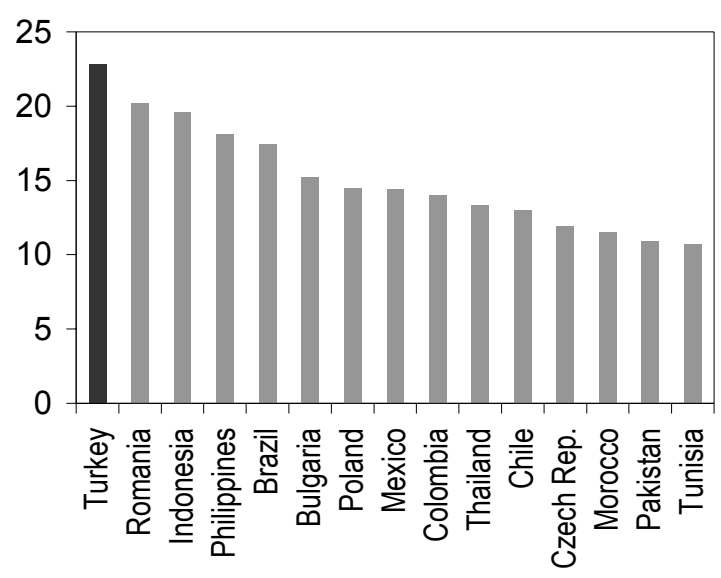

NPLs to total loans
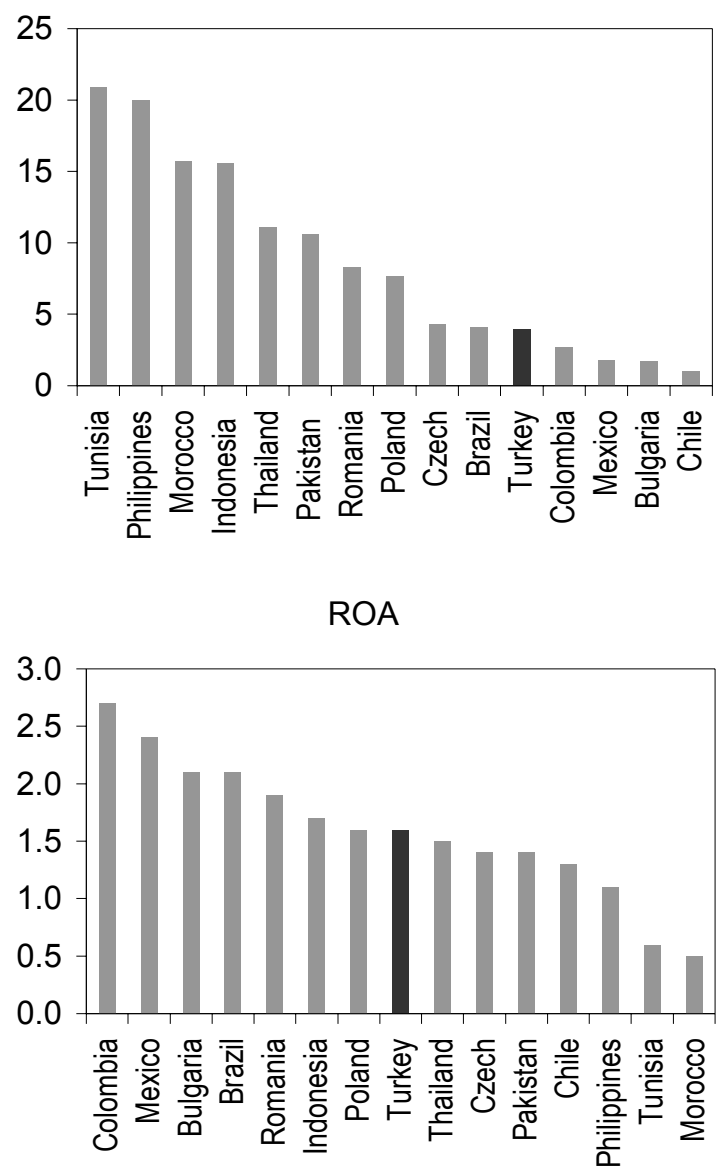

Capital to assets

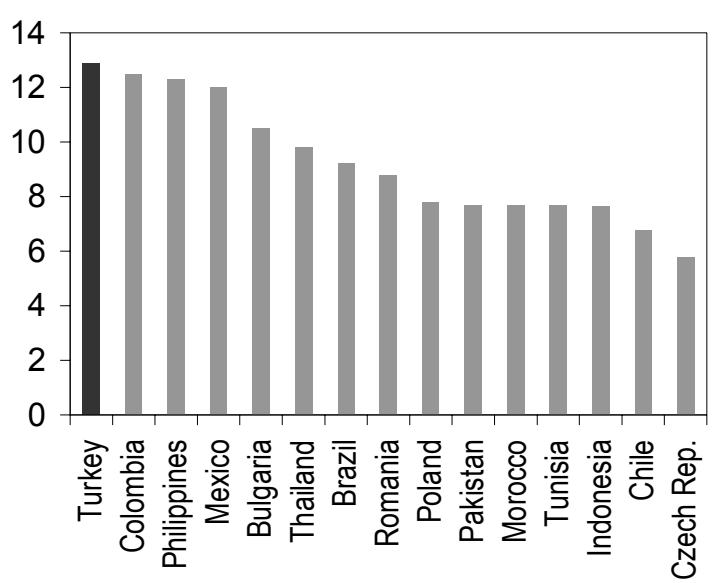

Provisions to NPLs
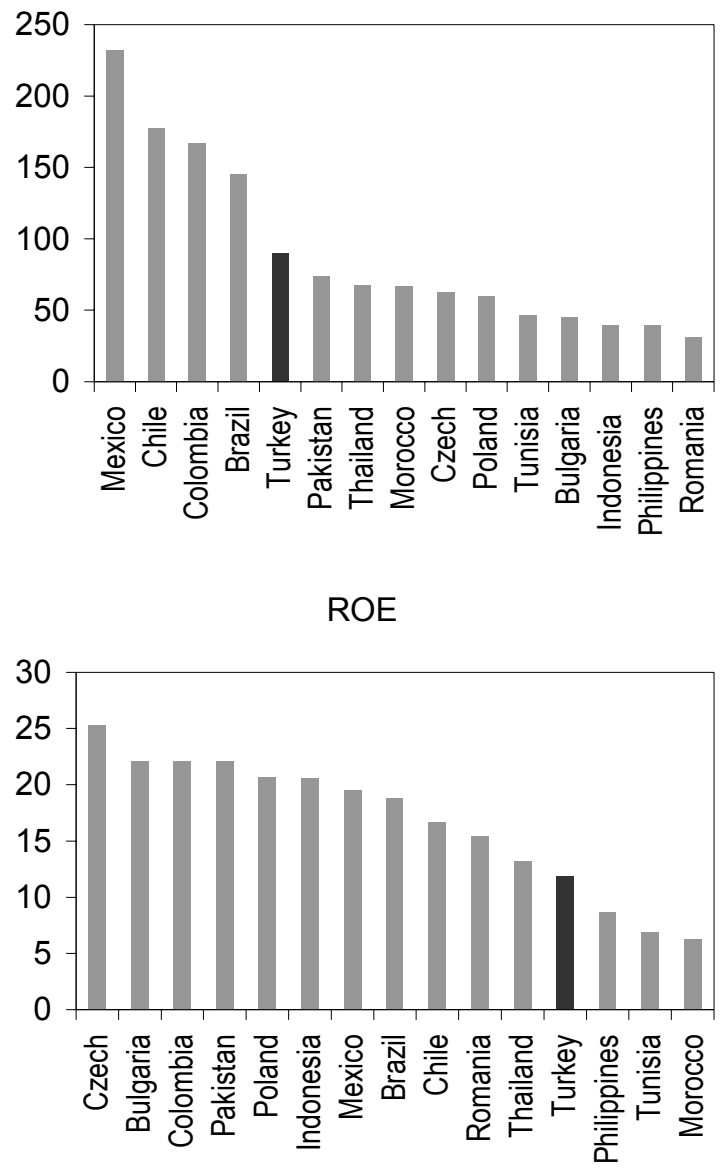
Figure 3. Estimated Bank Expected Default Frequencies

(Percent; by quartile)

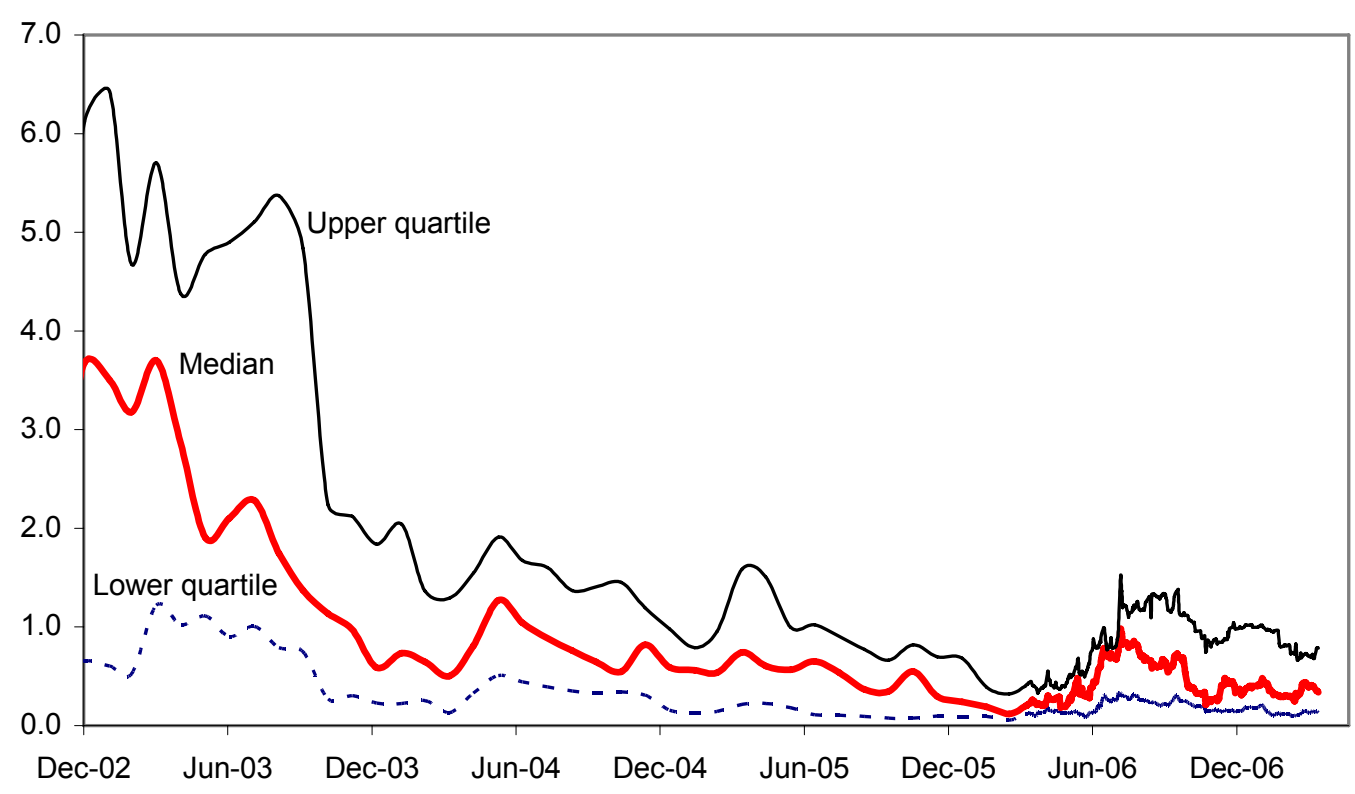

Source: Moody's.

16. Market turbulence in May-June 2006 had a largely temporary effect on banks' capitalization levels, but has slowed credit expansion (Box 1). Renewed world-wide market turbulence in the first quarter of 2007 did not have an especially strong impact on Turkey. This may have been in large part because the increase in perceived risk was concentrated in mature markets, but in addition some of the Turkey-specific factors (such as very rapid credit growth) may have attenuated between June 2006 and early 2007.

17. A specific concern relates to the full recognition of banks' pension liabilities according to International Financial Reporting Standards (IFRS), which may over time affect some banks' profitability. In mid-2005, a large bank recorded very large charges against an unfunded pension deficit. While recognition of these liabilities is welcome, and most banks claim that they fully recognize the present value of the defined benefit obligation, introducing a discount rate consistent with Turkey's inflation targets could lead to a higher valuation of the liabilities.

18. The limited FSIs available for NBFIs are broadly satisfactory. Most insurance companies, for example, seem to be highly capitalized and currently report high profits, although the adequacy and appropriateness of reserving policies are difficult to determine. ${ }^{8}$

\footnotetext{
${ }^{8}$ In most countries, profitable companies tend to overstate reserves and lower reported profits to save taxes, while struggling companies tend to understate reserves to hide their weakness.
} 


\section{Box 1. Financial Sector Impact of the Market Turbulence of Mid-2006}

The market turbulence in May-June 2006 resulted in a sharp depreciation of the YTL and a fall in stock prices, which have subsequently been largely reversed. In response to the turbulence, the CBRT raised interest rates and actively absorbed liquidity from the money markets.

Banks suffered a temporary reduction in capitalization because of mark-to-market valuation losses on their large holdings of government securities; the average CAR declined to 17 percent in mid-year, from over 22 percent at end-2005, with declines in some banks to significantly lower CAR levels. The accounting losses were reversed once the securities began to mature and were rolled over. Stateowned banks were less affected by the turbulence because a large share of their government securities is not tradable and so not marked to market. Given banks' small net foreign currency open positions, direct exchange rate effects were minor.

Banks' capitalization levels rebounded in the second half of 2006, driven mainly by the recovery in market prices; valuation gains on the purchase of government securities sold by others in the aftermath of the turbulence; the sale of fixed assets; and some injections of fresh capital by shareholders. Profitability was helped by declining NPLs and provisioning (however, the aggregates figures are distorted by the large exceptional charges incurred by one bank in 2005).

Lending to households slowed in the second half of 2006: households might have been discouraged from borrowing by higher rates, while the resurgence of dollarization of deposits reduced banks' domestic YTL funding and the cost of their foreign funding hedged by swaps rose sharply. The supply of loans may thus have shifted downwards as banks became more concerned about costs and risks and less concerned about building their client bases.

This episode suggests that banks are more resilient to market turbulence than in the past, and that they and the authorities are in some regards better at managing the attendant risks. Yet, they were also helped by the rapid revival of investor appetite for emerging market assets and the limited spill-over from the shock on to the domestic economy.

19. The corporate sector has been rebuilding its financial strength since 2000 , but foreign exchange exposure remains something of a concern (Table 4 and Box 2). Larger corporations, which publish more financial information, appear to have higher profit margins, greater debt service capacity, and decreased leverage, but maintain significant unhedged foreign currency positions, although they have declined somewhat recently. The corporations have also been able to rebuild financial strength after the turbulence in mid-2006. Available data on the financial burden borne by households suggest that they are not very leveraged, yet the aggregates may mask concentrations in certain segments of society such as urban salary-earners. 


\section{Table 4. Financial Ratios for the Nonfinancial Corporate and Household Sectors, 2001-2006 1/}

\begin{tabular}{|c|c|c|c|c|c|c|c|}
\hline & 2001 & 2002 & 2003 & 2004 & 2005 & 2006Q2 & 2006Q3 \\
\hline \multicolumn{8}{|c|}{ Selected financial ratios for all nonfinancial corporates ${ }^{2}$} \\
\hline Net margin ${ }^{3}$ (in percent) & $\ldots$ & 3.0 & 4.3 & 4.2 & 2.9 & $\ldots$ & $\ldots$ \\
\hline Total liabilities to equity & 2.3 & 1.8 & 1.4 & 1.0 & 1.0 & $\ldots$ & $\ldots$ \\
\hline Total liabilities to assets & 0.7 & 0.6 & 0.6 & 0.5 & 0.5 & $\ldots$ & $\ldots$ \\
\hline Interest coverage ${ }^{4}$ & 1.1 & 1.8 & 3.3 & 3.3 & 3.2 & $\ldots$ & $\ldots$ \\
\hline Current ratio ${ }^{5}$ & 1.1 & 1.3 & 1.3 & 1.4 & 1.4 & $\ldots$ & $\ldots$ \\
\hline Quick ratio ${ }^{6}$ & 0.8 & 0.9 & 0.9 & 1.0 & 1.0 & $\ldots$ & $\ldots$ \\
\hline \multicolumn{8}{|l|}{ Selected financial ratios for large corporations 7} \\
\hline \multicolumn{8}{|l|}{ Profitability indicators ${ }^{8}$} \\
\hline Net margin ${ }^{3}$ & -2.9 & 2.3 & 6.3 & 6.2 & 3.8 & 3.9 & 10.3 \\
\hline Return on assets ${ }^{9}$ & -1.2 & 1.0 & 2.4 & 2.0 & 1.3 & 1.5 & 4.0 \\
\hline Return on equity 10 & -4.5 & 3.1 & 5.8 & 3.8 & 2.3 & 2.9 & 7.5 \\
\hline \multicolumn{8}{|l|}{ Leverage and Debt Structure } \\
\hline Total liabilities to equity & 2.8 & 2.3 & 1.5 & 0.9 & 0.7 & 1.0 & 0.9 \\
\hline Total liabilities to assets & 0.7 & 0.7 & 0.6 & 0.5 & 0.4 & 0.5 & 0.5 \\
\hline Current liabilities to total liabilities & 0.6 & 0.7 & 0.7 & 0.7 & 0.7 & 0.7 & 0.7 \\
\hline Foreign liabilities to total liabilities & $\ldots$ & $\ldots$ & $\ldots$ & 0.5 & 0.6 & 0.6 & 0.5 \\
\hline \multicolumn{8}{|l|}{ Liquidity and Coverage } \\
\hline Interest coverage 4 & 0.4 & 1.6 & 3.1 & 5.8 & 4.4 & 2.8 & 5.9 \\
\hline Current ratio ${ }^{5}$ & 1.0 & 1.0 & 1.1 & 1.3 & 1.3 & 1.2 & 1.3 \\
\hline Quick ratio ${ }^{6}$ & 0.8 & 0.8 & 0.8 & 0.9 & 0.9 & 0.8 & 0.9 \\
\hline Net foreign exchange position to current assets 11 & $\ldots$ & $\ldots$ & $\ldots$ & -0.3 & -0.4 & -0.4 & -0.3 \\
\hline \multicolumn{8}{|l|}{ Household sector financial ratios ${ }^{8}$ (in percent) } \\
\hline Total financial assets/GDP & $\ldots$ & 47.0 & 41.7 & 42.7 & 42.0 & $\ldots$ & $\ldots$ \\
\hline Total finanical liabilities/GDP 12 & $\ldots$ & 2.5 & 3.8 & 6.5 & 10.2 & $\ldots$ & $\ldots$ \\
\hline Household debt/disposable income ${ }^{12}$ & $\ldots$ & 4.8 & 7.5 & 12.8 & $\ldots$ & $\ldots$ & $\ldots$ \\
\hline Interest paid/income ratio ${ }^{12}$ & $\ldots$ & 1.7 & 2.1 & 3.5 & $\ldots$ & $\ldots$ & $\ldots$ \\
\hline
\end{tabular}

Source: BRSA, CBRT, Bloomberg, Istanbul Stock Exchange, and staff estimates.

1/ 2004 figures for nonfinancial corporates are derived from inflation-adjusted financial statements.

2/ Ratios from CBRT Company Accounts database on 7,507 Turkish corporates in 2001, 6,667 in 2002-04, and 7,103 in 2005.

3/ Net profit in percent of net sales.

4/ Operating profits (earnings before interest and taxes) to interest expenses.

$5 /$ Current assets to current liabilities.

6/ Current assets net of inventories to current liabilities.

7/ Ratios computed for 20 companies listed on the ISE, representing 37 percent of market capitalization of nonfinancial firms listed on the ISE. Net sales of these companies represented 13 percent of GDP in 2005.

8/ In percent.

9/ Net profit in percent of total assets.

$10 /$ Net profit in percent of total equity.

$11 /$ Minus (-) indicates net open position.

12/ In 2002 figures include gross outstanding loans extended by banks. 2003 figures also include consumer finance companies. 2004 figures include special finance institutions. 2005 figures include credit card installments outstanding. 


\section{Box 2. Nonfinancial Corporate Sector Vulnerabilities}

The recovery of the Turkish economy since 2001 has been reflected in strong corporate sector performance. Yet, firms have had to rely to a large extent on bank credit and foreign borrowing, much of which has been extended in foreign exchange and at short maturities. The FSAP team examined a representative group of 20 Turkish firms listed on the ISE. These companies account for 37 percent of the market capitalization of all listed nonfinancial companies; their net sales are equivalent to 13 percent of GDP. For the aggregated balance sheet of these companies, 72 percent of total liabilities are of short term duration and nearly 60 percent are denominated in foreign currency or are exchangerate indexed - high by international standards. ${ }^{9}$

More detailed risk analysis offers some reassurance. Corporates' debt servicing ability is strong, as evidenced by a ratio of total liabilities to assets below 50 percent and interest coverage ratio of nearly 6 . Furthermore, current assets among these corporates are about three times as large as their net open foreign exchange position. These ratios are relatively high by international standards. The extent of risk, however, varies markedly by sector. Some sectors - notably the foodstuffs, energy, and metal and machinery industries - on average have relatively higher leverage, short term debt indicators, and foreign exchange exposure.

EDFs show a decline in recent years, reflecting reduced leverage and risk exposure in relation to the market value of assets. At end-March 2006, the one-year ahead EDFs for the selected Turkish corporates averaged 2.5 percent, and ranged from under 1 to 5 percent across sectors. However, scenario analysis suggests that risks can change sharply: volatility such as that occurred in May/June 2006 is estimated to roughly double EDFs.

\section{B. Stress Test Results}

\section{Stress test results indicate that the sector as a whole has substantial capital} buffers, but some large banks are vulnerable to major interest and credit quality shocks (Table 5 and Appendix II). A deterioration in credit quality would have a substantial impact on profits and, to a lesser extent, on regulatory capital. Most large banks would seem able to absorb the associated losses without falling below the required minimum CAR, but there could be problems for some. ${ }^{10}$ Liquidity risk appears to be small, although this hinges crucially on the liquidity of the sovereign bond market, should conditions deteriorate for the entire system.

\footnotetext{
${ }^{9}$ Similar results were obtained when the financial ratios of a larger sample of 66 large listed companies were analyzed.

${ }^{10}$ Because the domestic interbank market is limited, direct contagion effects are likely to be weak. Rather, banks might be affected by common shocks, or reputational effects affecting the cost of financing abroad.
} 
Table 5. Stress Test Results

\begin{tabular}{|c|c|c|}
\hline Risk factor & Magnitude of shock & $\begin{array}{l}\text { Impact on end-2005 } \\
\text { regulatory capital } \\
\text { (in percent) }\end{array}$ \\
\hline \multicolumn{3}{|c|}{ System CAR before shocks was 22.9 percent } \\
\hline \multicolumn{3}{|l|}{ A.Macroeconomic Shocks 2/ } \\
\hline (i) Sudden stop & $\begin{array}{l}2006 \\
2007 \\
2008\end{array}$ & $\begin{array}{l}-8.7 \\
-20.8 \\
-35.3\end{array}$ \\
\hline (ii) Oil Shock & $\begin{array}{l}2006 \\
2007 \\
2008\end{array}$ & $\begin{array}{r}-6.8 \\
-14.3 \\
-20.4\end{array}$ \\
\hline \multicolumn{3}{|l|}{ B. Trading Portfolio 3/ } \\
\hline \multirow[t]{3}{*}{ Interest Rate } & (i) YTL: +1500 bps; non-YTL: +1000 bps & -18.9 \\
\hline & $\begin{array}{l}\text { (ii) YTL: }+400 \text { bps s.e.; }+1500 \text { bps l.e.; } \\
\text { non-YTL: }+300 \text { bps s.e.; }+1000 \text { bps l.e. }\end{array}$ & -12.5 \\
\hline & $\begin{array}{l}\text { (iii) YTL: }+1500 \text { bps s.e.; }+400 \text { bps l.e.; } \\
\text { non-YTL: }+1000 \text { bps s.e.; }+300 \text { bps l.e. }\end{array}$ & -12.7 \\
\hline \multicolumn{3}{|c|}{ C. Entire Balance-Sheet and all Off-Balance Sheet Positions 4/ } \\
\hline \multirow{3}{*}{ Interest Rate } & (i) YTL: +1500 bps; non-YTL: +1000 bps & -40.7 \\
\hline & $\begin{array}{l}\text { (ii) YTL: }+400 \text { bps s.e.; }+1500 \text { bps l.e.; } \\
\text { non-YTL: }+300 \text { bps s.e.; }+1000 \text { bps l.e. }\end{array}$ & -26.5 \\
\hline & $\begin{array}{l}\text { (iii) YTL: }+1500 \text { bps s.e.; }+400 \text { bps l.e.; } \\
\text { non-YTL: }+1000 \text { bps s.e.; }+300 \text { bps l.e. }\end{array}$ & -20.2 \\
\hline \multirow[t]{2}{*}{ Interest Rate and Exchange Rate } & $\begin{array}{l}\text { (ii) YTL: }+400 \text { bps s.e.; }+1500 \text { bps l.e.; } \\
\text { non-YTL: }+300 \text { bps s.e.; }+1000 \text { bps l.e. } \\
\text { and YTL depreciation: } 45 \text { percent }\end{array}$ & -25.7 \\
\hline & $\begin{array}{l}\text { (iii) YTL: }+1500 \text { bps s.e.; }+400 \text { bps l.e.; } \\
\text { non-YTL: }+1000 \text { bps s.e.; }+300 \text { bps I.e. } \\
\text { and YTL depreciation: } 45 \text { percent }\end{array}$ & -18.0 \\
\hline \multicolumn{3}{|l|}{ D. Credit Portfolio 5/ } \\
\hline Global Portfolio & $\begin{array}{l}\text { Increase in PDs of all performing credits } \\
\text { of } 200 \text { percent }\end{array}$ & -10.7 \\
\hline Corporate Portfolio & $\begin{array}{l}\text { Increase in PDs of all performing credits } \\
\text { of } 400 \text { percent }\end{array}$ & -8.0 \\
\hline
\end{tabular}

Sources: BRSA, CBRT, Participating Credit Institutions, and FSAP Estimates.

1/ As evaluated on an end-of-period basis.

2/ Reported Impact on Regulatory Capital is an estimate at the sectoral level of reductions in capital relative to end-2005 levels

3 / Based on banks' estimates of the impact on the present value of their mark-to-market portfolio of interest sensitive items s.e.: short end of term structure; l.e.: long end of term structure.

4/ Based on banks' estimates of the impact on the (discounted) net cash flows on all interest sensitive items on and off-balance sheet

5 / Based on banks' estimates of the impact on expected losses of the shocks to credit quality

\section{Scenarios involving a sudden stop of capital inflows, a sudden reversal after a} credit boom, or a persistent large increase in oil prices are projected to threaten the profitability of some important institutions. Banking profits and eventually their capital are also highly sensitive to persistent increases in interest rates on YTL and domestically issued non-YTL instruments. 


\section{FinANCIAL SeCtOR Regulation AND INFrastructure}

\section{A. Liquidity Management and Intervention}

\section{Liquidity management and lender of last resort facilities}

22. The CBRT actively manages liquidity in the context of its inflation targeting framework. It has adequate facilities and procedures to manage overall liquidity and assist banks in normal times; interbank interest rates are steered using repurchase tenders, supported by standing facilities and reserve requirements. The CBRT Act provides ample flexibility in granting emergency lending assistance to financial institutions in periods of instability, and additional mechanisms to provide limited amounts of foreign currency liquidity. The authorities have yet to define a formal strategy for handling support in the case of liquidity crisis, including ensuring that protracted liquidity support is not granted to insolvent institutions.

23. The CBRT fully observes almost all provisions of the monetary transparency code, in the context of the formal inflation targeting framework regime introduced in January 2006 (Annex). The degree of observance of the Committee on Payment and Settlement Systems (CPSS) Core Principles for Systemically Important Payments Systems is also high.

\section{Bank intervention and resolution}

24. The Turkish authorities have made substantial efforts, mainly based on the 2005 BL, to establish more effective procedures for banking sector safety net and crisis management. However, some areas require further strengthening to ensure that the resolution of banks is made expeditiously and efficiently, if only to handle the inevitable exit of small, non-systemic banks as the sector evolves.

\section{Intervention and resolution powers}

25. The SDIF has responsibility for dealing with failing banks. However, the decision process for transferring such a bank from the BRSA to the SDIF should be accelerated, perhaps by amending the current requirement for a super-majority of the BRSA board before action can be taken. Furthermore, the SDIF needs to be fully integrated into contingency planning during difficult periods.

26. The ability of the SDIF to keep open a failing bank could entail large costs to the government. The SDIF may keep a bank open to seek its rehabilitation or resolution for up to 270 days (with a possible 90 day extension), without any clearly specified rationale. Using this option could incite a flight of deposits. Also, it is widely understood that, once a bank is operating under the SDIF's intervention, its depositors are protected in full, since it has become a state bank. Thus, keeping a bank open under the SDIF appears to generate a blanket guarantee, potentially leading to a large increase in ultimate resolution costs to the 
government. Regulatory measures should therefore be adopted to ensure that a transferred bank would remain open only in specified limited cases - for instance, if an investor is clearly at hand or extraordinary circumstances exist under which the closure of the bank could put at risk the stability of the banking system. Best international practice would be to make explicit that the objective of the responsible agencies is to find the solution that minimizes the cost to public funds and maintains the smooth functioning of the system as a whole. The efficient resolution of even small banks is important to avoid impairment of confidence or distracting the authorities from systemic issues.

27. The capacity of the judicial branch to interfere in, and even reverse, a bank liquidation process initiated by the BRSA remains an issue. ${ }^{11} \mathrm{~A}$ banking authority's decision to withdraw a bank's license and undertake its liquidation should be a definitive and irreversible administrative process.

\section{Deposit insurance}

28. The previous blanket deposit guarantee was replaced in 2004 by limited deposit insurance, managed by the SDIF. ${ }^{12}$ The development of procedures to ensure a faster repayment process of insured deposits could be helpful. Also, once confidence in the banking system has been further established, the authorities may wish to review whether the level of insurance should be revised downward.

29. The SDIF has made good progress in recovering assets taken over in the course of the resolution of the $\mathbf{2 0 0 1}$ crisis, but it is technically insolvent and its liquid reserves cover only a small fraction of the insured deposits. Since the insolvency is explained by interest accrued on loans obtained from the Treasury during the 2001 banking crisis, resolution of such loans would reassure depositors and signal that the episode has been closed.

\section{B. The Regulatory and Supervisory Framework}

\section{Main lessons and analysis of Basel Core Principles of Banking Supervision (BCP)}

30. Turkey has made impressive progress in updating its regulatory and supervisory framework to bring it further into line with international practice (Annex). The 2005 BL_-on which the IMF and the World Bank provided technical advice - and the associated sub-regulations have filled most gaps. Completing implementation, however, will take time. Meanwhile, the authorities have taken steps to improve supervisory practice, in keeping with priorities identified in the BCP assessment. The BRSA now prepares an annual supervisory

\footnotetext{
${ }^{11}$ Past experience with legal challenges to supervisory action reinforce this concern.

${ }^{12}$ Maximum coverage is YTL 50,000 per depositor, equivalent to about 7 times GDP per capita.
} 
cycle for each bank, and is developing capacity to conduct information systems and technology audits.

31. The authorities are taking steps to reinforce the banking system in the current favorable conditions. Recent positive moves include the decisions to request the maintenance of a minimum 12 percent CAR for all banks wishing to open a new branch (which already applied to banks with offshore affiliates), and to increase the rate of general loan loss provisions to 1 percent from 0.5 percent for new loans. ${ }^{13}$ A desirable next step would be to introduce a provision requirement on "special mention" loans; ${ }^{14}$ international practice suggests a provisioning rate of 2 to 5 percent may be appropriate. Banks' current profitability could easily support such additional provisioning.

32. The BRSA has legal authority and capacity to identify unsafe and unsound banking practices and request the adoption of corrective actions, but has not had recent occasion to demonstrate strong commitment to enforcement. In part because of experiences during the 2001 crisis, the BRSA still needs to build its reputation for rigorous correction of all deficiencies uncovered in the course of supervision. To this end, it would be valuable to define explicit criteria for timely and graduated action in coordination with the SDIF: during the 2001 crisis, delays in the resolution of several weak banks, reflecting a lack of mandatory triggers, increased the ultimate public cost of bank resolution.

33. The BRSA's capacity to effectively carry out its mandate of ongoing supervision is constrained. The agency lacks operational independence in certain budgetary and regulatory issues since the government can set limits on its expenditures budget, ${ }^{15}$ and has a role that may hinder the issuing of prudential sub-regulations.

34. Supervision of cross-border banking deserves more attention. The BRSA lacks Memoranda of Understanding (MOUs) with banking supervisors from the critical home countries of foreign banks operating in Turkey and with those in which Turkish banks have large operations. While informal procedures permit cooperation with some jurisdictions, the BRSA should intensify exchange of information and analysis with foreign supervisors (particularly those from EU countries).

35. A major challenge facing the BRSA, as for supervisors around the world, is to ensure that supervisory practice keeps up with developments in banking. The BRSA needs to ensure that it has the capacity to evaluate the increasingly complex risk management

\footnotetext{
${ }^{13}$ The forthcoming introduction of Basel II will establish a framework for supplemental capital requirements.

${ }^{14}$ Currently, loans that exhibit weaknesses, such as when the debtor faces negative trends in payment capability or substantial financial risks, yet are still performing, are termed "special mention" but no specific provisions are required.

${ }^{15}$ Banks, leasing, factoring, consumer finance institutions pay fees, up to a limit, but revenues do not accrue to the BRSA.
} 
procedures and risk models used by banks, motivated by both market forces and the introduction of Basel II (Box 3). Outsourcing validation would limit supervisors' ability to assess risks on a continuous basis.

\section{Box 3. Implementation of Basel II}

The Turkish authorities plan to implement Basel II as of January 2008, with the model-based approaches implemented one year later. The authorities will also take this opportunity to implement $\mathrm{VaR}$ models for the valuation of market risk.

The implementation of Basel II will affect banks' capital adequacy ratios and incentives. Capital requirements for the retail portfolio will be reduced as a result of the decrease in the risk weights of residential mortgages and other retail credits, which may prompt an expansion in lending to this sector. Additional capital requirements will be needed to cover significant investments in commercial interests; full deduction of such investments from capital will affect certain banks significantly. Banks have already begun to adjust their portfolios to reduce capital required under Basel II.

The stability analysis presented above suggests that the capital allocation to cover maturity mismatches deserves special attention. This may be particularly the case since the risk weight of longer-term housing loans will fall from 50 to 35 percent, making these loans even more attractive. More generally, the authorities may need to make use of the flexibility afforded under Pillar II to address those risk factors that are especially relevant to Turkish banks.

36. Cooperation among regulators needs to be further strengthened. The mechanisms of routine coordination, collaboration and sharing of information among functional supervisors and other agencies need further strengthening. The coordinating Financial Sector Commission (FSC) has met very rarely and may because of its diverse composition not discuss bank-specific matters; a sub-committee comprising just representatives of official agencies might be formed to work on detailed specific matters.

37. Better data management must remain priority. To support enhanced supervisory practice, the authorities need to make better use of the information that is already available, and, as needed and selectively, gather new types of information (e.g. on portfolio duration, corporate and household financial indicators, and dealings in derivatives as the activity develops).

\section{Anti-money laundering and countering the financing of terrorism (AML/CFT)}

38. The government has recently passed a number of key laws relating to antimoney laundering and combating terrorist financing (AML/CFT). A new money laundering offence was introduced in June 2005, and the stand-alone terrorist financing offence was introduced in July 2006. The new Law no. 5549 of October 2006 provides, 
among other things, for a more comprehensive system for disclosures of cross-border transactions of cash and monetary instruments

39. The Financial Action Task Force (FATF) noted these developments in its recent assessment of the implementation of AML/CFT standards. ${ }^{16}$ Nonetheless, the new legislation has not yet been in place long enough to fully demonstrate its effectiveness. Specifically:

- the number of suspicious transaction reports and convictions for money laundering is relatively low, and confiscation measures have also not yet produced substantial results;

- preventive measures requiring financial institutions to undertake customer identification and certain other measures do not fully meet the FATF standards for ongoing customer due diligence (CDD), identification of the beneficial owner, and enhanced CDD for highrisk customers and operations; and

- the framework for international co-operation is adequate, although certain limitations in the coverage of the money laundering and terrorist financing offences could provide a technical limitation to such assistance.

\section{Securities market regulation and supervision}

40. The CMB has adequate supervisory powers to monitor market institutions and market practice, and it has already achieved a fair degree of compliance with the International Organization of Securities Commissions (IOSCO) principles (Annex). Further improvements are on track. Amendments to the Capital Markets Law are expected to be submitted to parliament in 2008. In 2005 the CMB approved a well-designed Action Plan on harmonizing regulations with the EU acquis over the next two years. It is currently involved in a twinning arrangement with the German financial regulator. Key regulatory issues relate to the treatment of market conduct of large shareholders and corporate governance in publicly-owned corporations and securities market firms, which are often linked to banks. Another issue is improving the current system for valuing illiquid assets. The IOSCO and CPSS-IOSCO Securities Settlement assessments rated highly the infrastructure at the ISE and the settlement bank (Annex).

\section{Insurance sector regulation and supervision}

41. The insurance regulatory framework, including risk-based capital requirements, has been modernized. An early warning system introduced in 1997 has been used to identify financially weak companies and initiate on-site inspections and intervention action.

\footnotetext{
${ }^{16}$ A Report on Observance of Standards and Codes (ROSC) based on the FATF assessment will be issued to the Board.
} 
42. A modern insurance law has been presented to Parliament and is expected to be passed shortly. The law will deal with such issues as minimum capital, fit and proper requirements, direct licensing, and changes in control. Steps have been taken to introduce full EU solvency requirements and a close approximation to IFRS accounting. Regulatory matters that still need improvement include conglomerate supervision; market conduct; and coordination between licensing, offsite supervision and enforcement, and onsite inspections. It will also be critical to generate reliable data on the activities of the sector; the new Insurance Monitoring System is an important initiative to this end.

\section{Pension sector regulation and supervision}

43. The new voluntary system of individual pension saving plans is supported by a solid regulatory framework and effective supervision. The current supervisory focus on rule compliance should over time be replaced by an emphasis on internal control systems and ex-post assessment of good conduct. The lower limit on private pensions' investments in government securities and upper limit on offshore investments have recently been eliminated.

\section{Structural Issues}

44. Further financial deepening will contribute to the diversity and efficiency of the financial system, and ultimately enhance macroeconomic and financial stability. A comparison of the Turkish financial system with those of other emerging market countries suggests that there is still considerable scope for expanding intermediation and the availability of financial services (Figure 4).

\section{A. Banking Sector}

\section{State banks}

45. State banks have been put on a more commercial footing, and have lost privileged access to public sector deposits. Their remaining nonmarketable government securities - carrying an interest rate premium - are set to mature.

46. Bank privatizations is important to enhance efficiency and level the competitive playing field. To this end the initial public offering (IPO) for 25 percent of one public sector bank in May 2007 is an important step. The recent IPO at the foundation-owned bank means that that bank is also moving into the mainstream of bank corporate governance.

\section{Housing finance}

47. Housing lending may resume its rapid growth soon, particularly in the context of the 2007 Mortgage Law, which could, however, heighten certain risks. The law allows banks to charge floating rates on mortgages and prepayment penalties. It also allows banks to securitize their housing loans and thus spread some risk to others. However, securitization 
Figure 4. Credit and GDP per Capita

(GDP per capita in US\$ purchasing power parity terms versus credit to the private sector/GDP; all observations for 2005 except as noted)

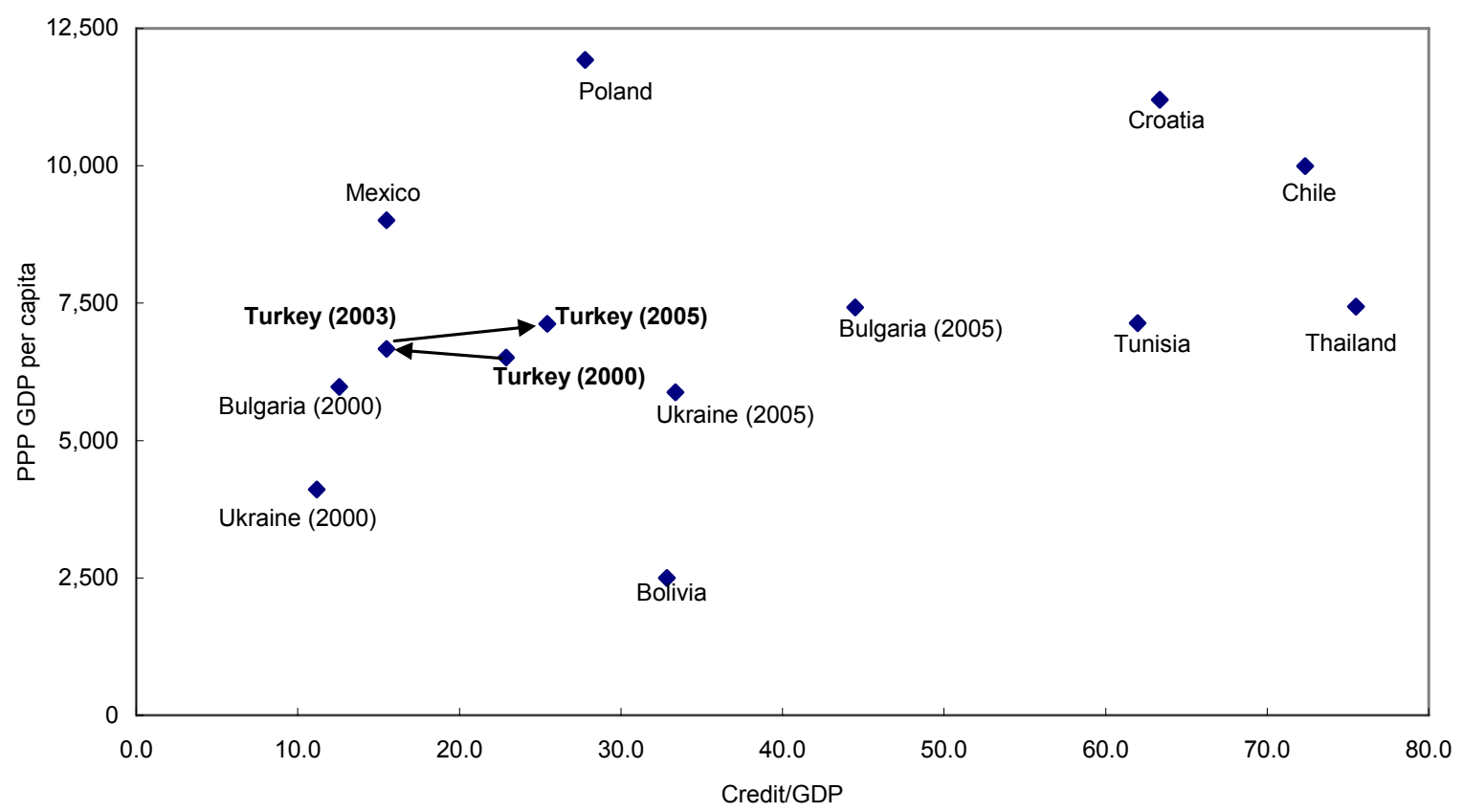

Source: IFS, World Bank, and staff estimates.

will take time to develop as housing titles will need to be improved and standard mortgage contracts introduced. Moreover, competition will tend to limit use of prepayment penalties, and floating interest rates mean that lenders need to pay even more attention to risk management.

48. The banks themselves will need to strengthen lending practices and employ good risk management, and the BRSA will need to supervise these practices. It is suggested that the BRSA should ensure that housing loans are granted on the basis of moderate loan to value ratios (e.g., 80 percent), monthly payments do not exceed $25-30$ percent of borrowers' well-documented income, and exotic (subprime) mortgages are avoided. In this connection, the authorities' scheme for the allocation of supervisory responsibilities seems broadly appropriate: the BRSA will be in charge of supervising primary lending, which includes the Housing Finance Corporations (banks, leasing companies and consumer finance companies), while the CMB will be in charge of supervising securitization of housing loans, as well as Mortgage Finance Companies. Coordination and information exchange will be key. 


\section{B. Nonbank Financial Institutions}

\section{Securities markets}

49. Security market development will depend on sustained macroeconomic stability and further microeconomic and regulatory changes. Despite improvements, investors remain deterred by long memories of past deficiencies in these areas.

50. Concerns about information quality and the potential market role of large corporate owners may be deterring market participation. The authorities have attempted to improve information quality. However, non-listed companies still often need to improve their accounting practices to reach CMB standards, which in most areas reflect international best practice. Also, identifying the ownership and location of decision making in corporations is often difficult, despite the CMB's attempts to increase transparency. Although major shareholders and board members must disclose "significant events," this requirement may leave room for interpretation and delays. Furthermore, market participants cite concerns that minority shareholders are not well protected from actions by controlling shareholders.

51. In this connection, the current endeavor to draft a new Commercial Code is commendable. The code should strengthen aspects of corporate governance, including: enforcement action; accountability of board members; a presumption of due diligence on the part of board; fit and proper criteria for board members other than level of education; permitting legal entities to be represented on boards; permitting legal entities to exercise voting rights related to their equity shareholdings; a one-share-one-vote rule; and a broader interpretation of minority shareholder protection.

52. The ISE's status as an autonomous government agency could create regulatory overlaps and limit its future ability to provide internationally competitive services. The government needs to ensure that: (i) the governance of the ISE allows it to remain competitive and cost-effective; (ii) sufficient capital is available for investment in technology and related areas; and (iii) the quality of the regulatory function is maintained - there is now the possibility of some overlap between the CMB and the ISE. Issues impeding the ISE privatization need to be resolved soon lest it lose out in the increased competition among exchanges in Europe. On a related point, the development of the money market would be helped by greater standardization of repo contracts, and more competition between the ISE and the over-the-counter market by lowering registration costs.

\section{Public debt management}

53. The institutional framework established under the 2002 Law on Regulating Public Finance and Debt Management (Law 4749) appears to be well designed and implemented. The strategy of extending maturities and shifting further towards local-currency financing should reduce vulnerabilities and contribute to financial sector deepening, facilitating effective debt management. The Treasury recently successfully issued inflation-linked bonds, 
and plans regular quarterly issues. Such securities can help extend the maturity of domestic currency debt, and generate significant cost savings where confidence in continued price stability is not yet fully established. The Treasury has been issuing 5 year fixed coupon bonds monthly since the beginning of 2007, and in March 2007 issued a 7 year floating rate bond. The Treasury should increasingly seek to integrate asset and liability management, for example, by inviting banks to tender for deposits of the Public Depository System now that the state-owned banks have lost their monopoly.

\section{The pension system}

54. The authorities had planned a reform of social security pensions to contain their fiscal cost and over time expand the scope of worker participation in the voluntary pillar, but the plans have been rejected by the Constitutional Court. The authorities are now devising an alternative reform that could achieve these benefits while recognizing the concerns of the Court.

55. The changes in the private pensions included in the proposed Insurance Law are highly desirable and will broaden the system. The changes will allow enrollees in corporate pension funds to transfer to the private system as a group. Moreover, such pensions will be "vested" earlier, and will follow the worker through job changes in the formal sector.

\section{Credit Information and the Legal Framework}

56. The Credit Bureau of Turkey (KKB) generally performs well, but could expand its information sources. The KKB plans to expand its operations to the corporate sector; inclusion of data from leasing companies and credit cooperatives would be desirable. The KKB could also expand its sources of information to include, for example, data on payments to utility companies, to help those outside the financial system gain a reputation for prompt repayment and qualify for bank loans.

57. Problems in creating collateral and executing creditor rights affect the volume of lending. Taxes and fees for creating collateral are high relative to other countries in the region. ${ }^{17}$ The Turkish Cadastre and Registration General Directorate could improve the system by modernizing land titling and registration systems, and developing a property valuation system. The Turkish judicial system is generally well-regarded and probably at least as efficient as those in most comparable countries. Perennial problems, however, relate to the limited expertise of the judiciary in financial matters and court congestion, despite recent efforts in these areas. In addition, Creditors are penalized by heavy taxes on collection (in some cases as high as 32 percent) and are legally prohibited negotiating solutions directly. These problems are likely to increase with the growth of mortgage lending.

\footnotetext{
${ }^{17}$ World Bank, Doing Business Indicators, various years.
} 
58. A new bankruptcy law was put into effect in 2003. It included the possibility of suspending bankruptcy proceedings in cases where companies might emerge from bankruptcy (similar to U.S. Chapter 11 bankruptcy proceedings). However, the determination of the eligibility of an applicant for this procedure, and the management of assets while the applicant is under this protection, have proven to be complex. Further review in the light of this experience would seem warranted. 


\section{ANNEX: OBSERVANCE OF FinANCIAL SECTOR STANDARDS AND CODES-SuMMARY AsSESSMENTS}

The annex contains summary assessments of international standards and codes relevant for the financial sector. The assessment has helped to identify the extent to which the supervisory and regulatory framework is adequate to address potential risks in the financial system.

The following detailed assessment of financial sector standards were undertaken: Code of Good Practices on Monetary Policy Transparency by Mr. Hardy (IMF); the BCP for Effective Banking Supervision by Mr. Cortavarria, Ms. Mitchell-Casselle (both IMF), Ms. Nieto (Bank of Spain), and Mr. Lind (Swedish Riksbank); the IOSCO Objectives and Principles of Securities Regulation assessed by Mr. Dankers (Netherlands Authority for Financial Markets); and the CPSS and CPSSIOSCO Core Principles by Mr. Keppler (World Bank).

The assessments were based on the self-assessments undertaken by Turkish authorities, a review of relevant documents, and discussions with the Turkish authorities, market participants, and industry associations on actual practices.

Turkey's observance of international financial sector standards and codes is generally strong, though in each area certain aspects were identified where further improvements would be desirable. The Turkish authorities are aware of the areas that need further reforms and are in the process of addressing them.

\section{Observance of The Code of GoOd Practices on Transparency in Monetary POLICY}

\section{General}

59. This assessment covers the transparency of monetary policy in the Republic of Turkey, and in particular its formulation and implementation by the CBRT in the context of the government's overall economic strategy. It forms part of the FSAP for Turkey, which was conducted jointly by the IMF and the World Bank, and was undertaken mainly during a mission in April 2006, with additional discussions thereafter and during a mission in September 2006. ${ }^{18}$

60. The assessment is based on information available in April 2006, and specifically on a review of relevant laws and regulations then in force; publications issued by the Turkish authorities, and material posted on websites; the authorities' response to a questionnaire and their self-assessment of observance of the code; and discussions held with the Turkish authorities - mainly from the CBRT - and representatives of the private financial and nonfinancial sector during the FSAP missions. The most important document underlying the

\footnotetext{
${ }^{18}$ The main assessor was Mr. Daniel Hardy of the Monetary and Capital Markets Department of the IMF.
} 
assessment is the Law on the CBRT Law, Law No. 1211, first passed on January 14, 1970, and most recently amended on April 25, 2001 by Law No. 4651 and on October 19, 2005 by Law No. 5411 (the BL). Extensive use was made also of other CBRT documents such as the "General Framework for Inflation Targeting Regime and Monetary and Exchange Rate Policy for 2006" of December 2005. The authorities cooperated fully, and generously provided materials and time for discussion.

\section{Main findings}

61. The level of monetary policy transparency is generally high. The letter of the law, regulations and practices established by the CBRT, and the practice of how laws and regulations are implemented all contribute to this result. The CBRT's primary objective of achieving and maintaining price stability is embedded in law, as are the CBRT's broad powers to define and deploy monetary instruments to achieve that objective. The CBRT makes extensive efforts to explain its objectives and decision-making, and mechanisms are in place to ensure accountability.

62. The 2001 amendment of the CBRT Law gave the CBRT substantially greater independence in the implementation of monetary policy and freed it of any obligation to finance the public sector. The CBRT has used this independence to develop an inflation targeting framework and procedures; the authorities introduced a formal inflation targeting framework from the beginning of 2006. The inflation target itself is set jointly by the CBRT and the government. Various means, such as a periodic inflation report, are used to explain the objective and measures used to achieve it. The CBRT is accountable to the government and to the Grand National Assembly of Turkey. However, a lacuna in the CBRT Law is lack of specificity concerning the removal from office of members of the governing bodies on grounds of physical or mental incapacity, for malfeasance, or on other grounds.

63. Relations between the central bank and government are well defined. The CBRT acts as financial and economic advisor, fiscal agent and treasurer for government, but may not provide direct credit or purchase government securities in the primary market. However, the CBRT may provide advances to the SDIF and via the Export Credit Bank; amounts outstanding are currently low. Furthermore, there are no explicit requirements or mechanisms to maintain the capital of the central bank, although to date this does not appear to have been an issue.

64. Information on the specification and use of the CBRT's monetary instruments is readily available, as is information on data reporting requirements. The timely release of explanations of the decisions of the Monetary Policy Committee, frequent press briefings and public addresses by senior staff, and the extensive program of publication of statistics and economic analysis helps ensure that the stance of monetary policy is well understood relative to the CBRT's objectives and the current economic situation. However, there is no presumption in law that consultations will be undertaken when monetary instruments are modified, nor that any consultations will be public; in practice consultation seems to have been limited. 
65. Turkey has subscribed to the Special Data Dissemination Standards since 1996. The CBRT regularly publishes its own detailed balance sheet and income statement, which is independently audited on an annual basis. Information on internal audit functions, staff regulations, and legal protection of staff for actions taken in the course of their duties is publicly available.

66. The culture of monetary policy transparency established by the CBRT seems to be well entrenched. A challenge for monetary policy transparency might arise over the medium term if economic conditions worsened considerably and the CBRT came under increased political pressure to pursue conflicting objectives - a possible scenario that might be faced by any monetary authority.

67. Recommended actions to improve monetary policy transparency are limited, and none are urgent. Among these recommendations, the most important is the establishment of processes for public consultation on changes to monetary policy instruments and arrangements. Several other recommendations will require amendments to the CBRT Law in order to be implemented; they do not appear to warrant placement at the top of the legislative agenda at this time.

\section{Table 6. Recommended Plan of Actions to Improve Observance of IMF's MFP Transparency Code Practices-Monetary Policy}

\begin{tabular}{|l|l|}
\hline \multicolumn{1}{|c|}{ Reference Practice } & \multicolumn{1}{|c|}{ Recommended Action } \\
\hline $\begin{array}{l}\text { 1.1.7 The procedures for appointment, } \\
\text { terms of office, and any general criteria } \\
\text { for removal of the heads and members of } \\
\text { the governing body of the central bank } \\
\text { should be specified in legislation. }\end{array}$ & $\begin{array}{l}\text { In due course, the CBRT Law should be amended to } \\
\text { secify in more detail the conditions under which the } \\
\text { Governor, Vice Governors, or members of the governing } \\
\text { bodies may be removed from office. }\end{array}$ \\
$\begin{array}{l}\text { 1.2.2 The amounts and terms of credits, } \\
\text { advances, or overdrafts to the } \\
\text { government by the central bank and those } \\
\text { of deposits of the government with the } \\
\text { central bank should be publicly } \\
\text { disclosed. }\end{array}$ & $\begin{array}{l}\text { The condired be given to staggering the terms of office of the } \\
\text { Vice Governors in order to ensure continuity. }\end{array}$ \\
\hline
\end{tabular}




\begin{tabular}{|c|c|}
\hline Reference Practice & Recommended Action \\
\hline $\begin{array}{l}\text { 1.2.5 The manner in which central bank } \\
\text { profits are allocated and how capital is } \\
\text { maintained should be publicly disclosed. }\end{array}$ & $\begin{array}{l}\text { In due course, provisions and obligations on the } \\
\text { maintenance of capital should be specified in the CBRT } \\
\text { Law. }\end{array}$ \\
\hline $\begin{array}{l}\text { 2.5 For proposed substantive technical } \\
\text { changes to the structure of monetary } \\
\text { regulations, there should be a } \\
\text { presumption in favor of public } \\
\text { consultations, within an appropriate } \\
\text { period. }\end{array}$ & $\begin{array}{l}\text { The CBRT should establish a procedure for public } \\
\text { consultations with banks, other financial institutions, and } \\
\text { others on proposed substantial technical changes to the } \\
\text { structure of monetary regulations. }\end{array}$ \\
\hline $\begin{array}{l}\text { 4.2.1 The financial statements should be } \\
\text { audited by an independent auditor. } \\
\text { Information on accounting policies and } \\
\text { any qualification to the statements should } \\
\text { be an integral part of the publicly } \\
\text { disclosed financial statements. }\end{array}$ & $\begin{array}{l}\text { In due course, the CBRT Law should be amended to make } \\
\text { an independent audit mandatory. }\end{array}$ \\
\hline
\end{tabular}

\section{Authorities' response}

68. Central Bank of the Republic of Turkey finds all the FSAP assessments, findings and recommendations very valuable and beneficial. The CBRT is also pleased that the level of monetary policy transparency in Turkey is found as "generally high" by the FSAP team.

\section{We broadly agree with findings of the FSAP team and we would like to mention that in near future your assessments will be taken into account considering the following points:}

- We would like to point out that these advances can be utilized by SDIF under extraordinary conditions as stated in the related law. Therefore, it is very difficult to set definite conditions in advance. But the CBRT agrees that publicizing the conditions (maturity, amounts, repayment conditions, interest rates) of such advances to the SDIF helps to enhance its efforts in transparency. However, there is no outstanding balance for the time being and the CBRT will consider publicizing such information in the future.

- Currently CBRT undertakes unofficial consultations for proposed substantive technical changes to the structure of monetary regulations with the relevant organizations and banks. However, the CBRT is planning to establish a procedure for such public consultations. 


\section{Basel Core Principles for EfFective Banking SUPERVision ${ }^{19}$}

\section{Information and methodology used for assessment}

70. The assessment of observance of the BCP was based on a review of relevant laws, regulations and other guidelines related to the financial sector; documentation of supervisory practices; and discussions with the BRSA and other relevant authorities and stakeholders. The assessment takes into account the new regulations issued in November 2006 to implement the BL No. 5411 of October 19, 2005, while recognizing that implementation of the new regulations through a full supervisory cycle could not have been achieved at the time the assessment was completed. The assessment takes into account measures taken by the BRSA in the course of the FSAP process, some of which accord with the preliminary recommendations made. The BCP team received very good cooperation from the Turkish authorities and the private sector. The assessment takes into consideration comments received from the authorities through March 2007.

71. The team received the BRSA's self-assessment, which, however, was undertaken before the issue of the new regulations. Once the new regulatory framework has been fully implemented, the BCP team suggests that the BRSA commissions an assessment by an external team of assessors (not necessarily from the Fund and Bank) or performs a new self-assessment based on the new BCP methodology which includes more rigorous essential criteria in certain key areas, suitable for a modern banking system.

\section{Institutional and market structure—overview}

72. The Turkish financial system is dominated by the $\mathbf{5 0}$ banks, including three large public sector commercial banks and 18 majority foreign-owned banks. All banks are subject to the same regulatory and supervisory regime. Many banks are affiliated with NBFIs, and some have links to non- financial corporations. Group structures complicate regulation and supervision in such areas as connected lending, large exposure limits, regulatory arbitrage, and consolidated supervision.

73. Banking regulation and supervision is exercised by the BRSA, based on the BL and secondary sub-regulations. The BRSA has also responsibility for regulating and supervising financial leasing, factoring and consumer financing companies. The SDIF provides deposit insurance and has a leading role in bank resolution and liquidation. The CBRT is the monetary authority, and securities market oversight is exercised by the CMB.

\footnotetext{
${ }^{19}$ The assessment was conducted by Ms. Greta Mitchell-Casselle and Mr. Luis Cortavarria, IMF staff; Ms. Maria J. Nieto, banking regulation expert, Bank of Spain; and Mr. Göran Lind, banking regulation expert, Swedish Riksbank.
} 
General preconditions for effective banking supervision

\section{Macroeconomic stability}

74. Improvements in monetary and fiscal policy and the overall policy framework have contributed to much better macroeconomic performance over recent years, and a strengthened financial system. Growth has been strong and inflation has fallen to the lowest level in decades. Money and especially credit stocks have recovered. Banks have rebuilt capital to comfortable levels, bank profitability has been restored, and the NPL ratio has declined. Good prospects have attracted large-scale foreign direct investment into the banking sector, and Turkish banks have been able to obtain financing abroad at advantageous rates.

\section{Public infrastructure}

75. While Turkey has a reasonably independent judicial system, there is a history of the judicial branch amending and even reversing bank liquidation processes. Moreover, banks can sue to block monetary fines imposed by the BRSA. As in many other countries, prosecuting technically complex financial cases may be problematic due to a shortage of relevant expertise in the judicial system.

76. The BL established a framework for corporate governance in banks, and subregulations have recently been issued in this area, e.g., on internal controls and audit and on corporate management principles. Banks' accounting practices are required to meet standards that are compliant with IFRS and International Accounting Standards (IAS). Other corporations listed on the Istanbul Stock Exchange are required to publish fairly complete accounts; as in other countries, information on smaller companies' finances is less readily available.

\section{Payment system}

77. Turkey is in observance of the great majority of the provisions of the CPSS Core Principles for Systemically Important Payments Systems. The main outstanding issues relate to full legal certainty in settlement in the national check clearing system, and, as yet, no explicit set of failure-to-settle mechanisms.

\section{Financial safety nets, crisis management, and bank resolution}

78. The CBRT has adequate facilities and procedures to manage overall liquidity and assist banks in normal times, and flexibility for it to grant emergency lending assistance to financial institutions in periods of instability. However, a formal strategy for handling support in the case of a liquidity crisis has yet to be designed. The deposit insurance scheme currently covers all depositors in all locally-incorporated banks up to a limit of YTL 50,000 (about US\$35,000) each. 
79. The BL codifies procedures for bank intervention, resolution and crisis management, but current provisions could lead to delays and higher overall costs in closing weak banks. Guidelines are lacking that would ensure that appropriately graduated action is taken in a timely fashion, and that a bank transferred to the SDIF would remain open only in limited and highly specified cases.

\section{Main findings}

\section{Overall conclusions}

80. The authorities are to be commended for extensive work on the new BL and the recent improvements in prudential supervision, but considerable work is still needed to fully meet the supervisory requirements of the rapidly evolving Turkish banking system. The BRSA has reacted positively to a number of significant recommendations included in earlier FSAP mission discussions. Nevertheless, newly issued sub-regulations and communiqués need to be implemented by the supervised entities and the BRSA's supervisory framework enhanced accordingly.

\section{Objectives, autonomy, powers and resources (Core Principle (CP) 1)}

81. In practice the BRSA lacks full operational independence in regulatory and budgetary matters. Before issuing a regulation, the BRSA must conduct consultations with the related Ministry and the Undersecretariat of the State Planning Organization. While nonbinding consultation is appropriate, the process is perceived as binding, thus raising the possibility of undue government interference. Moreover, the related Ministry is legally empowered to file a lawsuit for the cancellation of the Board's regulatory decision. The BRSA should remain the final decision maker regarding the text of sub-regulations. All visits abroad by the BRSA management or staff, such as for on-site inspections or for training, must be approved by the government. BRSA's funding comes from fees assessed on supervised institutions. However, the BRSA is not free to use these funds in an independent manner since the government sets annual limits in the expenditures' budget.

82. The BRSA has difficulty recruiting and retaining staff with expertise in some areas of banking supervision, information technology, stress testing, and assessment of banks' contingency planning and evaluation of financial models. This is another example of the impact of budgetary constraints placed on the BRSA. Staffing shortages have become more acute by the recent extension of the BRSA's mandate to cover certain NBFIs.

Moreover, the validation of internal models in banks to assess market and credit risks and the forthcoming introduction of Basel II, will require new skills of supervisors. The training of the BRSA staff has started, but needs to be substantially strengthened.

83. Legal protection is provided to BRSA management and staff against lawsuits brought against them for actions taken in good faith in the exercise of their responsibilities. Individuals are shielded from civil actions in that such actions are deemed to have been brought against the BRSA, and may only be recoursed if they acted in "default." 
Legal costs incurred in defending against legal actions are covered by the BRSA (up to a cap). In the case when criminal offenses are alleged to have been committed by the BRSA Board and its Chairman, or by its staff, the relevant minister or the BRSA Chairman, respectively, has the legal power to authorize or veto an investigation. While this provision in practice provides an extra layer of protection, it could lead to conflicts of interest, in particular for the BRSA Chairman. The exercise of this power should be guided by internal guidelines.

84. Cooperation among regulators needs to be further strengthened. The coordinating FSC has met very rarely, and may because of its composition not discuss bankspecific matters. The mechanisms of routine coordination, collaboration and sharing of information among functional supervisors and other agencies seem weak. In particular the division of work and the sharing of analyses between the BRSA and the SDIF need to be clarified. A MoU with the CMB should be concluded.

\section{Licensing and structure (CPs 2-5)}

85. Although the BRSA uses conservative accounting criteria for the recording of banks' investments in insurance companies and other financial companies, ex ante approval of the investments in these companies is not required. Therefore, there is potential for corporate affiliations or structures to impede effective supervision, and supervisors cannot evaluate from the outset if a bank has adequate financial and organizational resources to handle a potential acquisition/investment. As a general policy, the Treasury and the CMB reportedly seek the BRSA's opinion in the approval process for the acquisition by a bank of an insurance company or an institution operating in capital markets that are not under the regulation and supervision of the BRSA, but the BRSA should not have to rely on information provided by other authorities.

\section{Prudential regulations and requirements (CPs 6-15)}

\section{Large improvements have taken place lately, although there are still a few} prudential norms and supervisory practices that are not fully in line with international best practices. Recently issued sub-regulations need to be implemented fully by banks, and the BRSA's supervisory framework enhanced accordingly. Moreover, the effectiveness of prudential regulation is limited by the absence of certain sub-regulations, such as on country and transfer risk and interest rate risk in the banks' books. There are concerns about Turkey's identification of beneficial owners. While the BCP team could not determine the full extent or magnitude of this problem, it nevertheless highlights potential weaknesses in the capacity of banks and supervisors to identify the full extent of excessive concentration of credits, the degree of compliance with prudential norms to mitigate risks and to conduct consolidated supervision. 
87. There is an appropriate limit on exposures to groups of borrowers who constitute "risk groups," but limits on exposure to insiders are relatively generous. As prescribed by the BL and in line with sound international practices, banks apply a limit of 20 percent of own funds for the aggregate exposures to large shareholders and to other connected parties. However, banks are also allowed to apply a higher limit of 50 percent for the aggregate exposures to large shareholders and other connected parties plus exposures to small shareholders. This limit is in excess of international practices and should be lowered to the 25 percent limit applicable to groups of borrowers not connected to the bank, or less.

88. In line with international best practices, the BRSA supervisors have now introduced "forward-looking" criteria when assessing loan quality. More internal guidance on the use of such "forward-looking" criteria should be developed to support the on-site inspectors' efforts. Also, commencing with the 2007 supervisory cycle, supervisors should routinely perform rigorous assessments of banks' credit policies when inspections lead to substantial amounts of loans to be reclassified. Loans classified as Group 2 exhibit specific weaknesses such as negative trends in borrowers' repayment capacity, which indicate that full and timely repayment may not be forthcoming. Therefore, specific provision should be set aside for Group 2 loans. It is also important that deficiencies in banks' classification practices are remedied promptly, if necessary through BRSA enforcement actions.

89. The BRSA has taken important measures to improve its oversight of market risks. However, more work is called for in order to improve its capacity to monitor the complex market activities of banks through additional training opportunities for supervisors in assessing market risks and validating banks' VaR models.

90. Turkey amended the Prevention of Laundering Proceeds of Crime Law (No. 5549) on October 11, 2006. Considering that AML issues constitute a main operational risk for banks, the BRSA should ensure that relevant AML aspects, in compliance with BCP and the Financial Action Task Force standards are fully incorporated into the supervisory process. When carrying out its supervisory responsibilities, the BRSA should have access to any suspicious transaction report documentation necessary to assess the adequacy of reporting and compliance with the legal framework. In addition, banks should report suspicious activities and incidents of fraud to the BRSA when they are material to the safety, soundness or reputation of the bank.

\section{Methods of ongoing supervision (CPs 16-20)}

91. The BRSA should be commended for having introduced a full supervisory cycle in line with international best practices, even if challenges remain in its implementation. Moreover, the BRSA has enhanced its tools and capacity to monitor information systems in banks and to provide more data-based structured support to the supervisory staff. However, documentation from the on-site supervision process is fragmented, in that the main inspection report does not contain the findings of other examinations of the same bank conducted during the same supervisory cycle. Furthermore, inspection reports are not 
adequately focused on analyses and judgments. The main examination report by the on-site team should always contain a list of recommendations and orders (whenever there are such) to the bank, in a prioritized order. Unless the BRSA Board disagrees, this is the list that the Enforcement Department should follow. Finally, the work of some off-site and enforcement functions are not seamlessly integrated in the supervisory process.

92. Another major challenge is consolidated supervision and surveillance of mixed conglomerates. Work in this area would include the full implementation of the recently issued sub-regulations on consolidation of financial and non-financial companies in line with the IFRS, and those on supervision of financial conglomerates in line with the EU Directive on the Supplementary Supervision of Credit Institutions, Insurance Undertakings and Investments Firms in a Financial Conglomerate. The BRSA has not yet adopted a general policy or practice to conduct an "integrated" supervision inspection of an entire banking group, assessing the potential effects on the bank emanating from the other entities. It does not regularly request information, such as inspection reports, from other domestic supervisors for securities firms and insurance companies. Moreover, it does not regularly obtain and analyze information on banks' parent companies and, when relevant, the parent's affiliates.

\section{Remedial measures (CP 22)}

93. The enforcement process may lead to undue delays and neglect of possibly controversial, but nevertheless important, elements of the recommendations from the on-site inspectors. The integration between on-site supervision and the enforcement functions is not transparent, and this might to lead to warranted supervisory actions being delayed or not undertaken. The supervisors are reluctant to initiate action unless a bank has breached one of a small number of predetermined quantitative limits. In addition, the courts impede BRSA's powers to take appropriate remedial measures.

\section{Cross-border banking (CPs 23-25)}

94. Informal or formal cooperation arrangements are not in place with all countries in which Turkish banks have major operations or with all home countries of banks with a large presence in Turkey. In the absence of such arrangements, the BRSA is reluctant to develop relations with foreign supervisors from these countries. The BRSA should include in the supervision of the bank group the foreign affiliates of supervised entities on a fully consolidated basis, including assessing the potential risks, such as reputational and legal risks, on the parent bank emanating from the foreign operations.

\section{Recommended Action Plan}

95. Unless otherwise noted, the BCP team recommends that the BRSA should take actions within one year to address the areas identified below. 
Table 7. Recommended Action Plan to Improve Compliance with the BCP

\begin{tabular}{|l|l|}
\hline \multicolumn{1}{|c|}{ Reference Principle } & \multicolumn{1}{|c|}{ Recommended Action } \\
\hline BCP 1.2. Independency of the & $\begin{array}{l}\text { The legislation needs to be amended to allow the BRSA to be } \\
\text { fully responsible for managing its expenditures budget } \\
\text { without consulting the relevant Minister and, in general, any } \\
\text { interference from the government. Thus, the BRSA should } \\
\text { have the right to decide when management or staff should } \\
\text { travel outside Turkey for on-site visits of banks or for staff } \\
\text { training. There should be no interference from the } \\
\text { government in the passing of sub regulations issued by the } \\
\text { BRSA in accordance with prescribed legal procedures and } \\
\text { national law. The BRSA should have the final decision on all } \\
\text { technical issues related to its relevant sub-regulations. }\end{array}$ \\
$\begin{array}{ll}\text { The BRSA should expand its efforts to retain staff with more } \\
\text { banking and supervision experience. In particular, it should } \\
\text { take additional measures, including obtaining budgetary } \\
\text { means, to hire sufficient numbers of staff of adequate } \\
\text { expertise to handle the recently added supervisory } \\
\text { responsibilities for NBFIs. }\end{array}$ \\
\hline $\begin{array}{l}\text { BCP 1.6. Arrangements for sharing } \\
\text { information between supervisors }\end{array}$ & $\begin{array}{l}\text { The BRSA, together with the other financial regulatory } \\
\text { authorities, should work to strengthen, formally as well as in } \\
\text { practice, cooperation and information sharing. }\end{array}$ \\
$\begin{array}{l}\text { The bilateral MoU between the BRSA and SDIF should be } \\
\text { amended to further specify the scope and purposes of each } \\
\text { agency's activities to avoid gaps and overlaps. It also needs } \\
\text { to be more specific on information sharing, in particular } \\
\text { during potential or real crisis situations. }\end{array}$ \\
$\begin{array}{l}\text { The BRSA should conclude a MoU with the CMB to } \\
\text { improve coordination and information sharing. }\end{array}$ \\
$\begin{array}{l}\text { The FSC needs to establish a subcommittee composed only } \\
\text { of the public regulatory and supervisory agencies to } \\
\text { exchange and discuss institution specific information. } \\
\text { Alternatively, if legally necessary, a parallel committee to the } \\
\text { FSC consisting of these parties should be established. }\end{array}$ \\
\hline
\end{tabular}




\begin{tabular}{|c|c|}
\hline Reference Principle & Recommended Action \\
\hline BCP 5. Investment Criteria & $\begin{array}{l}\text { The BL or sub regulations need to be amended to empower } \\
\text { the BRSA to require prior permission if a bank wants to } \\
\text { establish or acquire a financial institution as a subsidiary. } \\
\text { The BRSA should continue to assess whether the bank has } \\
\text { the financial and managerial capabilities to handle the new } \\
\text { subsidiary. It should also continue to ensure that the new } \\
\text { structure will not impede effective supervision. }\end{array}$ \\
\hline BCP 7. Credit Policies & $\begin{array}{l}\text { The BRSA should ensure that it assesses the appropriateness } \\
\text { and implementation of bank credit policies in particular in } \\
\text { those cases where inspectors require banks to reclassify } \\
\text { material amounts of loans. In such cases, the BRSA should } \\
\text { also perform an even more rigorous assessment of a bank's } \\
\text { credit policies and implementation of them. } \\
\text { The BRSA should ensure that banks have appropriate } \\
\text { standards and credit information when lending to the } \\
\text { household sector, to SMEs and conglomerates and require } \\
\text { them to take appropriate measures to correct deficiencies in } \\
\text { this area. }\end{array}$ \\
\hline $\begin{array}{l}\text { BCP 8. Loan Evaluation and Loan } \\
\text { Loss Provisioning }\end{array}$ & $\begin{array}{l}\text { The sub regulation on loan classification and provisioning of } \\
\text { loans should be amended to provide for specific provisioning } \\
\text { for loans in the special mentioned category. } \\
\text { The BRSA should encourage its supervisory staff to continue } \\
\text { to further the use of "forward-looking" criteria for classifying } \\
\text { loans, e.g., by issuing an internal list of examples of such } \\
\text { criteria, such as cash flow calculations, weak geographical or } \\
\text { macroeconomic sectors, or weak connected companies or } \\
\text { shareholders. } \\
\text { The BRSA should also continue to ensure that supervisory } \\
\text { staff retains up-to-date skills on loan evaluation techniques. }\end{array}$ \\
\hline BCP 9. Large Exposure Limits & $\begin{array}{l}\text { The BRSA should ensure that banks implement risk } \\
\text { management procedures to identify all beneficial owners and } \\
\text { effectively monitor concentrations of credit and adherence to } \\
\text { prudential risk limits. (Also applicable for CP 10). }\end{array}$ \\
\hline
\end{tabular}




\begin{tabular}{|c|c|}
\hline Reference Principle & Recommended Action \\
\hline BCP 10. Connected Lending & $\begin{array}{l}\text { The BRSA should ensure that banks implement risk } \\
\text { management procedures to identify all beneficial owners of } \\
\text { other financial and non-financial companies and effectively } \\
\text { monitor concentrations of credit and adherence to prudential } \\
\text { risk limits. } \\
\text { To meet the additional criteria for this CP, the BL should be } \\
\text { amended to ensure that the aggregate limit for exposures to a } \\
\text { bank's insiders (including both small and large shareholders) } \\
\text { should not be higher than the } 25 \text { percent limit set for } \\
\text { exposures to other groups of connected borrowers (not } \\
\text { related to the bank). The recently enacted sub-limit of } \\
20 \text { percent for exposures to large shareholders and other } \\
\text { connected parties should be maintained. }\end{array}$ \\
\hline BCP 11. Country Risk & $\begin{array}{l}\text { The BRSA should issue explicit regulations and guidelines } \\
\text { which address gaps in the supervisory framework for country } \\
\text { risk, and fully implement them. }\end{array}$ \\
\hline BCP 12. Market Risk & $\begin{array}{l}\text { The BRSA should continue to improve its capacity to } \\
\text { monitor the complex market activities of banks through } \\
\text { additional training opportunities for supervisors in assessing } \\
\text { market risks and validating banks' VaR models. } \\
\text { The BRSA should proceed to include in its work plan for } \\
2007 \text { the inspection of banks' implementation of the new } \\
\text { market risk sub-regulations. } \\
\text { The BRSA should proceed to introduce the computer- } \\
\text { assisted supervision tools (CAST) and train personnel } \\
\text { accordingly. }\end{array}$ \\
\hline BCP 13. Other Risk & $\begin{array}{l}\text { The BRSA should issue specific sub-regulations (and } \\
\text { supporting guidelines) for legal risks and interest rate risks in } \\
\text { the banking book. }\end{array}$ \\
\hline BCP 15. Money Laundering & $\begin{array}{l}\text { The BRSA should ensure that its regular activities address } \\
\text { AML related risks as a major element of operational risk on a } \\
\text { systemic basis. } \\
\text { Bank reports on suspicious activities of material amounts } \\
\text { with regards to the safety, soundness or reputation of the } \\
\text { bank should always be submitted not only to the Financial } \\
\text { Crime Investigation Board (MASAK) but also to the BRSA. }\end{array}$ \\
\hline
\end{tabular}




\begin{tabular}{|c|c|}
\hline Reference Principle & Recommended Action \\
\hline $\begin{array}{l}\text { BCP 16. On-Site and Off-Site } \\
\text { Supervision }\end{array}$ & $\begin{array}{l}\text { The main inspection report should contain the findings of } \\
\text { other examinations of the same bank conducted during the } \\
\text { same supervisory cycle. This is necessary in order to present } \\
\text { a complete picture of a bank's soundness. } \\
\text { Furthermore, inspection reports should be more focused on } \\
\text { analyses and judgments. The reports should start with a short } \\
\text { "executive summary" (for example, no more than two pages) } \\
\text { outlining the main findings and draft recommendations. } \\
\text { Descriptions of general bank developments should be } \\
\text { transferred to appendices or separate reports. } \\
\text { The off-site analysis should be fully integrated with the on- } \\
\text { site process. } \\
\text { The enforcement of supervisory orders and recommendations } \\
\text { should also be fully integrated with the on-site process (see } \\
\text { also CP 22). }\end{array}$ \\
\hline BCP 18. Off-Site Supervision & $\begin{array}{l}\text { The BRSA should advance its recent work to enhance off- } \\
\text { site supervision. This would include expanding its } \\
\text { information base to collect, review and analyze } \\
\text { unconsolidated information on nonbank financial } \\
\text { subsidiaries and affiliates (including for banks' insurance } \\
\text { companies and intermediary companies in the capital } \\
\text { market). } \\
\text { The BRSA should also periodically collect and analyze } \\
\text { information on banks' parents (financial and nonfinancial) } \\
\text { and, when relevant, their affiliates. } \\
\text { The BRSA should begin planning for the collection and } \\
\text { analysis of additional information of, for instance, banks' } \\
\text { off-balance sheet operations as new markets develop, and } \\
\text { market-based indicators of financial soundness. }\end{array}$ \\
\hline $\begin{array}{l}\text { BCP } 19 . \text { Validation of Supervisory } \\
\text { Information }\end{array}$ & $\begin{array}{l}\text { The BRSA should fully implement ongoing efforts to } \\
\text { enhance IT inspections of banks and improve staff capacity } \\
\text { (number of staff and experience level) in this area. } \\
\text { Over the next one or two years, the BRSA should consider } \\
\text { adopting a work standard that requires a report to be issued } \\
\text { within } 60 \text { days of completion of an examination visit and } \\
\text { following the exit review at the end of on-site exercises. }\end{array}$ \\
\hline
\end{tabular}




\begin{tabular}{|c|c|}
\hline Reference Principle & Recommended Action \\
\hline BCP 20. Consolidated Supervision & $\begin{array}{l}\text { The BRSA should adopt a general practice to conduct an } \\
\text { "integrated" supervision inspection of the entire group, } \\
\text { assessing the potential effects on the bank emanating from } \\
\text { the other entities, financial as well as nonfinancial. } \\
\text { Other group companies, such as securities firms, mortgage } \\
\text { finance companies or insurance firms are regulated by other } \\
\text { supervisory agencies. In these cases the BRSA should always } \\
\text { proactively request to see inspection reports and other } \\
\text { relevant documents. The BRSA is encouraged to plan and } \\
\text { conduct simultaneous on-site inspections of such groups in } \\
\text { concert with other domestic regulators. } \\
\text { The BRSA should issue specific sub-regulations (and } \\
\text { supporting guidelines) requiring banks to adopt appropriate } \\
\text { risk management procedures to ensure the proper } \\
\text { identification of beneficial owners and cross-holdings of } \\
\text { other financial and non-financial companies. Such powers } \\
\text { would contribute also to compliance with large exposure and } \\
\text { connected lending principles. } \\
\text { The BRSA should also be prepared to conduct on-site visits } \\
\text { of banks' parent companies, be they financial or } \\
\text { nonfinancial, focusing on the relationship between the parent } \\
\text { and the bank, and when relevant the parent's affiliates. }\end{array}$ \\
\hline BCP 21. Accounting Standards & $\begin{array}{l}\text { The BRSA should proceed with its work plans for } 2007 \text { to } \\
\text { assess banks' implementation of the updated Turkish } \\
\text { accounting standards. }\end{array}$ \\
\hline
\end{tabular}




\begin{tabular}{|c|c|}
\hline Reference Principle & Recommended Action \\
\hline BCP 22. Remedial Measures & $\begin{array}{l}\text { The BRSA's enforcement process should not reassess nor } \\
\text { reprioritize the recommendations of the supervisors, unless it } \\
\text { finds material evidence of mistakes or if the BRSA Board } \\
\text { makes such a decision. } \\
\text { The inspection reports should clearly spell out the } \\
\text { recommendations, in priority order, and measures for taking } \\
\text { corrective actions. The BRSA review processes should be } \\
\text { accelerated both in the first internal review phase by the } \\
\text { supervision departments and in the enforcement phase. A } \\
\text { formal "exit meeting" involving onsite and offsite } \\
\text { supervisors as well as the Enforcement Department, at the } \\
\text { end of a supervisory cycle for an individual bank, could } \\
\text { assist in ensuring timely and comprehensive follow-up of } \\
\text { supervisory inspection findings. } \\
\text { Over the next one or two years, the authorities should adopt } \\
\text { guidelines which activate a progression of more severe } \\
\text { supervisory and enforcement measures, according to } \\
\text { objective and consistent criteria. This does not exclude } \\
\text { taking additional action if the situation warrants. }\end{array}$ \\
\hline $\begin{array}{l}\text { BCP 23. Globally Consolidated } \\
\text { Supervision }\end{array}$ & $\begin{array}{l}\text { The BRSA should include in the supervision of a bank group } \\
\text { its foreign affiliates of supervised entities on a fully } \\
\text { consolidated basis, including assessing the potential risks, } \\
\text { such as reputational and legal risks, on the parent bank } \\
\text { emanating from the foreign operations. }\end{array}$ \\
\hline BCP 24. Host Country Supervision & $\begin{array}{l}\text { The BRSA should develop informal or formal arrangements } \\
\text { with foreign supervisors (particularly with countries where } \\
\text { Turkish banks have material presence or with the home } \\
\text { countries of banks with a major presence in Turkey) to } \\
\text { ensure on-going cooperation and information sharing. }\end{array}$ \\
\hline
\end{tabular}

\section{Authorities' Response to the Assessment}

96. The BRSA would like to extend our thanks for the time and effort for preparing this report, as well as for their valuable comments and suggestions. Recognizing the significance of banking within the Turkish financial system, the BRSA puts great emphasis on effective supervision of the sector, along with harmonization and international convergence. This vision has been encouraging us to further improve our supervisory practices and regulatory framework and harmonize with international best practices and to enhance the institutional capacity of the BRSA. It is believed that significant 
progress has been made so far to become compliant to EU Directives and to the best practices such as Basel Core Principles.

97. The BRSA has been in the final stage of an organizational and regulatory transition process at the time of the assessment. The regulatory framework, supervisory practices and organization of the BRSA have been significantly changed in the last two years in order to reflect the past experiences and international best practices. The new BL has been approved, new sub-regulations have been issued afterwards and new Risk Focused Supervision has been initiated. On and off-site supervision is united, all supervision guidelines and tools are reviewed according to the new regulations. The BRSA Strategic plan, which determines the goals and targets of the Agency has been prepared and announced to the public. In that regard, the last couple of years is considered as a challenging period for the BRSA.

98. The BRSA appreciates the efforts for such a highly technical and thorough assessment. Now that it has changed its infrastructure, all legal framework, guidelines and tools BRSA will now focus on the recommended action plan in order to further progress its supervisory practices.

99. Specific comments for the main assessments of the FSAP team are presented below:

\section{Licensing and Structure (CPs 2-5)}

100. The regulation and supervision of factoring, leasing and financing companies are under the authorization of BRSA as of January 1, 2006. Although the regulation and supervision of other NBFIs such as insurance companies and intermediary companies are under the authorization of other authorities, BRSA's prior affirmative views are required by the related authorities in all cases. As the transaction will be prevented before its realization, the procedure should be considered as an "ex-ante" evaluation.

\section{Prudential regulations and requirements (CPs 6-15)}

101. BRSA is now in the process of preparing regulations in line with Basel II/CRD. The risks such as country and transfer risk, interest rate risk in the banking book will be dealt in these regulations., Internal processes, procedures and policies of banks regarding their credit portfolios and operations as well as their compliance with the appropriate regulations are assessed by the examiners during the on-site supervision process. In that context, supervision teams take into consideration the standards applied and the information required by the banks when lending to different segments of their consumers such as the corporate firms, SMEs and conglomerates, and make appropriate recommendations on these issues. And based on the findings in examination reports, banks are enforced by BRSA to correct deficiencies and defects in this area.

102. In addition to the criteria based on the period that the loan under consideration is overdue (which can be viewed as "objective criteria"), forward-looking criteria for 
loan classification are mentioned in the Regulation on Loan Loss Provisioning. These assessments include both the financial strength of the firms and the project evaluation if it is an investment credit. The risk assessment reports and safety and soundness reports include such kind of macro economical sector analysis, shareholder structure and other subjective criteria. In fact some examples of adverse classification regarding those types of criteria were also submitted.

103. According to the BL, a significant non qualified shareholder is subject to 25 percent limit. The sum of credit extended to all non qualified shareholders shall not exceed 50 percent of banks' own funds to the extent that they do not constitute a risk group. A significant person who has not any relation with bank subjects to 25 percent limit as well. There is no limit on the total amount of these kinds of credits, unless these significant persons constitute a risk group. BRSA believes this criterion makes "insiders" less favorable than related parties.

104. BRSA has already initiated to prepare market risk reports. The risk team has just finished examining 12 private banks and 3 state-owned banks and is currently preparing Market Risk Reports according to 2007 work plan. In addition to the market risk report of individual banks, the team has completed a report on the overall evaluation of these 12 private banks, including comparisons between these banks, and a report on the overall evaluation of state-owned banks, including comparisons between the state banks and the comparison of state banks with private banks. These examinations are conducted in light of new sub-regulations.

105. Furthermore, on site audit teams, equipped with appropriate feedback provided by the offsite personnel's monitoring activities, evaluate the market activities of banks taking into account the risk appetite of the bank as well as the sufficiency and effectiveness of internal policies and procedures and their compliance with relevant subregulations. Also, within the working instructions for 2007 that have been sent to supervision teams, it is required that supervisors should inspect the banks' implementation of all new sub-regulations including market risk

106. AML examination is a routine task that supervision groups have to examine during on-site inspections. This is also written in "Working Programs" and "Supervision Plans". Furthermore, onsite supervisors pay particular attention to compliance with "know your customer" rules during the supervision of branches, which constitute a part of regular bank examinations. In 2006, AML reports were prepared for 39 banks.

107. BRSA will further ensure that AML is taken into all "Supervision plans" and a separate section in "Safety and Soundness Reports" will be devoted to AML. The related supervision guidelines will be updated accordingly.

Methods of ongoing supervision (CPs 16-20)

108. The main inspection report does not necessarily contain the findings of other examinations. In case a special examination is required, a new report is prepared and it is 
equally powerful as the main inspection report and necessary enforcement actions are taken accordingly. Therefore it may not always be necessary to gather all the findings within one main report.

109. The offsite analysis has already been integrated with the on-site process in the context of the new organizational structure of Supervision Departments. New supervision teams have been formed where on-site and off-site supervisors are members of the same audit team(s). Reports produced by off-site supervisors provide an essential tool of feedback for on-site supervisors. Any non-compliance observed by the off-site supervisor is immediately reported to the examiner-in-charge who immediately adjusts the audit plan to make the necessary examination to prepare the compliance report. As a result, in addition to safety and soundness reports, there are also some compliance reports in the construction of which off-site supervisors do take part.

110. Supervision is one of the main functions of BRSA and BRSA gives very much importance to strengthen its supervision capabilities. Initiation of risk focused supervision, implementation of CAST (computer adapted supervision tool) and setting up new risk and macro reporting groups are major progressions for transition to "best practices."

\section{Remedial measures (CP 22)}

111. If there is a priority order in the recommendation part of an inspection report, the enforcement process does not reprioritize it. The enforcement process needs to prioritize the recommendations in inspection reports that is not in priority order, if there is any prompt need to take remedial actions.

112. Furthermore, BRSA is working on written guidelines for enforcement activities which will cover both the time frames for banks to take necessary actions and objective criteria that the enforcement actions are based on.

\section{International Organization Of Securities Commissions Principles of SECURITIES REGULATION}

\section{General}

113. The assessment of the IOSCO Objectives and Principles of Securities Regulation was conducted in April 2006 in the context of Turkey's participation in the FSAP. The assessment used for reference the February 2002 version of the Objectives and Principles of Securities Regulation together with the Methodology for Assessing Implementation of the IOSCO Objectives and Principles of Securities Regulation adopted in October 2003 by IOSCO.

114. The assessment focuses on the responsibilities, power and authority of the CMB as established in the Turkish Capital Market Law No. 2499 enacted in 1981 and Decree Law No. 91 incorporated into Law No. 2810 in 1983. 
115. The assessment was based on: (i) a detailed self-assessment by the CMB; (ii) documentation provided by the $\mathrm{CMB}$ including all relevant legislation, the annual report of the $\mathrm{CMB}$, and relevant statistical data; and (iii) meetings with the $\mathrm{CMB}$, market participants including the stock exchange, investment service providers, and industry associations.

\section{Capital market and structural overview}

116. The CMB is responsible for the regulation and supervision of the securities market and institutions as provided in the law, the determination of the operational principles of the capital markets, and protection of the rights and interests of investors. The CMB, established in 1982, regulates and supervises corporations offering their securities to the public; security market intermediaries; open-end mutual funds and closed-end companies; independent external auditing firms offering services to capital markets institutions; stock exchanges and secondary markets; precious metal and derivative exchanges (Istanbul Gold Exchange, TurkDex, the Futures and Options Exchange); and other related institutions operating on capital markets such as rating agencies, clearing and depository institutions (Takasbank). As the $\mathrm{CMB}$ is a part of the government, its decisions are subject to judicial review.

\section{Turkey's capital markets offer intermediary services, clear and settle}

transactions and disseminate data. The ISE, established as a public institution and the only stock exchange in the country, serves three markets based on the type of product, disclosure rules and governance: (i) the stock market, (ii) the bonds and bills market and (iii) the international market. At the time of the assessment, the ISE had 306 listed companies with a market capitalization of YTL 259 billion or approximately 41 percent of the 2005 GNP. Its traded value, which had dropped sharply after the 2001 crisis, exceeded the previous peak, reaching YTL 270 billion in 2005. The Turkish equity market ranks roughly in the middle of the emerging markets in terms of its size and activity level. Government securities dominate the bonds and bills market. Outstanding amounts of government bonds and Treasury bills stood at YTL 227 bullion (including non-marketable debt) and YTL 18 billion respectively as of end-December 2005.

118. Of the 141 intermediary institutions operating on the ISE at end-December 2005, 41 were banks and another 30 were subsidiaries of banks. The 30 bank-affiliated intermediaries had YTL 311 million in paid-in capital compared to YTL 251 million in the 70 other intermediaries.

\section{The domestic mutual fund market (mostly fixed income funds but some equity} funds) consisted of 275 funds with aggregate assets of about YTL 29 billion at endDecember 2005. Another 53 foreign-incorporated mutual funds also operated in the country. Mutual funds in Turkey are open-end funds. The assets of pension funds and investment trusts were 0.5 and 0.2 percent of market capitalization respectively at end-December 2005 . Investment trusts are closed-end investment companies investing in capital market instruments, gold and precious metals. 
120. Turkey follows a policy that allows foreign institutional and individual investments in securities listed on the ISE. Turkish stock and bond markets are open to foreign investors without restrictions on the repatriation of capital and profits. The taxation method and tax base may differ for various categories of foreigners.

\section{General preconditions for effective securities regulation}

121. In particular, Turkish securities regulations and practices are undergoing substantial change. A draft amendment to the Capital Markets Law is expected to be presented to the National Assembly in 2008 in order to include the results of a twinning project with the German financial regulator on harmonizing regulations with the EU "acquis" pertaining to capital markets. The acquis outlines a number of sound standards for capital market supervision, corporate governance and transparency, which if adopted, would bring Turkey's capital market and financial supervision into closer alignment with the IOSCO principles than it was at the time of the assessment.

122. In 2005, the CMB approved an Action Plan based on the results of a self assessment. In general, this assessment confirms the findings of the self-assessment. Implementation of the Action Plan is proceeding; however, some of the areas identified in this assessment require further attention, as discussed below.

\section{Main findings}

123. The overall quality of the supervisory framework for securities markets in Turkey is deemed satisfactory, but several aspects of regulation and enforcement require further improvement.

124. Principles relating to the Regulator (Principles 1 to 5). While the responsibilities of the CMB are clear and objectively stated, its duties overlap in some areas with other financial regulators: the Banking Regulation and Supervision Agency, the Undersecretariat of the Treasury, the Ministry of Finance and the related Minister of State, and recently the Turkish Accounting Standards Board and the Individual Pension Advisory Board. However, there are no operative procedures in place for regular cooperation, consultation and exchange of information among responsible authorities. The CMB, in its self assessment, does not describe existing arrangements as effective.

125. The CMB has adequate funding given the level of activity in the markets from transaction fees and specified contributions from authorized exchanges. When markets are inactive, the potential shortfall must be covered by a budgetary transfer from the Ministry of Finance, which could have a bearing on its independence. However, the draft amendments to the Law provide for additional revenues from increasing registration fees on issuers and introducing new fees on various types of market participants.

126. Principles of Self-Regulation (Principles 6 to 7). Turkey has four Self-Regulating Organizations (SROs), notably, the ISE, all of which have clear responsibilities for regulating and supervising their members and promoting their markets. The CMB cooperates in 
conducting market surveillance with the SROs and has the responsibility of SRO oversight. However, the legal relationships between the CMB and ISE, a public autonomous agency, could be clarified. The CMB does not appear to have in place systematic programs of inspection of the operations of the SROs. Some of the SROs are established as public legal entities and an effective program of oversight could be used to establish recognition criteria and performance standards for them.

\section{Principles for Enforcement of Securities Regulation (Principles 8 to 10).}

Investigative and enforcement power to collect information and conduct inspections is adequately granted to the CMB. However, there is a need for a well articulated strategy that would ensure consistency and efficiency in supervision and enforcement.

128. Principles for Cooperation in Regulation (Principles 11 to 13). The regulator has the authority to share information with other domestic regulators, but it is not clear how much information sharing occurs in practice. For example, the absence of a definition in the law of financial conglomerates could confound information gathering. There are no systematic procedures in place for cooperation among responsible authorities. However, no restrictions are imposed on information sharing with cross-border counterparts.

129. Principles for Issuers (Principles 14 to 16). Various measures have been taken in recent years to harmonize the treatment of listed banks and other publicly traded companies in terms of drawing up of accounts and public disclosure of material information. The recent adoption of IFRS and international auditing standards poses a supervisory challenge of ensuring compliance, while there is a continuing need to protect effectively the interests of minority shareholders, especially in mergers and takeovers, and in the context of the large complex conglomerates. Better disclosure of information by listed firms and issuers would be desirable.

130. Principles for Collective Investment Schemes (Principles 17 to 20). The establishment of a Collective Investment Scheme (CIS) requires a license from the CMB, which regulates CIS, and must approve the different schemes and their marketing across jurisdictions. On-site inspections of CISs should be undertaken on a regular basis, while more detailed tasks should be specified for their internal auditors. The rules on the segregation and safe custody of assets that are applied on pension mutual funds should also be imposed on all types of CISs. The use of consistent valuation models of illiquid assets across all types of CIS should be monitored by the CMB and improved. It would be desirable to introduce a more effective mechanism for dealing with investor complaints.

131. Principles for Market Intermediaries (Principles 21 to 24). Regulation in Turkey provides minimum entry standards for market intermediaries, including adequate capital to cover market, credit and liquidity risks. However, there are no provisions regarding operational, legal and reputational risks. Further, market intermediaries are not required to comply with standards for internal organization and operational conduct that would protect clients' interests and ensure proper risk management. Measures for dealing with firm failure 
are contained in the law, but clear guidelines should be issued to stipulate the ladder of intervention measures that would be implemented in any given case.

132. Principles for Secondary Markets (Principles 25 to 30). Exchange operating companies require approval by the $\mathrm{CMB}$; however, it delegates certain regulatory powers to the ISE and Takasbank. There are no clear performance criteria for the ISE, which operates as a public legal entity. The current oversight arrangements restrict the CMB's powers and could give rise to conflicts of interest. The draft amendments to the Law provide that all securities exchanges shall be established as private law entities. The existence of exchanges as public legal entities will be possible only in exceptional cases. The conditions for the establishment and operation of exchanges should be clearly specified in the amendments and the exchanges subject to full inspection by the CMB. The status of the ISE should be clarified and arrangements made so that it can operate effectively in what is an increasingly competitive international environment for exchanges.

133. Trade transparency and detection of market abuses are facilitated by the electronic trading system and market surveillance undertaken by the CMB and the exchanges. However, large shareholders are not included in the definition of insiders, which inhibits the effective monitoring of insider trading and may reduce the attractiveness of the market for some investors. The real-time surveillance project, which is developed jointly by the CMB and ISE, is expected to be operational in the near future. It will later on include an insider trading module. The draft amendments to the Law will include large shareholders in the definition of insiders, which should increase confidence in the operation of the market.

134. Systems for clearing and settlement of securities are assessed separately under the CPSS/IOSCO assessment also conducted in the context of the FSAP.

\section{Recommended actions}

Table 8. Recommended Plan of Actions to Improve Implementation of the IOSCO Objectives and Principles for Securities Regulation

\begin{tabular}{|l|l|}
\hline Reference Principles & Recommended Action \\
\hline $\begin{array}{l}\text { Principles Relating to the } \\
\text { Regulator (1 to 5) }\end{array}$ & $\begin{array}{l}\text { Various measures should be taken to reinforce the independence of } \\
\text { the regulator, including inter alia, a clear stipulation of the } \\
\text { circumstances under which the Related Minister may request } \\
\text { information from the CMB, an increase in its sources of funding, } \\
\text { provision of legal immunity to regulators for actions taken in good } \\
\text { faith, and effective cooperation with other regulators. }\end{array}$ \\
\hline $\begin{array}{l}\text { Principles of Self-Regulation } \\
\text { (6 and 7) }\end{array}$ & $\begin{array}{l}\text { The authorities should promote a clearer distinction in the } \\
\text { respective roles of the CMB and the ISE, which is an autonomous } \\
\text { public agency. The former should have regulatory and supervisory } \\
\text { powers over the ISE, while the latter should focus on promoting the } \\
\text { efficiency and development of the stock exchange. Institutional } \\
\text { changes may be necessary to enhance the transparency of both the }\end{array}$ \\
\hline
\end{tabular}




\begin{tabular}{|c|c|}
\hline Reference Principles & Recommended Action \\
\hline & $\begin{array}{l}\text { CMB and ISE in the exercise of their respective functions and to } \\
\text { reduce the risk of conflict of interests. An effective program of } \\
\text { periodic inspections of the operations of the SROs should be } \\
\text { undertaken. }\end{array}$ \\
\hline $\begin{array}{l}\text { Principles for Enforcement of } \\
\text { Securities Regulation (8 to 10) }\end{array}$ & $\begin{array}{l}\text { The CMB should establish a practice of preparing a forward and } \\
\text { consolidated strategy for supervision in order to promote } \\
\text { consistency and efficiency. The authorities are also recommended } \\
\text { to enhance the effectiveness of court actions by promoting the } \\
\text { knowledge of financial markets within the courts. }\end{array}$ \\
\hline $\begin{array}{l}\text { Principles for Cooperation in } \\
\text { Regulation (11 to } 13)\end{array}$ & $\begin{array}{l}\text { Systematic procedures for regular cooperation and sharing of } \\
\text { information among responsible authorities should be established. } \\
\text { Financial conglomerates should be better defined in the applicable } \\
\text { laws. }\end{array}$ \\
\hline $\begin{array}{l}\text { Principles for Collective } \\
\text { Investment Schemes (17 to 20) }\end{array}$ & $\begin{array}{l}\text { On-site inspections of CISs should be undertaken on a regular basis } \\
\text { All CIS prospectuses should provide an explanation of the risks } \\
\text { involved in reaching investment objectives; at present only pension } \\
\text { funds are required to include this information in their disclosure } \\
\text { documents. Common valuation principles for illiquid assets should } \\
\text { be adopted by all CISs and improved. }\end{array}$ \\
\hline $\begin{array}{l}\text { Principles for Market } \\
\text { Intermediaries (21 to 24) }\end{array}$ & $\begin{array}{l}\text { The relevant provisions of the Action Plan should be implemented. } \\
\text { These address the capital adequacy requirements of market } \\
\text { intermediaries, the provision of clear explanations of investment } \\
\text { risks to their clients, and the stipulation of a clear ladder of } \\
\text { intervention measures when firms face financial difficulties. } \\
\text { Intermediaries should be required to provide an effective } \\
\text { mechanism for resolving investor complaints. }\end{array}$ \\
\hline $\begin{array}{l}\text { Principles for Secondary } \\
\text { Markets ( } 25 \text { to } 30)\end{array}$ & $\begin{array}{l}\text { The relevant provisions of the Amendments to the Law and the } \\
\text { Action Plan should be implemented. These cover the establishment } \\
\text { of all securities exchanges as private law entities and the inclusion } \\
\text { of large shareholders in the definition of insiders. In particular, the } \\
\text { status of the ISE should be clarified in such a way as to allow it to } \\
\text { remain internationally competitive in terms of costs and services. } \\
\text { The joint real-time surveillance project should be completed and } \\
\text { placed in operation, while the insider trading module should be } \\
\text { developed without undue delay. }\end{array}$ \\
\hline
\end{tabular}

\section{Authorities' response.}

135. Regarding the recommendation that require clarifying the legal relationships between the CMB and the ISE, a public autonomous agency, we believe that the supervisory relationship between the CMB and the ISE is clear. Although ISE is not an SRO with four corners, CMB is under the obligation to supervise all of its operations. 
136. It is indicated that CMB does not appear to have in place systematic programs of inspection of the operations of the SROs. However; CMB annually conducts operational and financial inspections over the SROs including the inspections of IT Systems. Since business processes are becoming more dependent on IT systems, the IT systems of Turkish Capital Market Institutions such as Istanbul Stock Exchange, ISE Settlement and Custody Bank Inc., etc. are periodically audited by the IT Department of CMB within the concept of materiality and its relationship with audit risk. During this IT audit, the IT Department of $\mathrm{CMB}$ focuses on the organization's IT system, including the areas like information security, information systems strategy and planning, information systems operations, network infrastructure, database, business continuity planning, relationships with outsourced service providers etc., utilizing internationally accepted frameworks and standards such as COBIT, ISO 27001, COSO etc. The overall aim of the audit process is to provide IT Governance for SROs mainly by maximizing security, availability, integrity, performance and effectiveness of the organizations' IT systems, improving IT processes and awareness about information security issues.

137. The FSAP Team has indicated that more detailed tasks should be specified for the internal auditors of mutual funds. On September 22, 2006 an amendment has been made in the communiqué related to mutual funds, stating the rules and procedures of the internal control of the funds and the tasks of the internal auditor.

138. Mutual fund prospectuses cover risk and investment objectives but they are not as detailed as pension funds. As $\mathrm{CMB}$ plans to review mutual fund communiqué, will review all of these kinds of issues with new communiqués. With these revisions it is also planned to introduce hedge funds, capital guaranteed funds, funds of funds, etc. The drafts of the communiqués have been prepared. After introducing these new instruments, prospectus standards will be reviewed in such a way that will involve this issue. As these new instruments will have different risk and investment objectives, they will have different disclosure principles.

139. The FSAP Team has indicated that large shareholders are not included in the definition of insiders, which inhibits the effective monitoring of insider trading and may reduce the attractiveness of the market for some investors. Even though large shareholders are not explicitly defined as insider at Article 47 of the Law, currently CMB has the ability to investigate their transactions against this article since the scope of the article is so broad. Additionally, According to the Article 5/h-1 of the Communiqué on the Disclosure Principles of Material Events, purchase or sale of the stocks of the corporation by shareholders who directly or indirectly own 5 percent or more of the capital or voting rights, and the persons acting in concert is defined as a material event. Therefore such transactions should be disclosed through ISE daily bulletin. Furthermore, large shareholders are still in the focus of insider investigations, since they are always potential insider. In practice, while we are investigating an insider cases, large share holders always exist in our scope.

140. The FSAP Team has recommended to ensure prompt filing of material changes in ownership or operations of listed enterprises and information about cross holdings. 
CMB Communiqué numbered Serial:VIII, No:39 Principles Regarding Public Disclosure of Material Events ensure prompt filing of material changes in ownership or operations of listed enterprises, however disclosure requirement relating to cross holdings is not at sufficient level.

141. Regarding the FSAP recommendation as to the introduction of valuation model for the treatment of illiquid infrequently traded securities, we would like to mention that, the valuation principles for the assets in the mutual funds are written in detail in mutual fund communiqué. The provision in the Article 45 of the communiqué says that "although traded on stock exchange, stocks not subject to sale and purchase at the date of valuation shall be valued at exchange price at the last transaction date whereas, debt securities, reverse repos and repos shall be valued at internal rate of return of the last transaction date (discount rate equalizing daily cash inflows to cash outflows)." So if there are illiquid assets, this article clearly states valuation method.

142. For the aim of customer protection, a new obligation has come into force with an amendment made to the Article 13 of Communiqué Serial: V, No: 46. According to this new provision, "Intermediary institutions can not conclude a written agreement or provide services, unless the customers have signed the "capital market activities risk notice form" explaining the risks of the capital market, and the contents of the form will be determined by the Board.

143. The FSAP Team has indicated that there is a need for a well articulated strategy that would ensure consistency and efficiency in supervision and enforcement. In fact, $\mathrm{CMB}$ plans and organizes working plans. CMB gets many complaints from all market participants, notification from other institutions. CMB prepares its plans accordingly. For example, in 1997-2000 period there were many unregistered public offerings, so CMB supervised and enforce this issue intensively. In 2000-2003 period there were many market manipulation cases and $\mathrm{CMB}$ enforced and supervised this issue. In addition, since the strategy of CMB was to prevent market manipulation, we introduced the requirement of "trading with customer account number" and started to develop real-time surveillances system. Besides, we have also enhanced the cooperation between CMB and ISE on the manipulation cases and shortened the investigation period substantially, and we have started to take additional precautions about the manipulative stock in ISE such as limiting margin trading, short selling etc. Our scope was on investment funds in 2005 and is on insider dealing in 2006. All these focus areas were part of our enforcement strategy. 


\section{Summary ASSESSMENT REPORT ON THE CPSS CORE PrinCIPLES FOR SYSTEMICALly IMPORTANT PAYMENT SYSTEMS AND THE CPSS-IOSCO RECOMMENDATIONS FOR SECURITIES SETTLEMENT SySTEMS ${ }^{20}$}

\section{General}

144. This document summarizes the results of an assessment of systemically important payment systems in The Republic of Turkey based on the CPSS Core Principles for Systemically Important Payment Systems (CPSIPS) and the CPSSIOSCO Recommendations for Securities Settlement Systems. The assessment was conducted in the context of the FSAP mission to Turkey in April 2006. The authorities were very helpful in all aspects of the assessment. The main counterparts were the CBRT, the CMB, the ISE, Takasbank (ISE Settlement and Custody Bank), and the CRA (Central Registry Agency). The assessment has been modified to take account of the comments received from the $\mathrm{CBRT}$ and $\mathrm{CMB}$ following their analysis of the initial draft.

145. In general the payment and settlement systems are technically efficient and reliable, and are supported by an appropriate regulatory framework and effective oversight. The CBRT and the CMB have demonstrated a strong interest in promoting safety and improving efficiency in settlement systems as part of their responsibilities to promote financial stability. Also, they have been influential in improving public understanding of the clearance and settlement arrangements, and continue to encourage and support additional initiatives to assure safety, reliability and efficiency.

\section{Payment settlement systems infrastructure}

\section{Overview}

146. The FSAP assessment focused on those elements of the National Payments System that were considered of systemic importance, namely:

a.) TIC-RTGS (Turkish Interbank Clearing - Electronic Funds Transfer System) which is the real-time gross settlement system of Turkey. A noteworthy feature of TIC-RTGS is that it was designed to process both large value and low value transactions. A second generation TIC-RTGS (based on the well established and widely used CAS System developed by LOGICA CMG) system was installed in 2000 .

b.) ICH, a standard multilateral net settlement system for checks that supports the settlement of check clearing services throughout Turkey. ${ }^{21}$

\footnotetext{
${ }^{20}$ The assessor was Robert H. Keppler, Senior Advisor, Financial Sector Operations and Policy Department at the World Bank.
} 
147. The Post Office provides postal check account facilities to any firm or individual. Postal check accounts are used mostly by public institutions for collecting various types of tax and by companies for receiving payment installments. Thus, the postal check system is a well-used retail system, but the transaction value is small relative to that of other systems, so this system is not considered to be of systemic importance. Credit card operations are cleared through a system operated by a not-for-profit organization; "Interbank Card Center (BKM)." Final settlement of the net debits and credits resulting from the BKM clearing system takes place over accounts maintained at the Istanbul branch of CBRT via the TIC-RTGS system. The BKM card based system is an important component of the payments system architecture and is of high operational importance but is not of systemic importance.

148. The main payment instruments used in Turkey are credit transfers, credit and debit cards, checks and postal remittances. In 2005, the TIC-RTGS transaction volume was $\quad 77.7$ million, with a corresponding value of YTL 7,844.2 billion. This was much larger than the check volume and value of 23.5 million with a value of YTL 156.1 billion.

\section{Main findings regarding systemically important payments systems}

- Legal foundation (CP I). A sound legal framework for the payment systems is provided by the CBRT Law, the TIC-RTGS Operational Rule Book, relevant CBRT circulars, and other related laws (Banking, Insolvency, Commercial, etc.). All materials are readily available to the public. However, the definition of payment finality is not explicitly defined in the CBRT Law, which could conceivably lead to legal challenges.

The "Arrangement of Payments by Check and Protection of Check Bearers Act" (Law No. 3167) governs all aspects of payment by check and provides the framework for issue, acceptance and payment of checks, and the establishment and functioning of interbank clearing houses. A new electronic clearing regulation is being prepared to cover planned innovations and will include information truncation capabilities. These new capabilities are being introduced in response to participants' requests and it is thus likely that additional processing efficiencies will be achieved within a sound legal framework. Final settlement of ICH balances takes place through the TIC-RTGS system.

- Understanding and management of risks (CPs II-III). The readily available system information is sufficient for use by participants to fully understand the financial, operational, and reputational risks that they will be exposed to through participation in TIC-RTGS. The liquidity related features and functions are sufficient to allow a participant to fully understand and mitigate its exposure to liquidity risk in an acceptable manner. The arrangements designed to provide intraday liquidity (mobilization of required reserves and collateralized intraday credits) and to facilitate the smooth

\footnotetext{
${ }^{21}$ A new, fully automated system with enhanced capabilities of both imaging and truncation techniques was introduced in September 2006.
} 
execution of payments (queuing facilities with priorities and gridlock resolution mechanisms, pricing incentives, time scheduling of payments) are in line with best international practice.

- The ICH system allows a participant to proactively manage liquidity risks and credit risks, provides an intraday liquidity facility, and as a last resort provides for unwinding. Also, the penalty - expulsion from the system - is viewed as a severe incentive to assure settlement. Nevertheless, the process of unwinding, although technically feasible, is not a preferred solution as it does not guarantee settlement of the new positions. Settlement risk attaching to such situations could be mitigated through a suitable "failure to settle/ loss sharing" arrangement and the transfer of all large value check payments into RTGS payments.

- Settlement (CPs IV-VI). The TIC-RTGS involves no netting. Transaction flow and processing rules are such that — providing that funds are available — settlement either takes place immediately in real time, following the release of reserved or earmarked funds, or in a worst case scenario during a gridlock busting operation. Settlement is assured no later than the end of the operational day so no unsettled transactions remain at close of business. Settlement is in CBRT's funds. Even when the CBRT provides intraday credit to assure settlement, there is no credit risk to CBRT as the credit is fully collateralized.

- Security and operational reliability, and contingency arrangements (CP VII). Experience over a relatively long period of operation confirms the robustness of the overall system from a reliability and security perspective. The logical and physical reliability, contingency and security features embedded in the TIC-RTGS are of a high standard.

The ICH system is robust and operationally reliable; no problems have occurred during the past three years. Although the system has performed well, a new system was introduced in September 2006 to provide an upgrade.

- Efficiency and practicality of the system (CP VIII). TIC-RTGS is a well accepted and well used system that satisfies the operational needs of the financial and broader segments of the economy in ways that are viewed as being operationally and cost effective. The current ICH system satisfies market needs, but opportunities exist-and are being pursued - to exploit technology based improvements to reduce the settlement cycle.

- Criteria for participation (CP IX). Participation criteria are fair, objective, and publicly available.

- Governance of the payment system (CP X). TIC-RTGS is owned and operated by CBRT. A number of practical formal and informal arrangements are in place and are used 
actively to ensure that all aspects of the TIC-RTGS system continue to satisfy user needs and comply with best practices. The Executive Board of the $\mathrm{ICH}$, with representatives of the CBRT and 11 commercial banks, is responsible for all aspects of the ICH governance; the primary objective of the ICH Board is to assure the responsiveness of the ICH system to the needs of the entire membership.

\section{Recommended actions regarding systemically important payment systems}

149. Below are some actions that the CBRT could take to improve the already high quality of Turkey's systemically important payments systems.

\section{TIC-RTGS}

\begin{tabular}{|c|l|}
\hline TIC-RTGS Reference principle & \multicolumn{1}{|c|}{ Recommended action } \\
\hline Legal foundation (TIC-RTGS CP I) & $\begin{array}{l}\text { A sound legal basis for the national payment system must } \\
\text { satisfy five basic requirements: (a) the power to establish } \\
\text { payment systems; (b) the power to make regulations; (c) the } \\
\text { power to enter into contracts; (d) the power to arbitrate and } \\
\text { bind parties, and e) the existence of a clear and unambiguous } \\
\text { finality of payment definition embedded in law. The CBRT } \\
\text { already has powers (a) through (d). Also, an adequate } \\
\text { definition of the immediate finality of payments is embedded } \\
\text { in the TIC-RTGS Rule Book. } \\
\text { Nonetheless, the definition of payment finality is not explicitly } \\
\text { defined in the CBRT Act, Law No: 1211 and thus a challenge } \\
\text { to the finality of payments might be attempted, though it is } \\
\text { unlikely that such a challenge would prevail. The possibility } \\
\text { can be eliminated completely by adding a clause to the CBRT } \\
\text { Act such as that set out below: } \\
\text { A payment or transfer made through the TIC-RTGS payment } \\
\text { system established under Article 4-I-f is final and irrevocable. } \\
\text { Notwithstanding anything to the contrary in any other law, } \\
\text { (including the law relating to insolvency and priority of } \\
\text { creditors) no payment or transfer made through the TIC-RTGS } \\
\text { payment system shall be required to be reversed, repaid or set } \\
\text { aside and no court shall order such payment or transfer to be } \\
\text { rectified or stayed. } \\
\text { Nothing in the paragraph above shall affect any other legal } \\
\text { right or remedy available to a person who has suffered any loss } \\
\text { or damage by a payment, transfer or settlement effected } \\
\text { through the TIC-RTGS system. }\end{array}$ \\
\hline
\end{tabular}




\section{ICH}

\begin{tabular}{|l|l|}
\hline \multicolumn{1}{|c|}{ ICH Reference principle } & \multicolumn{1}{c|}{ Recommended action } \\
\hline Legal foundation (ICH CP I) & $\begin{array}{l}\text { The recommended action relating to the TIC-RTGS system } \\
\text { will also remove any legal uncertainty relating to settlement in } \\
\text { the ICH system as final settlement of the net positions are } \\
\text { affected through the TIC-RTGS system. }\end{array}$ \\
\hline $\begin{array}{l}\text { Failure to Settle Risks (ICH - } \\
\text { CP III, CP IV, and CP V) }\end{array}$ & $\begin{array}{l}\text { The ICH Executive Board is planning to convert the ICH } \\
\text { system into a same day settlement system. It is recommended } \\
\text { that an explicit set of "failure to settle" mechanisms are put in } \\
\text { place both to remove any dependency on an unwinding } \\
\text { procedure and to remove any uncertainty. This might be based } \\
\text { on any of the following: a suitable form of loss sharing } \\
\text { arrangement, a pre-funding of net debit position arrangement, } \\
\text { or a suitable guarantee fund mechanism. Additionally, the } \\
\text { likelihood of a settlement failure could be further reduced } \\
\text { through the conversion of large value check payments into } \\
\text { RTGS payments. }\end{array}$ \\
\hline
\end{tabular}

\section{Central Bank's Responsibilities}

\begin{tabular}{|c|c|}
\hline $\begin{array}{l}\text { CB Responsibilities Reference } \\
\text { principle }\end{array}$ & Recommended action \\
\hline Responsibility A & $\begin{array}{l}\text { Although CBRT has an explicit responsibility to assure public } \\
\text { confidence, there is no mention of a specific consumer } \\
\text { protection role. It is recommended that a consumer protection } \\
\text { policy be developed confirming the role to be filled by the } \\
\text { CBRT in monitoring the operation of the national payments } \\
\text { systems from a consumer fairness perspective. }\end{array}$ \\
\hline Responsibility B & $\begin{array}{l}\text { Prior to implementing the updated ICH system, the CBRT } \\
\text { should assure that all relevant CPs are satisfied. }\end{array}$ \\
\hline Responsibility C & $\begin{array}{l}\text { Although the CBRT has the authority to oversee all payment } \\
\text { systems in Turkey, it is evident that little oversight activities } \\
\text { have actually been implemented. } \\
\text { CBRT should evaluate the need to establish a structural } \\
\text { separation between its activities as service provider and its } \\
\text { activities as payments system overseer. }\end{array}$ \\
\hline
\end{tabular}




\section{Securities settlement system}

\section{Overview}

150. The elements of securities settlement infrastructure, on which the assessment focused, comprises:

c.) Takasbank/CRA (Electronic Security transfer and Settlement System) that transfers and settles transactions related to the organized markets operated by The ISE in accordance with Model 3 Delivery versus Payment (DvP) principles. There is a separate but linked (to the ISE Settlement) DvP settlement system operated by Takasbank, which uses Model 1 RTGS DvP in transactions between indirect participants, i.e., broker to custodian transactions. The CRA is the central depository for equities, mutual fund certificates, and corporate bonds that are dematerialized. Takasbank has a 65 percent shareholding in the CRA. For FSAP purposes, the Takasbank system and the related CRA system is viewed as a single integrated system.

d.) TIC-ESTS, the Turkish Interbank Clearing the Electronic Security Transfer and Settlement System) that transfers and settles Turkish government securities transactions in accordance with "Model 1 Delivery versus Payment" (DvP) principles. It is also the Central Depository for government securities.

151. Equities issued by some 315 companies are traded on the ISE. The average daily number of contracts agreed amongst the 98 members is in the order of 173,000 with a value in the order of US\$1.2 billion. In the secondary market for government securities, market turnover exceeded YTL 800 billion in 2005, implying an annual turnover ratio of about 4 times relative to the stock of marketable debt outstanding.

\section{Takasbank is the clearing and settlement institution for the ISE and the Turkish} Derivatives Exchange, and acts as custodian for pension funds and the national numbering agency. The CRA is authorized to dematerialize and register capital market instruments and associated rights. All transfers processed in the Takasbank and CRA systems are realized in book entry form. 


\section{Main findings}

- Legal risk (recommendation 1). Laws, regulations, rules and procedures and contractual provisions governing the operation of the Taksbank/CRA system and TIC-EST are public and accessible to system participants. The legal framework demonstrates a clear legal basis and a high degree of legal assurance for each aspect of the settlement process. The rules and contracts are enforceable in the event of insolvency of a system participant, subject only to the payments finality issue mentioned under TIC-RTGS CP I. TIC-RTGSESTS settles securities transfers on a model 1 DvP basis; thus no netting issues arise.

- Pre-settlement risk (recommendations 2-5). Confirmation of trades in government securities is available on a timely basis. The integration of TIC-ESTS and TIC-RTGS ensures prompt settlement, there is no netting. Securities lending is supported.

For equities, direct dealer participants receive confirmation on $\mathrm{T}+0$. Additionally, indirect participants who are the institutional investors such as investment funds, mutual funds also receive trade reports from their office terminals on $\mathrm{T}+0$. (The system is being upgraded: Takasbank has started up a project called "SWIFT Integration Process to RTGS Model 1 DvP settlement" in order to establish a system whereby the custodian banks and brokerage houses can receive the confirmation messages from each other on $\mathrm{T}+1$.) Final settlement is on a $\mathrm{T}+2$ basis. Securities lending and borrowing is fully supported, and is fully collateralized marked to market daily, and supported by margin calls.

- Settlement risk (recommendations 6-10). Almost all government securities are dematerialized. Government securities are settled on a gross basis. Final settlement occurs intraday or at the latest by the end of day. As the TIC-RTGS- ESTS operates as a RTGS system using central bank funds for settlement, there is no risk of failure on either side of the transaction. Overdraft and debit balances in securities are not allowed.

$\mathrm{CMB}$ regulations require that all Equity Certificates and Mutual Fund Certificates be dematerialized. Comprehensive plans are being implemented to fully dematerialize all securities traded in the organized markets operated by the ISE. DvP is achieved in a suitable manner in the Takasbank/CRA integrated system. Settlement is finalized with same day securities and cash (using central bank funds). Appropriate monitoring controls are in place to assure settlement. However, the potential legal vulnerability associated with the insolvency of a participant in the TIC-RTGS system could also impact the finality of settlement in the Takasbank/CRA system.

- Operational risk (recommendation 11). Contingency plans and business continuity plans are well designed, documented and practiced.

- Custody risk (recommendation 12). The TIC-ESTS permits and encourages segregation of dealer direct participant accounts from the customer accounts, which protects customer securities All entities holding securities in custody are supervised or regulated. CRA 
participants are required to segregate assets held for their own benefit and assets they hold for their client. Custodians are subject to audit by CMB and ISE.

- Other issues (recommendations 13-19). Since TIC-ESTS is embedded in an integrated TIC-RTGS-ESTS, governance arrangements and access rules are similar to those relating to TIC-RTGS. The TIC-ESTS fulfils participant, public, government and central bank demands on a security settlement system in a cost efficient and business efficient manner. The participant contract and the operational rules are detailed and give sufficient information for the participants to evaluate the risk and costs associated with using TICESTS. The tools to implement the CBRT oversight function in regard to all payment systems are in place. However, no formal oversight plan exists, and the oversight function is not organizationally separate from operational functions. The TIC-RTGSESTS system is not designed to support cross border security transfers;

For equities, Takasbank is owned by the ISE and 90 ISE members. CRA's Board of Directors is composed of one representative from CMB who also acts as Chairperson, two representatives from Takasbank, two representatives from ISE, one representative from The Association of Capital Market Intermediary Institutions of Turkey, and the General Manager of CRA. For both institutions, objectives and major decisions are disclosed. Access criteria are fully disclosed and are not restrictive. Takasbank and CRA systems provide the services that are required by participants in a technically efficient manner. However, it has not been possible to assess formally the degree to which users are satisfied with all critical aspects of the systems. There are provisions for international connectivity, but the system is essentially nationally-based. However, cross border transactions ISO 15022 standard (via SWIFT messages) and other international coding standards (ISIN, CFI, MIC etc) are used. In 2007 the CRA published its completed CPSS/IOSCO Disclosure Framework.

Recommended actions regarding securities settlement systems

153. Below are some actions that would improve observance of CPSS-IOSCO Recommendations for Securities Settlement Systems.

TIC-ESTS

\begin{tabular}{|c|l|}
\hline \multicolumn{1}{|c|}{ Reference Recommendation } & \multicolumn{1}{|c|}{ Recommended action } \\
\hline Oversight (Rec. 18) & $\begin{array}{l}\text { Active oversight function should be established and become } \\
\text { operational with a formal work program underpinning its } \\
\text { activities. }\end{array}$ \\
\hline
\end{tabular}


Takasbank/CRA

\begin{tabular}{|l|l|}
\hline \multicolumn{1}{|c|}{ Reference Recommendation } & \multicolumn{1}{c|}{ Recommended action } \\
\hline Trade confirmation (Rec. 2) & $\begin{array}{l}\text { The planned modifications that facilitate T+1 confirmation for } \\
\text { indirect participants should be implemented. }\end{array}$ \\
\hline Cost and business efficiency (Rec. 15) & $\begin{array}{l}\text { An independent assessment and confirmation of user } \\
\text { confidence in the system from a service fee perspective should } \\
\text { be undertaken. }\end{array}$ \\
\hline International connectivity (Rec. 16) & $\begin{array}{l}\text { Discussions should take place with participants to determine } \\
\text { the degree to which market evolution will require international } \\
\text { connectivity. A suitable action plan should be developed and } \\
\text { implemented as soon as a compelling business need has been } \\
\text { identified and agreed. }\end{array}$ \\
\hline $\begin{array}{l}\text { Opportunity to understand all risks } \\
\text { associated with membership (Rec. 17) }\end{array}$ & $\begin{array}{l}\text { The CPSS/IOSCO Disclosure Framework should be published } \\
\text { by CRA. }\end{array}$ \\
\hline $\begin{array}{l}\text { Other Issues (Rec. 4). Benefits of } \\
\text { introducing a CCP mechanism }\end{array}$ & $\begin{array}{l}\text { Takasbank should initiate a new study to determine whether } \\
\text { the cost versus benefit relationship has changed since the last } \\
\text { study in 2001. }\end{array}$ \\
\hline
\end{tabular}

\section{Authorities' response}

154. In general, CBRT agrees with the findings and assessments of the FSAP team and we appreciate the recommendations for further improvements of the payment systems.

- The CBRT is well aware of the importance of the payment system's oversight. Extension of the CBRT's oversight role in regard to all payment systems has already taken place in the CBRT's medium term strategic plans.

- Although consumer protection concept is not directly referred to the payments system legislation, consumer claims can be based on the Law on Consumer Protection (Law No. 4077), the BL (Law No. 5411) and the Law of Obligations (Law No. 818). However, a separate payment system law may be considered for further improvement in the efficiency of payment system.

155. Regarding the securities settlement system, all outstanding issues are on the agenda of the CMB and the other related institution, and encouraging steps will be made in the following years.

- Regarding the recommendation 2 on trade confirmation, indirect participants who are the institutional investors such as investment funds, mutual funds already receive trade reports on $\mathrm{T}+0$. On the other hand, Takasbank has started up a project called "SWIFT Integration Process to RTGS Model 1 DvP settlement" in order to establish a system which the custodian banks and brokerage houses can receive the confirmation messages from each other on $\mathrm{T}+1$. 
- Regarding recommendation 4, benefits of introducing a CCP mechanism, Takasbank has already started a project in coordination with the ISE for serving as a CCP for equities traded at the ISE. On the other hand, Takasbank is a CCP for the derivatives 


\section{APPENDIX I: STRUCTURE OF THE FINANCIAL SySTEM}

\section{Financial institutions}

\section{Banks}

156. The financial system remains dominated by banks, and increasingly by the larger private banks (Table 2). ${ }^{22}$ Ten banks account for around 80 percent of total banking sector assets. There is also a fringe of small specialized institutions.

157. The two major banks in state ownership (of which one is scheduled to be privatized) account for around 30 percent of banking sector assets. They still enjoy certain limited privileges, which are being phased out, and benefit from extensive branch networks. "Duty losses," that is, quasi-fiscal costs of subsidized loans, have been written off, and the banks are operating on a commercial basis, although their assets still include large amounts of high-earning non-marketable government securities. One bank is under the control of charitable foundations and thus can be considered public sector. The one bank remaining under the control of the SDIF is being used as a "bridge bank" in asset realization operations. Foreign interest in the banking sector is reviving strongly, as evidence by the wave of take-overs and new partnership arrangements at favorable valuations of Turkish banks.

158. Among the smaller banks are four "participation banks" that operate on the basis of risk and profit sharing. They have been enjoying especially strong growth and attracting new capital, including from abroad. Because they do not invest in (interest bearing) government securities, their assets are dominated by investments in the private sector; they report no shortage of suitable investment opportunities. ${ }^{23}$ They are subject to the same regulations as apply to other banks, and are eligible for deposit insurance as regards their sight deposits.

159. Access to finance is growing with stabilization and the banks' recovery from the 2001 crisis. There is intense competition for corporate business and household business in urban areas. Banks have also expanded their deposit taking activities, in part through electronic banking and ATMs, where Turkey ranks fairly high in Europe, but also in the numbers of bank branches compared to 2002.

160. Bank loans have recovered from 18 percent of GDP in $\mathbf{2 0 0 2}$ after the crisis to about 30 percent currently. Although the ratio of total credit to GDP is only now

\footnotetext{
${ }^{22}$ The table includes some double counting, because bank assets include claims on their NBFI subsidiaries. Agricultural credit cooperatives are excluded.

${ }^{23}$ Banks operating according to similar principles in other countries often complain that the available funding exceeds the supply of bankable projects.
} 
surpassing the level seen before the 2001 crisis, the composition has changed. Major growth areas have been credit cards and housing loans, which together account for over 20 percent of lending, compared to only 8 percent in 2002. Within commercial lending, SMEs account for about 50 percent of the total, compared to 48 percent in 2002 . However, agricultural lending has fallen to only 5 percent of bank lending, reflecting the post-crisis fall in agricultural lending by the state banks and the Agricultural Credit Cooperatives that traditionally depended on them for subsidized funding. ${ }^{24}$

161. Many major banks have overseas subsidiaries and offshore operations. Offshore lending to the Turkish nonfinancial sector amounts to about one tenth of total bank lending. Stamp duties, previously an important reason for locating offshore, have been eliminated. However, there is still BITT at 5 percent of the receipts of financial institutions, as well as a RUSF, which applies a charge of at 3 or 10 percent to interest receipts and certain loans (depending on whether they are commercial or consumer credits). ${ }^{25}$ The overwhelming part of this overseas business is conducted through branches of Turkish banks, which consolidate their accounts, and there are arrangements in place between the BRSA and many overseas supervisors. ${ }^{26}$ Also, banks are restricted by the BRSA as to how much of their total business for Turkish residents they can conduct offshore.

\section{Nonbank financial institutions}

\section{The main NBFIs are insurance companies and pension companies, and leasing and factoring firms, but together they constitute only about 13 percent of the system. In addition, there are financial service providers without significant own-assets such as securities firms and asset management companies. Many NBFIs are affiliated with banks, which also have connections to nonfinancial corporations.}

163. Most insurance companies are affiliates of banks, which creates opportunities for bancassurance. Foreign companies with global operations are increasing their presence in the local insurance market. Insurance distribution channels are dominated by agents, although brokers also play a big part in insuring large risks. Reinsurance is mostly used for large risks. The 20 percent cession to Millie Re (the formerly state-owned reinsurance company) was terminated in 2006, allowing the reinsurance market to operate free of compulsory cessions. Eighteen companies have exited the market in the past five years

\footnotetext{
${ }^{24}$ After the crisis, the large volume of bad loans of these institutions was written off and replaced by government debt. New lending by these institutions was put on a commercial basis and the government announced it would no longer order across- the-board write-downs of agricultural loans. These institutions still account for about 90 percent of agricultural lending.

${ }^{25}$ The authorities have in principle agreed to eliminate them, but would need to find offsetting fiscal measures. The BITT raises 0.5 percent of GDP and the RUSF 0.3 percent of GDP.

${ }^{26}$ Offshore lending to the Turkish nonfinancial sector is included in supervisory data but not in monetary data, which is on a residency basis. This distinction creates statistical non-comparabilities across sources.
} 
through license suspension or termination, or liquidation or bankruptcy. The Guarantee Fund has been used to settle a large number of motor claims. Several small companies that specialize in motor insurance and faced financial difficulties have been taken over by stronger domestic or foreign companies.

164. The new pension companies have experienced impressive growth. Their assets reached nearly YTL 2 billion in August 2006 ( 0.5 percent of GDP), less than 3 years after their launch. They cover almost 1 million participants. Contributions and investment returns benefit from modest tax incentives while withdrawals are less heavily taxed if they occur after reaching retirement age. The Central Register Agency, which keeps the records of all dematerialized securities, provides safe custody of the assets of pension mutual funds, which are segregated from those of the life and pension companies that manage them. The creation of the Pension Monitoring Center, a highly computerized system that is jointly-owned by the Treasury and the authorized pension companies, has enhanced the effectiveness of supervision.

165. Leasing firms raise their funds from banks, which are prohibited from engaging directly in leasing. Since 2000, leasing has tripled in dollar terms, to over US\$4 billion in leases. The average lease is about US\$100,000, and 75 percent of leases are for machinery and equipment. Changes in taxation could be considered to facilitate new types of leasing, such as operational leases.

\section{Securities markets}

166. Government debt is the most important category of securities traded in Turkish financial markets. Gross domestic government debt was slightly over 50 percent of GNP at end-2005, mostly in the form of bonds, with less than a tenth in bills. The turnover ratios in 2005 were 309 percent for bonds and 432 percent for bills. As of December 2005, the average maturity of the outstanding debt stock was just under two years, with 43 percent carrying variable rates, 41 percent in domestic currency with fixed rates, and 16 percent linked to or denominated in foreign currency.

167. The Treasury has been actively extending the duration and maturity of its debt, but banks - the main investor class - strongly prefer shorter-duration instruments, such as floating rate notes. Retail participation has declined from 22 percent in 2004 to 15 percent in 2005, probably because of increased competition from banking sector deposits and limited demand for new issues with maturities that exceed six months. The Treasury has successfully extended the maturity and duration of its external bonds at attractive levels relative to other emerging markets. As a consequence of the 20- and 30-year U.S. dollar bonds and 12-year Euro bonds issued in 2004 and 2005, the maturity (duration) of the external bond portfolio has increased from 5.4 years (3.4 years) at the end of 2003 to 8 years (4.9 years) as at end-2005.

168. The Turkish equity market is similar to that in other large emerging economies in terms of numbers of companies listed (306 at end-December 2005), market 
capitalization (40 percent of GDP), and turnover (155 percent of market capitalization in 2005). The market index (ISE-100) fell sharply during and after the crisis (from about 19,200 to 7,600 in September 2001), but has been rising since the end of 2003 and reached 47,000 in February 2006. Some companies have begun to raise funds in the market again and the number of listed companies has also begun to rise, after a few delistings during the crisis. August 2006 saw the first Turkish lira denominated corporate bond issue in a decade.

169. While legislation on housing finance will allow banks more flexibility in the design and securitization of mortgages, Turkey has had a relatively long history of using asset-backed securities (ABS). However, since 1995, impediments on the ability of banks to issue securities against their consumer loans have discouraged the issuance of ABS for these assets; some banks have issued ABS abroad based on their international receivables.

\section{Legislation and organization of regulation and supervision}

170. The independent BRSA was established in September 2000. Oversight of the SDIF, which both operates the deposit insurance scheme and acts as the bank resolution agency, was moved from the CBRT to the BRSA.

171. The CBRT Law was amended in 2001 to strengthen central bank independence and powers, and a new BL was passed in October 2005. The BL strengthens loan classification, loan loss provisioning and collateral valuation rules; introduces loan concentration exposure limits; tightens foreign exchange exposure rules; and establishes new rules for consolidation, risk management, fitness and propriety of owners and managers, and the exit of insolvent or illiquid banks. Prudential rules were extended to cover the state banks. New accounting standards were also introduced. Implementing regulations had to be issued within 12 months of the passage of the law, that is, by end-October 2006. New laws on mortgages and on credit card law were recently passed, and also the insurance supervision law is of recent vintage. 


\section{APPENDIX II: STRESS TeSTING: COVERAGE AND RESUlts}

\section{Overview}

172. Stress tests were carried out in the context of the FSAP with the aim of assessing the resilience of the banking system to key risks. This appendix describes the coverage of the tests, in terms of the sectors and institutions to which the tests were applied, and the main risks and vulnerabilities indicated by the exercise.

173. Stress tests were conducted at the consolidated level, for the banking sector, and for a set of major deposit taking banks. They covered the most important risk exposures of these institutions. ${ }^{27}$ The institutions participating in the bottom-up exercises comprised 9 banks, including 8 of the largest 9 banking groups, and encompassing over 80 percent of banking assets. The institutions used their own datasets and internal models, while applying the sensitivity test assumptions agreed between the authorities and the FSAP assessors.

174. The stress tests included sensitivity and scenario analyses. The exercises covered market risk, interest rate risk, credit risk, and liquidity risk, using sensitivity analysis. Scenario analysis assessed the impact of simultaneous, internally consistent changes to a group of macroeconomic variables on the financial position of banks. The effects of these shocks on the Turkish economy were simulated over a three-year window, with the help of the SPO's quarterly forecasting model. The shock calibrations for the sensitivity analyses were based on Turkey's historical experience of relatively high market and macroeconomic volatility, taking into account both statistical volatility measures of key market price variables and current market conditions. The selection of scenarios was based on events most likely to affect macroeconomic stability and growth given the current economic structure and conditions (for example, major changes in world energy prices, and unexpected reversals of capital flows away from emerging markets). ${ }^{28}$

175. Complementary exercises were carried out by the assessors using a combination of top-down and bottom-up approaches. ${ }^{29}$ Stress tests on selected sources of risk, and covering the banking system, were implemented using supervisory data and appropriately chosen models. These exercises included sensitivity analysis on market risk and credit risk, providing a way to generalize and cross-check the results obtained by the participating

\footnotetext{
${ }^{27}$ The banking system's assets constitute over 85 percent of the asset portfolio of the Turkish financial system, and for stress testing purposes, therefore, it sufficed to focus attention purely on this sector.

${ }^{28}$ Whereas the impact estimates of the shocks are instantaneous changes (or equivalent) in portfolio value, profits, and capital (using a 100 percent retained earnings assumption), for the scenarios, we project forward estimated deterioration in credit quality corresponding to the macroeconomic forecasts of the SPO model based on initial conditions as of end-2005 and the shocks specified in each scenario.

${ }^{29}$ Note that results obtained from the various approaches will never be fully comparable because they are based on different methodologies, data sets, and technical assumptions.
} 
institutions. The mission conducted a series of dynamic macro-stress tests combining dynamic panel models with scenario analysis to assess credit risk from exposures to the domestic market, broadly clustered into corporate and retail exposures.

176. While the results indicated low impact on solvency when applied to the sector's consolidated portfolio, the estimated impact of protracted interest rate and credit shocks on individual banks is quite large. The limited impact on solvency at the consolidated level reflects a combination of factors, most importantly the fairly comfortable capital buffers, particularly of the state-owned banks. The higher sensitivity to credit risk reported by the banks may reflect their superior databases and hence, better estimates of embedded loan portfolio risk.

\section{Sensitivity analysis}

177. Top-down stress tests revealed the sector to be resilient to the majority of market price shocks simulated in the exercise (Table 9). Large negative repricing gaps at the short end yield a severe impact of upward yield curve movements on profitability, albeit a substantial resolution of these gaps within the first 12 months following the shock. Again the sector's high initial capital level limits the impact on solvency. Exchange rate movements exercise negligible impact owing to the sector's almost closed position in foreign exchange.

Table 9. Selected Results of the Top-down Market Risk Stress Tests

\begin{tabular}{|c|c|c|c|c|}
\hline \multirow[t]{2}{*}{ Risk factor } & \multirow[t]{2}{*}{ Magnitude of shock } & $\begin{array}{l}\text { Impact on end-2005 } \\
\text { after-tax profits }\end{array}$ & $\begin{array}{l}\text { Impact on end-2005 } \\
\text { regulatory capital }\end{array}$ & $\begin{array}{l}\text { Post-Shock } \\
\text { CAR }\end{array}$ \\
\hline & & \multicolumn{3}{|c|}{ (In percentage points) } \\
\hline \multicolumn{5}{|l|}{$\begin{array}{l}\text { System CAR before shocks was } 22.9 \text { percent } \\
\text { Interest Rate Risk } 1 /\end{array}$} \\
\hline Interest rate increase; Parallel & YTL: 400 bps; Non-YTL: 300 bps & -70.2 & -17.2 & 18.8 \\
\hline Interest rate increase; Parallel & YTL: 1500 bps; Non-YTL: 1000 bps & -231.4 & -32.9 & 15.2 \\
\hline Interest rate increase; Positive tilt (short; long) & $\begin{array}{l}\text { YTL: (400 bps; } 1500 \text { bps) and } \\
\text { Non-YTL: (300 bps; } 1000 \text { bps) }\end{array}$ & -72.7 & -17.4 & 18.7 \\
\hline Interest rate increase; Negative tilt (short; long) & $\begin{array}{l}\text { YTL: (1500 bps; } 400 \text { bps) and } \\
\text { Non-YTL: (1000 bps; } 300 \text { bps) }\end{array}$ & -229.2 & -32.7 & 15.3 \\
\hline \multicolumn{5}{|l|}{ Exchange Rate Risk } \\
\hline Depreciation; Mild & -15 percent & -0.4 & 0.0 & 20.4 \\
\hline Depreciation; Strong & -45 percent & -1.3 & -0.1 & 20.4 \\
\hline Appreciation; Mild & 15 percent & 0.4 & 0.1 & 20.5 \\
\hline Appreciation; Strong & 45 percent & 1.3 & 0.1 & 20.5 \\
\hline \multicolumn{5}{|l|}{ Market Risk } \\
\hline $\begin{array}{l}\text { Combined shock 1/ } \\
\text { Interest rate increase; Positive tilt } \\
\text { and Depreciation; Strong }\end{array}$ & & -74.1 & -7.2 & 21.1 \\
\hline $\begin{array}{l}\text { Combined shock } 2 \\
\text { Interest rate increase; Negative tilt } \\
\text { and Depreciation; Strong }\end{array}$ & & -230.6 & -22.4 & 17.6 \\
\hline
\end{tabular}


178. Market risk stress tests implemented by the banks yielded qualitatively similar results, with the majority of shocks impinging substantially on profits but not on capital, albeit with some notable differences (Table 10). On average, participating institutions reported a greater sensitivity to market price movements through their selfassessments than the assessors' analysis at the sectoral level. More strikingly, however, there was a wide variation in the impact estimates reported by the banks. Large yield curve increases, either in combination with exchange rate depreciation, or on their own resulted in notable capital impairment in a few banks.

179. The sensitivity of the value of the mark-to-market portfolio to combinations of interest and exchange rate shocks was low for most banks (Table 11). A majority of the participating credit institutions hold a large proportion of their foreign currency assets on the mark-to-market portfolio, implying that depreciations of the YTL lead to income gains that more than offset the (substantial) loss in market value forthcoming from increases in interest rates. However, as banks' net foreign currency positions are closed when considering the entire balance sheet exposures and off balance sheet positions, the interest rate channel dominates the income impact in the case of combined changes over time (as is shown by a comparison of Tables 10 and 11).

180. Exposure to liquidity risk appears to be small, although this hinges on the liquidity of the sovereign bond market, should conditions deteriorate for the entire system. Based on historical estimates of core deposits, the liquidity coverage for foreign exchange liabilities through liquid foreign exchange assets is superior for most banks than for the YTL portion of the balance sheet. This may be a reflection of the decrease in exchange rate and macroeconomic volatility after the 2001 crisis.

181. Deterioration in credit quality exercises a substantial impact on profits and on regulatory capital (Table 12). Sensitivity analysis performed by the banks, based on increases in the probabilities of default (PDs), over the entire loan portfolio by 200 percent, and separately over the corporate loan portfolio by 400 percent from their end-2005 levels, indicated that about half of the participating institutions would miss the target of 12 percent minimum CAR, although almost all the CARs remain above the lower regulatory threshold of 8 percent. Estimates by the participating credit institutions produced average losses of 11 percent and 8 percent respectively, of regulatory capital.

182. Complementary credit risk stress tests implemented by the assessors for the system yielded substantially lower estimates of capital reduction for the corporate portfolio shock. The exercise was based on a simulation that entailed a 400 percent increase in the PDs of all corporate sector loans and yielded a 4 percent reduction in regulatory capital with negligible impact on the system level CAR. These lower loss estimates may be largely explained by the nature and limitations of the database utilized, which only enabled an estimation of corporate sector PDs via default statistics beginning January 2002; i.e., over a period of time that containing an upswing — but not a downswing — of the business cycle. While an attempt was made to correct this by assuming higher losses-given-default (LGDs) as compared to the banks, this downward bias in the PD estimates continues to dominate. 


\section{Table 10. Selected Results of Stress Tests on Market, Interest Rate, and Exchange Rate Risk}

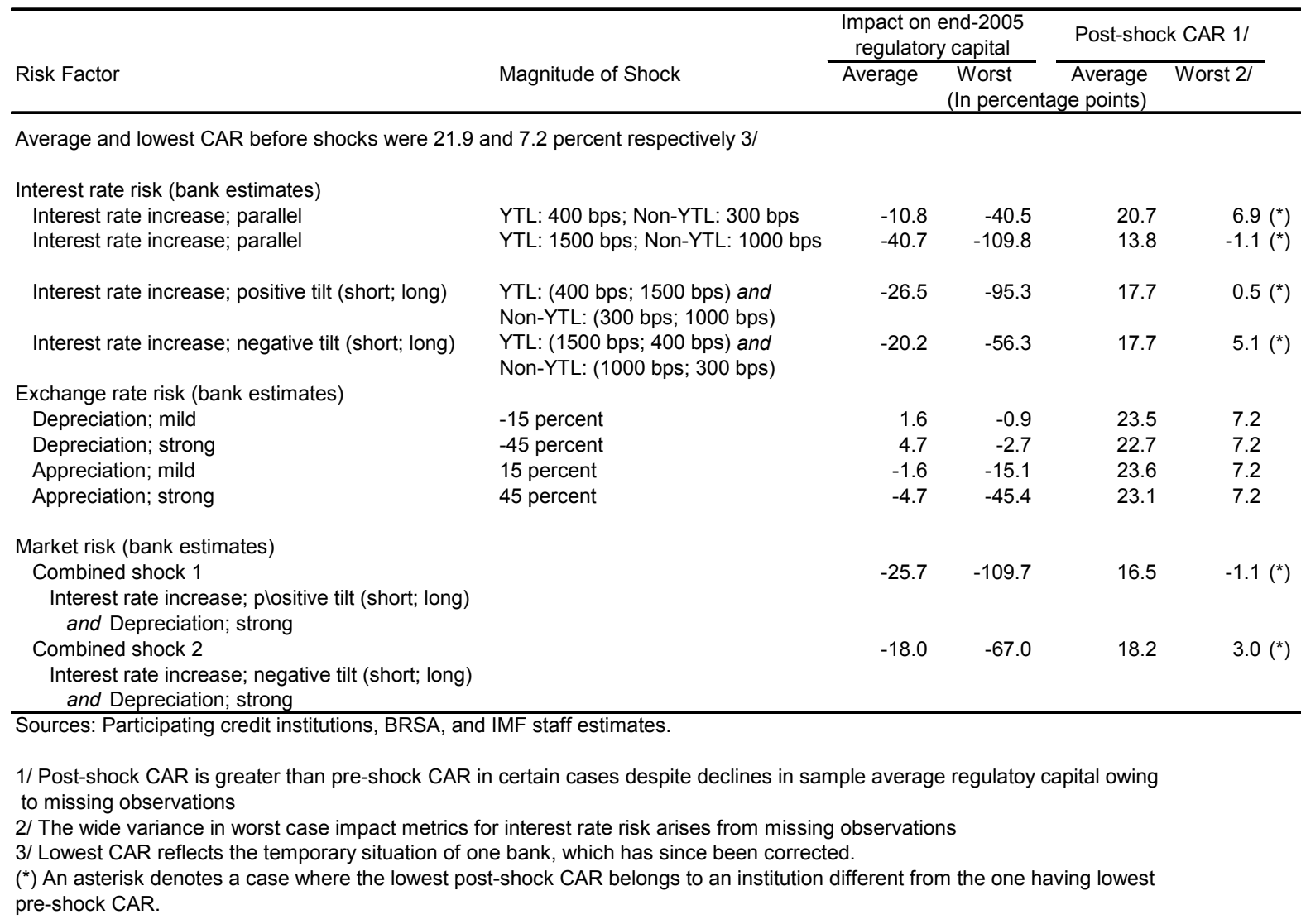




\section{Table 11. Market Risk Impact on Mark-to-Market Portfolio, Banks' Estimates, December 2005}

\begin{tabular}{|c|c|c|c|c|c|c|c|}
\hline \multirow[b]{2}{*}{ Risk factor } & \multirow[b]{2}{*}{ Magnitude of Shock } & \multicolumn{2}{|c|}{$\begin{array}{l}\text { Impact on end-2005 } \\
\text { after-tax profits }\end{array}$} & \multicolumn{2}{|c|}{$\begin{array}{l}\text { Impact on end-2005 } \\
\text { regulatory capital }\end{array}$} & \multicolumn{2}{|c|}{ Post-shock CAR 1/ } \\
\hline & & Average & Worst & $\begin{array}{l}\text { Average } \\
\text { (In percentag }\end{array}$ & $\begin{array}{l}\text { Worst } \\
\text { ge points) }\end{array}$ & Average & Worst \\
\hline \multicolumn{8}{|c|}{ Average and Worst CAR before shocks were 21.9 and 7.2 percent respectively 2 / } \\
\hline \multicolumn{8}{|l|}{ Interest Rate Risk (Bank Estimates) } \\
\hline Interest rate increase; Parallel & YTL: 400 bps; Non-YTL: 300 bps & -23.0 & -36.3 & -5.7 & -8.8 & 21.2 & 6.9 \\
\hline Interest rate increase; Parallel & YTL: 1500 bps; Non-YTL: 1000 bps & -75.0 & -118.6 & -18.9 & -28.6 & 18.3 & 6.4 \\
\hline Interest rate increase; Positive tilt (short; long) & $\begin{array}{l}\text { YTL: (400 bps; } 1500 \text { bpsqnd } \\
\text { Non-YTL: (300 bps; } 1000 \text { bps) }\end{array}$ & -49.4 & -76.6 & -12.5 & -18.5 & 19.7 & 6.4 \\
\hline Interest rate increase; Negative tilt (short; long) & $\begin{array}{l}\text { YTL: (1500 bps; } 400 \text { bpsqnd } \\
\text { Non-YTL: (1000 bps; } 300 \text { bps) }\end{array}$ & -50.3 & -83.1 & -12.7 & -20.0 & 19.7 & 6.9 \\
\hline \multicolumn{8}{|l|}{ Exchange Rate Risk (Bank Estimates) } \\
\hline Depreciation; Mild & -15 percent & 60.2 & 0.0 & 13.9 & 0.0 & 26.9 & 7.2 \\
\hline Depreciation; Strong & -45 percent & 180.6 & 0.0 & 41.8 & 0.0 & 33.5 & 7.2 \\
\hline Appreciation; Mild & 15 percent & -60.2 & -103.4 & -13.9 & -24.9 & 20.4 & 7.2 \\
\hline Appreciation; Strong & 45 percent & -180.6 & -310.1 & -41.8 & -74.7 & 13.8 & 5.4 \\
\hline \multicolumn{8}{|l|}{ Market Risk (Bank Estimates) } \\
\hline $\begin{array}{l}\text { Combined shock } 1 \\
\text { Interest rate increase; Positive tilt (short; long) } \\
\text { and Depreciation; Strong }\end{array}$ & & 109.4 & -65.3 & 26.2 & -12.5 & 29.7 & 8.0 \\
\hline $\begin{array}{l}\text { Combined shock } 2 \\
\text { Interest rate increase; Negative tilt (short; long) }\end{array}$ & and Depreciaiton: Strong & 111.0 & -55.4 & 27.3 & -10.6 & 30.0 & 8.7 \\
\hline
\end{tabular}

\section{Table 12. Sensitivity Analysis Estimates of Credit Risk, December 2005 (Bank estimates)}

\begin{tabular}{|c|c|c|c|c|c|}
\hline \multirow[b]{2}{*}{ Magnitude of Shock } & \multicolumn{2}{|c|}{$\begin{array}{c}\text { Impact on end-2005 after- } \\
\text { tax profits } 1 / \\
\end{array}$} & \multicolumn{2}{|c|}{$\begin{array}{l}\text { Impact on end-2005 } \\
\text { regulatory capital } 2 /\end{array}$} & $\begin{array}{c}\text { Post-shock } \\
\text { CAR 3/ }\end{array}$ \\
\hline & Average & Worst & $\begin{array}{l}\text { Average } \\
\text { ercentage }\end{array}$ & $\begin{array}{l}\text { Worst } \\
\text { ints) }\end{array}$ & Average Worst \\
\hline
\end{tabular}

Average and Worst CAR before shocks were 21.9 and 7.2 percent respectively $4 /$

1. Global Credit Portfolio Shock

PDs on each loan increases by 200 percent

$-51.6$

$15.2 \quad 5.3$

2. Corporate Credit Shock

PDs on each corporate loan increases by 400 percent

$-213.5$

$-8.0$

$-56.1$

$15.45 .5\left({ }^{*}\right)$

3. Shift of risk characteristics in corporate loan portfolio

Downgrade by one notch of all loans (IR scale) $-11.2$ $-15.6$ $-2.4$ $-3.7$ $19.7 \quad 12.2\left(^{*}\right)$ Sources: Participating Credit Institutions, BRSA, and FSAP Calculations.

Notes: Impacts are weighted averages across the sample of banks for each shock

$1 /$ Expected losses are added to general provisions and hence, reported as a percentage decrease in after tax 2005 profits.

2/ Taken to mean the expected reduction in capital should the expected loss occur

3 / Post-shock CAR is greater than pre-shock CAR in certain cases despite declines in sample average regulatory capital owing to missing observations.

4/ Lowest CAR reflects the temporary situation of one bank, which has since been corrected.

(*) An asterisk denotes a case where the lowest post-shock CAR belongs to an institution different from the one having the lowest pre-shock CAR.

\section{Macroeconomic scenario analysis}


183. Four macroeconomic scenarios were considered, taking into account the main risk factors and exposures of Turkey's financial system. They were: (i) a permanent increase in oil prices to US\$140 per barrel; (ii) a fiscal slippage scenario; (iii) a boom-bust scenario, wherein growth over the first four quarters succeeding end-2005 exceeds expected levels, but declines dramatically thereafter; and (iv) a zero net capital inflow scenario. In particular the first and fourth scenarios represent very large and persistent deteriorations in economic performance.

\section{A complete cessation of capital inflows into Turkey represents a major risk to} the banking sector through a deterioration in the quality of banks' credit books (Table 13). Dynamic macroeconomic analysis over a 12 quarter horizon was used to forecast the impact of a no-inflows scenario on GDP growth, unemployment, domestic prices, and exchange and relevant interest rates. The economic contraction results in a rapid increase in non-performing loans, generating cumulative losses in banking capital estimated at almost 40 percent relative to end-2005 levels, which could reduce average CAR by 9 percentage points in the absence of management action. A number of banks, including some medium-sized ones, are likely to require substantial injection of fresh capital from shareholders for them to meet CAR thresholds in the event of such a very severe economic downturn.

\section{Sustained and large increases in oil prices also exercise a significant negative} effect on the banking industry. Although the impact is not estimated to be as large as in the case of the sudden stop episode, mainly owing to lower sensitivity of key macroeconomic variables to this exogenous shock, capital reductions could still reach 20 percent by end2008. At a sectoral level, CAR is likely to comfortably exceed the regulatory 12 percent threshold, albeit with certain individual institutions requiring fresh injections of capital. 
Table 13. Impact of Scenarios on Banking Sector Capital, 2005-2008

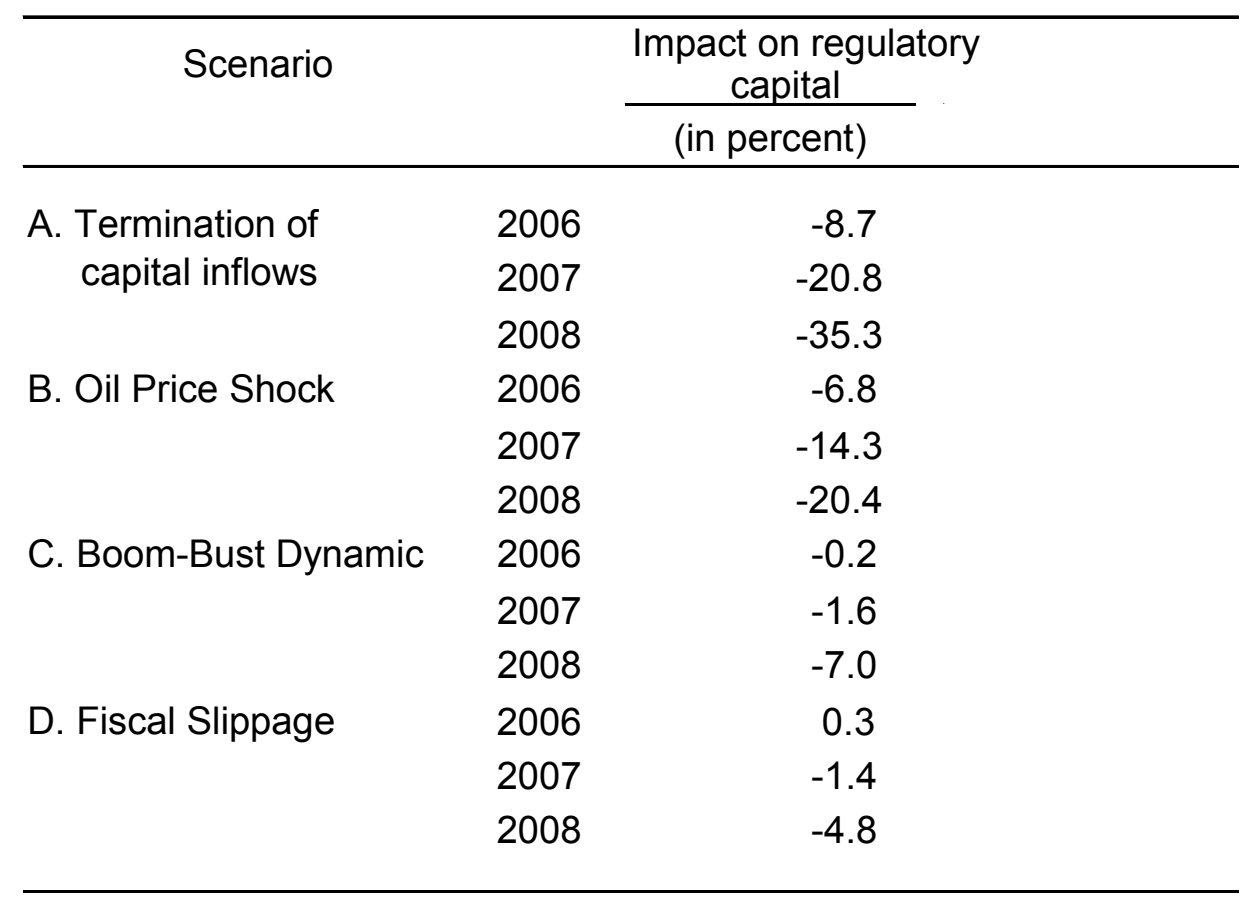

Sources: FSAP estimates.

1/ On an end-of-period basis. 